Historic, Archive Document

Do not assume content reflects current scientific knowledge, policies, or practices. 


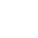




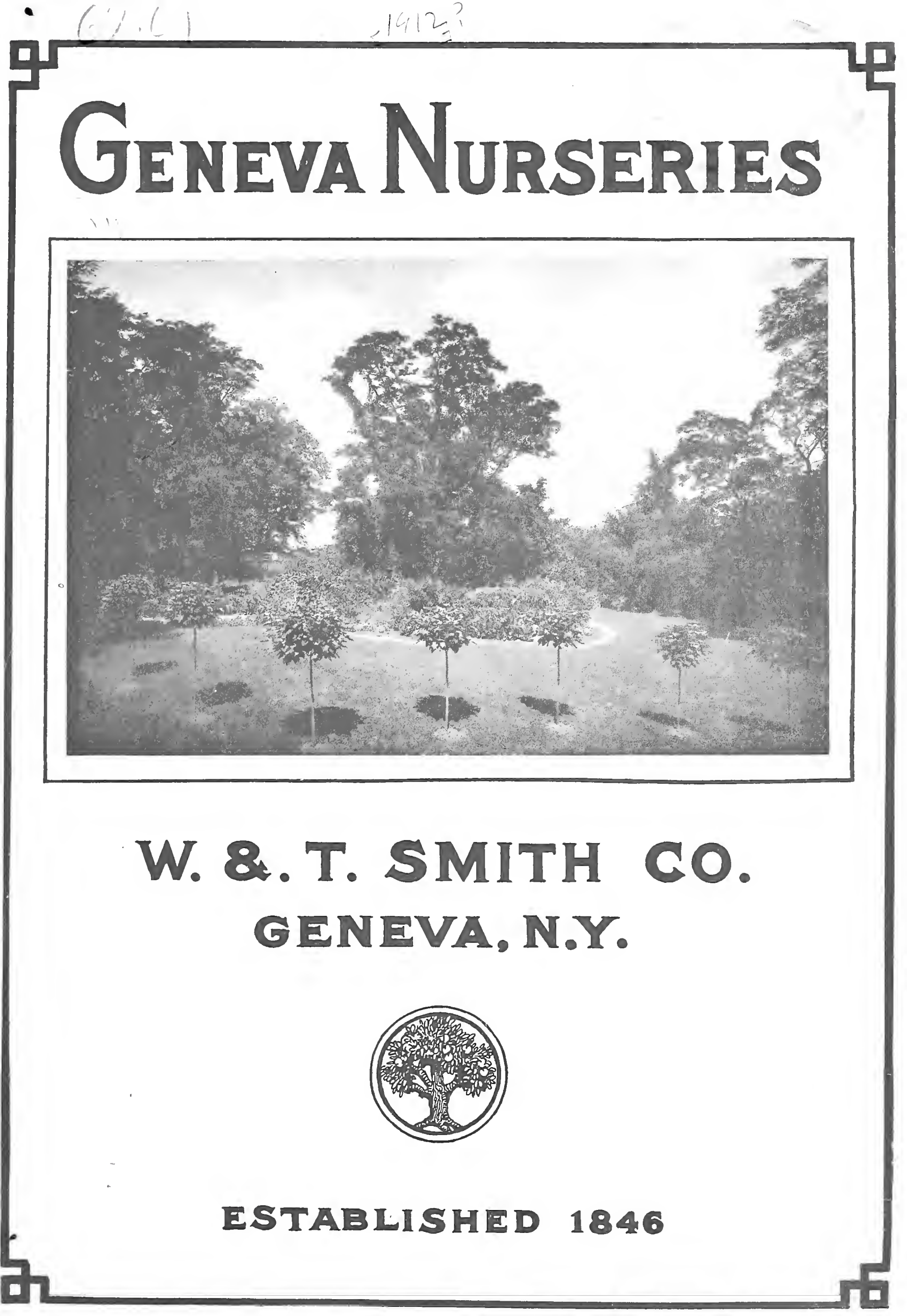




\section{Notice to Customers}

I. Orders should be sent in as early as possible, that there may be plenty of time for shipping long distances when necessary.

2. Buyers, ordering by letter, should write out their order plainly, on a separate list, and not in the body of the letter. It will prevent mistakes in the hurry of the packing season.

3. Give plain and explicit shipping directions. When none are given we forward according to our best judgment; but in no case do we assume any responsibility after the delivery of the stock in good condition to the forwarder.

4. All orders from unknown correspondents must be accompanied with the cash or satisfactory references.

5. If the varieties of fruit ordered cannot be supplied, others equally as good and ripening about the same season, will be substituted, unless ordered to the contrary.

6. We recommend that purchasers leave the selection of varieties with us, as far as possible, merely stating the proportion of summer, fall and winter fruit wanted, as our experience enables us to select such sorts as are adapted to the locality.

7. Immediate notice should be given to us of any error in filling out an order so that we may at once rectify the mistake or give a satisfactory explanation.

\section{Low Express Rates on Trees and Plants}

Express companies now carry trees and plants to any part of the country at a reduction of 20 per cent. from regular merchandise rates.

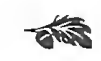

\section{Fumigation and Inspection}

Our nurseries are inspected twice each year by the State Entomologist, and are lept free from all insects and pests, but in order to insure our patrons that everything is perfectly free from scale, pests, etc., we will on request fumigate any goods shipped to them. 


\section{Introduction}

It is hardly necessary for us, in presenting this new and revised edition of our General Catalogue, to devote much space to introduction.

For more than sixty-five years, The "Geneva Nurserx" has been before the public, as an acknowledged leader among the great nursery concerns of the world, and we are privileged to say, that the experienced management which has characterized it from its beginning, and the unsurpassed facilities for growing and handling stock which it possesses, enables it still to hold that position.

We have used every means to keep in the lead in introducing new varieties, and as soon as their value is established they are offered to our patrons with a candid statement as to their worth.

We believe we stand at the head among nurseries of the country in the matter of growing every plant suitable for this climate, and we have in our employ such a force of skilled assistants that we are in a position to assure our patrons that their orders will be carefully and correctly filled.

We offer and accept orders for only such varieties as we can supply. If, through any oversight in filling orders, mistakes may occur, purchase money will be refunded or other stock will be furnished in lieu thereof.

We aim to supply only the best of stock, and at the lowest prices consistent with the quality of goods offered.

We wish to thank the public for the liberal patronage which it has given us for more than half a century, and solicit a continuance of the same.

We extend an invitation to our patrons to visit our nurseries and see for themselves the extent of our plant and study our methods.

\section{OUR LOCATION AND ADVANTAGES}

OUR Locatiox, being in the most delightful and fertile-growing region in the State of New York, gives us facilities for growing nursery stock equaled by few, and surpassed by none; it is easy of access to all parts of the country in the shipping and transportation of trees.

Our land contains all the mineral elements needed to produce THE HARDIEsT, HEALTHIEST and THRIFTIEST TREES, those which are the longest lived, and which will produce THE BEST POSSIBLE REsults for the planter. For these reasons we claim great advantages from our soil. This is a matter of the GREATEST IMPORTANCE TO EVERY planter. It PAYS to produce THE BEST and THAT "ONLY." It is one of the first laws of Nature, that in order to obtain the BEST, we MUST have the BEST to produce from.

A very important feature in connection with our trees is that grown upon our HEAVY, STRONG, RICH, well-drained soil, they are healthier, longer-lived, less liable to injury from extreme cold, and more productive than when taken from a light soil, and that being furnished with a more abundant supply of HEALTHY, WELL-RIPENED and FIBROUS ROOTS, they bear transplanting to a different soil and climate.

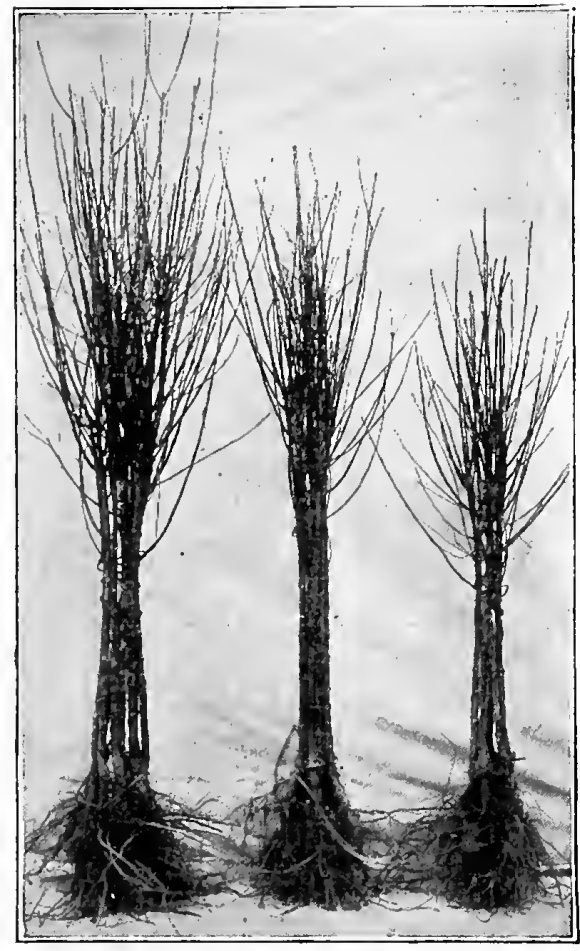

TREES AS THEY ARE RECEIVED FROM THE NURGERY.

\section{HINTS ON TRANSPLANTING, ETC.}

\section{The following points should never be overlooked:}

1st, Preparation of the Soil-Prepare a rich, deep bed of mellow soil, and have the land sufficiently drained to relieve the roots from standing water. To insure a fine growth, land should be in as good condition as is required for a crop of wheat, corn or potatoes.

2d, Pruning before Planting-Nearly all the Trees taken from the Nursery require pruning before transplanting, to balance the loss of roots occasioned by their removal. The tops should be shortened in by cutting off half the last season's growth of all the branches, but large branches should not be cut off close to the trunk, as it injures the vitality of the tree.

All broken or bruised roots should be cut off smoothly up to the sound wood, so as to hasten the emission of new roots and fibers.

3d, Planting-Make the holes large enough to admit the roots without any cramping or bending, and deep enough to bring the tree to its natural depth. The fine surface soil should be used in covering the roots, and this should be carefully worked among them. If the ground is dry, it is well to pour in some water when the hole is partially filled. See that the ground is firmly and solidly packed over all parts of the roots by exerting the full weight of the planter upon it, so that there will be no opportunity for dry air or frost to enter and destroy roots deprived of the full benefit of their natural protection. Omission to pack the earth solidly is a most frequent cause of failure in planting nursery stock. Fill the holes full enough to be even with the surrounding surface after the fresh earth settles. Always remove the label when planting. If this is left until the tree is grown, the connecting wire often cuts into and destroys the tree or branch to which it is attached. Never use manure in contact with roots. When planting dwarf trees set them low enough to cover the stock upon which they are budded, but not lower. Large standard trees should be staked and tied, so that the wind will not loosen the roots. This should be so done that the bands will not chafe the trees. 
4th, Mulching.- When trees or bushes are planted, they should be mulched or covered with a layer of coarse manure or litter from three to six inches deep for a space of say two feet more in diameter than the extent of the roots. This keeps the earth moist and of even temperature.

5th, After Culture. Grass should not be allowed to grow about young trees or plants. The ground should be cultivated for a space of at least one foot outside the roots. If the ground is poor it should be enriched with surface applications of manure. Pruning should be varied according to the condition of the tree, and the purpose of the planter. It should be done regularly every spring, before the buds swell any. In this way the removal of large branches will be avoided.

\section{DISTANCES FOR PLANTING}

Standard Apples ....................30 feet apart each way Standard Pears and Strong Growing Cherries. 20 Duke and Morello Cherries ...............18 Standard Plums, Apricots, Peaches, Nectarines. 16 Dwarf Pears ................... 8 to 10 Quinces.......................................... 12 Blackberries .................6 to 7 Currants, Gooseberries and Raspberries .. 4 Strawberries ................ $11 / 2$ to 2

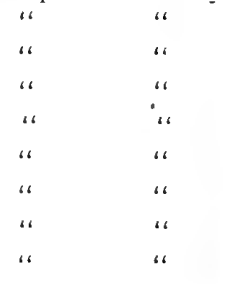

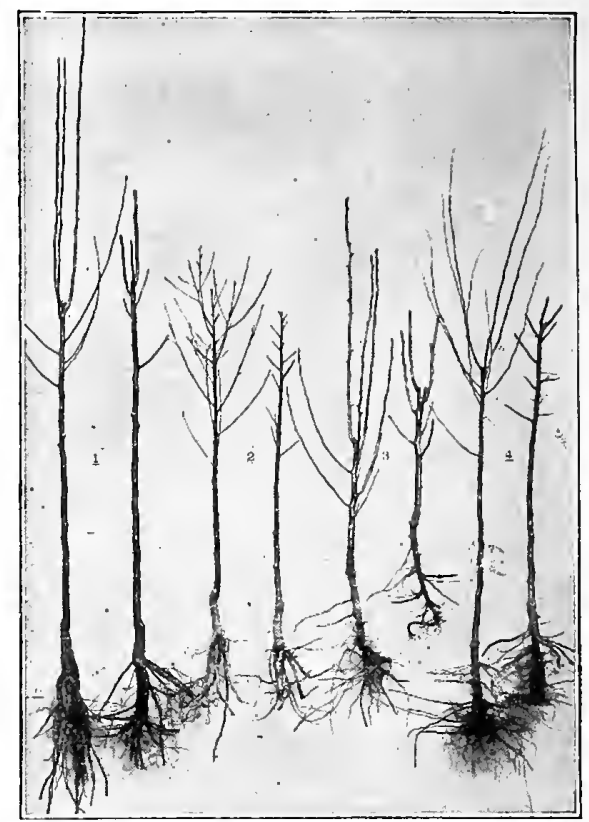

\section{DISTANCES FOR PLANTING HEDGE PLANTS} Arbor Vitæ, Siberian ............ 12 to 15 in. apart 9 to 12

Dwarf Box, for edging.
12 to 15 4

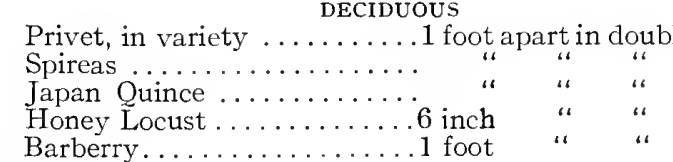

Privet, in variety $\ldots \ldots \ldots \ldots 1$ foot apart in double rows Japan Quince

Barberry. ... PROM THE NURSERY AND AFTER BEING PRUNED
POR PLANTING. I KIEFPER PEAR: 2 PEACH; 3 DWARF DUCHESS, 4 QUINCE.

\section{SPRAYING}

Spraying has come to be an established part of fruit-growing. With all that has been written upon the subject, the fruit-grower should be competent to perform the ordinary spraying of his trees without further advice: but to those who may not be familiar with the methods and practice, we would say, procure a copy of Bulletin No. 101 by Prof. L. H. Bailey, from the Cornell University Experiment Station, in which will be found the most important points regarding sprays, arranged in such a manner that the grower can see at a glance what to apply, when and how to make the applications.

\section{HOME MADE LIME SULPHUR*}

Lime. Use only fresh lump lime free from dust or from partly air slaked lumps. No air slaked lime should be used. The lime should test not less than 90 per cent. pure lime (calcium oxide) and should not contain more than 5 per cent. inagnesium oxide.

Sulphur. Either flowers of sulphur or light or heavy sulphur flour may be used.

FORMULA AND DIRECTIONS:

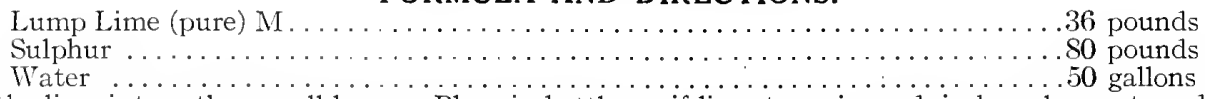

"Break the lime into rather small lumps. Place in kettle, or if live steam is used, in barrel or vat, and slake it with hot water. Make a smooth paste of the sulphur with water. Add this to the lime as slaking commences, and mix thoroughly. When the lime is all slaked, add the rest of the 50 gallons of water, and enough more as needed from time to time during the boiling to keep the quantity up to 50 gallons. When steam is used for cooking, extra water may not be needed. Use a measuring stick notched at the 50 gallon mark to show how much water needs to be added to keep the volume up to 50 gallons. Do not let it drop more than an inch below the 50 gallon mark at any time. Dash a little cold water into the kettle to stop the boiling for a moment while measuring. Keep well stirred to break up lump, and prevent caking on the sides of the kettle. Boil vigorously from 45 minutes to one hour, or till the sulphur is all dissolved. Use a kettle of sufficient capacity to prevent loss from boiling.

When through with the boiling bring the volume up to 50 gallons and strain it without trying to separate it from the finer sediment which passes through the sieve. The coarse particles which do not go through the strainer are kept for later boilings."

\section{PREPARATION OF SELF-BOILED LIME SULPHUR}

The 8-8-50 formula is recommended. This mixture can best be prepared in rather large quantities-say enough for 200 gallons at a time, making the formula 32 pounds of lime and 32 pounds of sulphur to be cooked with 8 or 10 gallons of water, and then diluted to 200 gallons.

"The lime should be placed in a barrel and enough water poured on to almost cover it. As soon as the lime begins to slake the sulphur should be added first, after running it through a sieve to break up the lumps. The mixture should be constantly stirred and more water added as needed to form a thick paste at first, and then gradually a thin paste. 
The lime will supply enough heat to boil the mixture several minutes. As soon as it is well slaked, water should be added to cool the mixture and prevent further cooking. It is then ready to be strained into the spray tank, diluted and applied.

"The stage at which cold water should be poured on to stop the cooking varies with different limes. Some limes are so sluggish in slaking that it is difficult to obtain enough heat from them to cook the mixture at all, while other limes bccome intensely hot on slaking and care must be taken not to allow the boiling to proceed too far. If the mixture is allowed to remain hot fifteen or twenty minutes after the slaking is completed, the sulphur goes into solution, combining with the lime to form sulphides, which are injurious to peach foliage. It is very important, cspecially with hot lime, to cool the mixture quickly by adding a few buckets of water as soon as the lumps of lime have slaked down. The intense heat, violent boiling, and constant stirring result in a uniform mixture of finely divided sulphur and lime, with only a very small percentage of the sulphur in solution. This mixture should be strained to take out the coarse particles of lime, but the sulphur should be carefully worked through the strainer."

Dilutions for Dormant and Summer Spraying with Lime-Sulphur Mixtures*

\begin{tabular}{|c|c|c|c|c|c|c|c|}
\hline \multirow[b]{3}{*}{ Degrees of Beaumé } & \multicolumn{3}{|c|}{$\begin{array}{l}\text { Amount of dilution } \\
\text { Number of gallons of water to one } \\
\text { gallon of lime-sulphur solution }\end{array}$} & & $\begin{array}{r}\text { Am } \\
\text { Number of } g \\
\text { gallon of } 1\end{array}$ & $\begin{array}{l}\text { lount of } \\
\text { allons of } \\
\text { me-sulph }\end{array}$ & $\begin{array}{l}\text { dilution } \\
\text { water to one } \\
\text { uur solution }\end{array}$ \\
\hline & $\begin{array}{l}\text { For } \\
\text { San José } \\
\text { scale }\end{array}$ & $\begin{array}{l}\text { For } \\
\text { blister } \\
\text { mite }\end{array}$ & $\begin{array}{l}\text { For summer } \\
\text { spraying of } \\
\text { apples }\end{array}$ & Reading of hydrometer & $\begin{array}{l}\text { For } \\
\text { San José } \\
\text { scale }\end{array}$ & $\begin{array}{l}\text { For } \\
\text { blister- } \\
\text { mite }\end{array}$ & $\begin{array}{l}\text { For summer } \\
\text { spraying of } \\
\text { apples }\end{array}$ \\
\hline & 9 & $121 / 2$ & 45 & $\begin{array}{l}\text { Degrees Beaumé } \\
\ldots\end{array}$ & 5 & 7 & 26 \\
\hline & $83 / 4$ & 12 & $431 / 4$ & 23 . & $41 / 2$ & $6 \mathrm{r} / 2$ & $24 \mathrm{I} / 4$ \\
\hline & $81 / 4$ & $11 \frac{1}{2}$ & $411 / 2$ & 22 . & $41 / 4$ & 6 & $223 / 4$ \\
\hline & 8 & 11 & $40^{\prime}$ & 21. & $33 / 4$ & $5 \mathrm{I} / 2$ & $211 / 4$ \\
\hline & $71 / 2$ & $101 / 2$ & $373 / 4$ & 20 . & $31 / 2$ & 5 & $193 / 4$ \\
\hline & $71 / 4$ & 10 & $361 / 4$ & 19. & $31 / 4$ & $43 / 4$ & $181 / 4$ \\
\hline & $63 / 4$ & $91 / 2$ & $341 / 4$ & 18. & & $41 / 4$ & 17 \\
\hline 28 & $61 / 2$ & 9 & $323 / 4$ & 17 & $23 / 4$ & 4 & 16 \\
\hline & 6 & $81 / 2$ & 31 & 16. & $21 / 2$ & $33 / 4$ & 15 \\
\hline & $53 / 4$ & 8 & $291 / 2$ & 15 & $21 / 4$ & $3 \mathrm{r}$ & 14 \\
\hline & $51 / 4$ & $71 / 2$ & $273 / 4$ & 14. & 2 & 3 & $123 / 4$ \\
\hline
\end{tabular}

\section{ARSENATE OF LEAD}

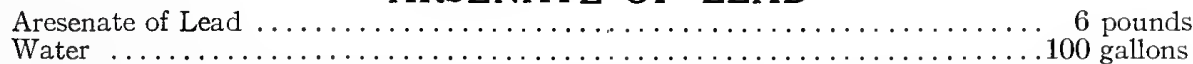

It is better to purchase arsenate of lead than to attempt to make it. In mixing, preparatory to spraying, the amount of arsenate of lead for each spray tank full should be worked into a very thin paste having the appearance of milk of lime. It should never be thrown as a mass into the spray tank. This is a standard spray for codling moth and other eating insects. It is possible, however, that we shall use arsenite of zinc in the future.

\section{KEROSENE EMULSION}

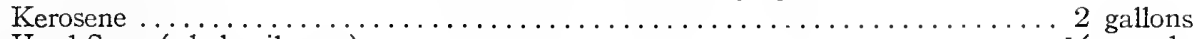

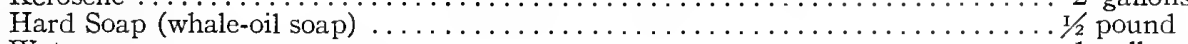

Water ................. 1 gallon

Dissolve soap in water by boiling; add hot suds to the kerosene. Do not do this near a fire. Agitate the mixture with a spray pump so as to emulsify the oil. After five minutes the mixture becomes creamy. To use, dilute the above stock solution at the rate of one gallon to ten gallons of water. This is a standard remedy for destroying green aphis, wooly aphis, mealy bugs and other plant lice. It may be used instead of the tobacco solutions if desired.

\section{CORROSIVE SUBLIMATE}

(Bichloride of Mercury)

This is the standard disinfectant when working with PEAR BLIGHT. No other disinfectant should be used to wash the cut surfaces or to disinfect the pruning tools.
Corrosive Sublimate

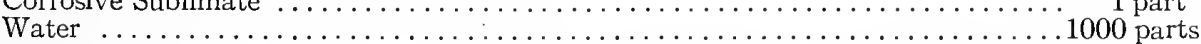

Corrosive sublimate may be purchased in tablet form at drug stores and directions for making solutions will be found on the container. Never put corrosive sublimate into a metallic container, always use a glass bottle. Be sure to label the bottle "Poison" in large, plain letters. It is the deadliest of poisons.

\section{WHITEWASHES $†$ \\ 1. Government Whitewash}

Lime (unslaked)................40 pounds

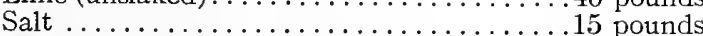

Rice Flour (or ground rice)................. 3 pounds

Spanish Whiting.............

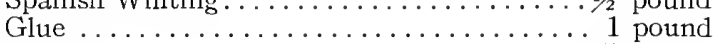

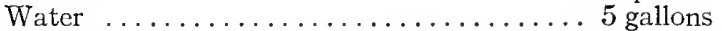

Slake the lime in warm water and cover so as to keep in the steam; strain through a fine sieve or strainer; add the salt, well dissolved in warm water. Then add the rice boiled hot; the Spanish whiting; and finally the glue which has been previously dissolved over a slow fire. Lastly, add the five gallons of hot water. Stir well and let stand for a few days. Apply hot with a brush. One pint of the mixture will cover a square yard. Coloring matter may be put in, such as Spanish brown, yellow ochre, etc.

\section{HOW TO SPRAY}

Drench every part of the tree. Spray thoroughly. The most difficult places to reach should receive your most careful attention. Reach every crack, calyx cup, behind buds and in bud scales. Do not economize on spray material and sacrifice efficiency. Use a high pressure pump. 200 pounds prcssure should be maintained. Spraying out of season is valueless. Determine what you must spray for. Use the right kind of material.

*Parrott \& Schoene, N. Y. State (Geneva) Bul. 330.

$\dagger 1912$ Spraying Calendar, Medford, Oregon. 


\section{SPRAY CALENDAR}

\begin{tabular}{|c|c|c|}
\hline WHAT TO SPRAY FOR & SPRAY TO USE & REMARKS \\
\hline $\begin{array}{l}\text { San Jose Scale } \\
\text { Scurfy Scale } \\
\text { Bud Moth } \\
\text { Eggs of Apple Aphis } \\
\text { Eggs of Red Spider } \\
\text { Green Peach Aphis } \\
\text { Oyster Shell Scale } \\
\text { Peach Leaf Curl } \\
\text { Pear Leaf Blister Mite }\end{array}$ & $\begin{array}{l}\text { Lime Sulfur } \\
\text { Winter strength }\end{array}$ & $\begin{array}{l}\text { Apply while buds are swelling to Apples, Pears, Peaches, Plums } \\
\text { and Cherries and small fruits, using the winter strength lime sulphur } \\
\text { drenching all parts of the tree. } \\
\text { Test both the commercial and homemade lime sulfur with hy- } \\
\text { drometer before using to secure the correct strength. The tree must } \\
\text { be completely covered with winter strength lime-sulfur when spraying } \\
\text { for scale insects. Coat every portion from ground to tip of twigs. }\end{array}$ \\
\hline Strawberry Leaf Blight & $\begin{array}{l}\text { Lime Sulfur } \\
\text { Summer strength }\end{array}$ & $\begin{array}{l}\text { Apply when new leaves start } \\
\text { Repeat cvery ro-I5 days until flowers appear. Burn leaves as soon } \\
\text { as crop is harvested. }\end{array}$ \\
\hline Thrips & 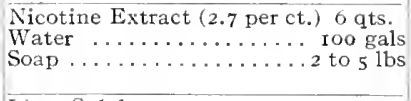 & $\begin{array}{l}\text { The period for effective spraying against the adult thrips, is during } \\
\text { the time when the buds are swollen and partly open, and until they are } \\
\text { entirely open at the tips. Spray for the larve after the petals drop to } \\
\text { reduce the numbers of insects for the following year. }\end{array}$ \\
\hline $\begin{array}{l}\text { Apple Scab } \\
\text { Black Rot of Applc } \\
\text { Brown Rot of Prune } \\
\text { Bud Moth } \\
\text { Caterpillars } \\
\text { Codling Moth }\end{array}$ & $\begin{array}{l}\text { Lime Sulpher } \\
\text { Summer strength } \\
\text { and } \\
\text { Arsenate of Lead } \\
3 \text { lbs. to } 50 \text { gallons }\end{array}$ & 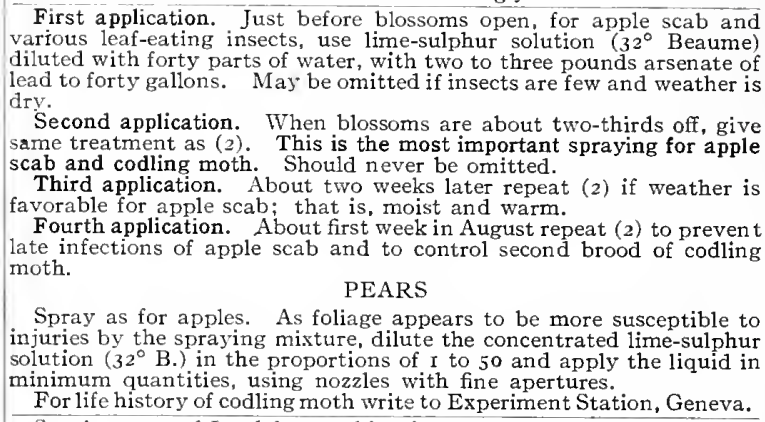 \\
\hline $\begin{array}{l}\text { Canker (N. Y. Apple) } \\
\text { Mildew, apple } \\
\text { Scab, apple and pear }\end{array}$ & $\begin{array}{l}\text { Lime Sulfur } \\
\text { Summer strength }\end{array}$ & See Arsenate of Lead for combination spray. \\
\hline Grape Rot and Anthracnose & $\begin{array}{l}\text { Lime Sulfur } \\
\text { Summer strength }\end{array}$ & $\begin{array}{l}\text { Apply when leaves are half grown; Just before blossoming; When } \\
\text { fruit has set. } \\
\text { Repeat once or twice at intcrvals of two weeks. If latter applica- } \\
\text { tions are necessary use ammonical copper carbonate solution. }\end{array}$ \\
\hline Plum Curculio & Arsenate of Lead & $\begin{array}{l}\text { PLUMS } \\
\text { First application. When "husks" or calyces drop, spray with } \\
\text { spot on European varieties use bordeaux mixture } 5-5-50 \text { with arsenate } \\
\text { of lead. } \\
\text { Second application. For leaf spot repeat spraying with bordeaux } \\
\text { mixture about ten days later. } \\
\text { Japanese varieties of plums should be sprayed as directed for peaches. } \\
\text { CHERRIES } \\
\text { Spray as for plums for San Jose scale and the curculio. } \\
\text { PEACHES } \\
\text { First application. When "husks" or calyces are dropping use two } \\
\text { pounds of arsenate of lead to fifty gallons of water for the curculio. } \\
\text { The self-boiled lime-sulphur mixture may be used as carrier of the } \\
\text { poison to control also brown rot and scab. } \\
\text { Second application. Two or three weeks later use } 88-8-50 \text { self- } \\
\text { boiled lime-sulphur mixture and two pounds of arsenate of lead. } \\
\text { Third application. About one month before fruit ripens repeat } \\
\text { treatment with self boiled mixture, omitting the poison. }\end{array}$ \\
\hline $\begin{array}{l}\text { Aphis } \\
\text { on fruit trees } \\
\text { on garden crops } \\
\text { Leaf Hopper } \\
\text { Oyster Shell Bark Louse } \\
\text { Red Spider } \\
\text { Woolly Aphis on Branches }\end{array}$ & $\begin{array}{l}\text { Kerosene Emulsion or Tobacco } \\
\text { Black Leaf }\end{array}$ & $\begin{array}{l}\text { These are contact insecticides and should be applied to exposed and } \\
\text { tender bodies of young. These are all sucking insects and food poisons } \\
\text { are of little value. } \\
\text { Be sure to penetrate covering of woolly aphis: be thorough, do not } \\
\text { allow any to escape. }\end{array}$ \\
\hline $\begin{array}{l}\text { Peach Brown Rot } \\
\text { Peach Scab }\end{array}$ & $\begin{array}{l}\text { Lime Sulfur } \\
\text { Selfboiled } 8-8-50\end{array}$ & $\begin{array}{l}\text { Spray four weeks after blossoms have fallen, again in three weeks } \\
\text { and about one month before fruit ripens. }\end{array}$ \\
\hline Raspberry Cane Blight & Resin-Bordeaux & Apply just after leaves have fallen. \\
\hline $\begin{array}{l}\text { Apple Cankers } \\
\text { Aphis Eggs } \\
\text { Pear Leaf Blister Mite } \\
\text { Red Spider Eggs } \\
\text { Tent Caterpillar Eggs } \\
\text { Woolly Aphis }\end{array}$ & $\begin{array}{l}\text { Lime Sulfur } \\
\text { Winter strength }\end{array}$ & $\begin{array}{l}\text { Spraying in spring before buds open may be substituted for this for } \\
\text { combating insects and fungus pests. However, it may be desirable to } \\
\text { apply in fall on account of rabbits. }\end{array}$ \\
\hline Grape Mildew & Flowers of Sulfur & $\begin{array}{l}\text { For mildew on grape use finely pulverized sulfur. Dust the ground } \\
\text { and vines freely during a warm, bright morning when the slightest } \\
\text { attack of mildew is suspicioned. This should not be applied while } \\
\text { the weather is damp or the vines wet. }\end{array}$ \\
\hline Tưssock Moth & Band trees & $\begin{array}{l}\text { Band trees with tanglefoot or strips of raw cotton, binding it in the } \\
\text { middle, leaving band loose above or below, Do not apply sticky } \\
\text { preparations directly on bark of trees. Use bands during June, July } \\
\text { and August. Remove egg clusters which appear in masses as a white } \\
\text { froth. }\end{array}$ \\
\hline $\begin{array}{l}\text { Crown Gall } \\
\text { Fire Blight } \\
\text { Raspberry Cane Blight } \\
\text { Strawberry Crown and Root Borers } \\
\text { Leaf Rollers }\end{array}$ & $\begin{array}{l}\text { Destroy infected parts } \\
\text { See notes }\end{array}$ & $\begin{array}{l}\text { Crown Gall is a bacterial disease of root or crown of trees. All } \\
\text { infected trees should be destroyed. Keep a constant lookout for this } \\
\text { trouble. } \\
\text { Fire Blight bacteria may extend below discolored or blackened } \\
\text { region, hence cut should be made about one foot below. Disinfect } \\
\text { knife and wound with mercuric bichloride one part to rooo parts of } \\
\text { water. } \\
\text { Strawberry plants should be dug up and burned before May I to } \\
\text { destroy insects before beetles escape to lay eggs. } \\
\text { For strawberry leaf roller burn top as soon as crop is gathered. }\end{array}$ \\
\hline
\end{tabular}




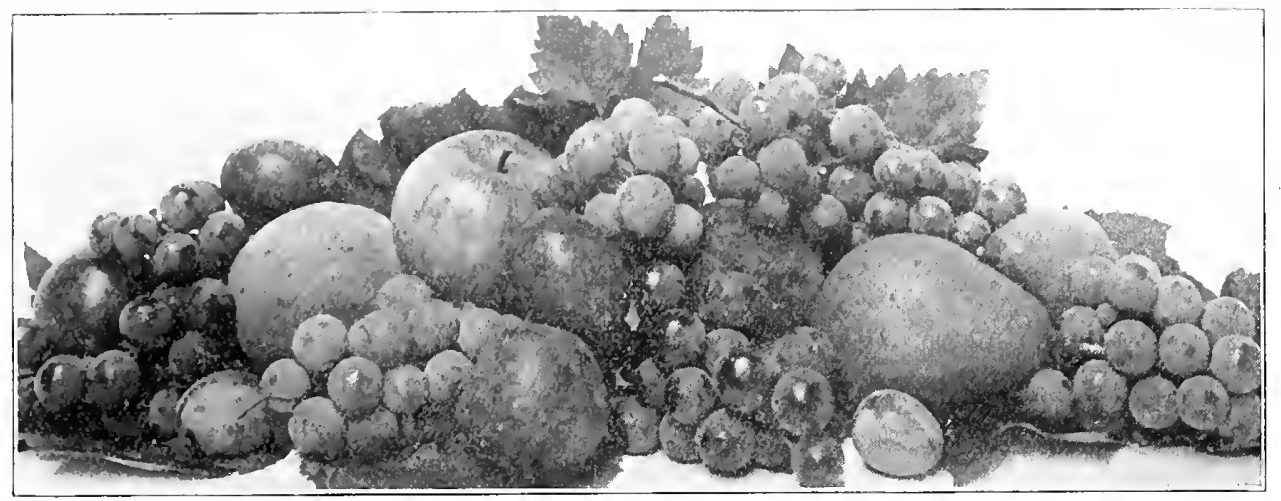

\section{Fruit Department}

\section{APPLES}

The first fruit, both in importance and general culture, is the Apple. In most sections of country, there is no farm crop which will produce one-fourth as much income per acre as will a GOOD APPLE ORCHARD.

Our collection of apples comprises ALL the best and most popular kinds in cultivation.

The standard trees are intended for orchards. These are from 5 to 7 feet in height, with proportional thickness, and from 2 to 3 years' growth from the bud.

If apple trees are planted at the rate of fifty trees to the acre, rows of peach, cherry, or plum trees can be planted between the apples, which growing more quickly than the apple trees, soon protect them from winds and thus prove a great benefit to them.

After 8 or 10 years of productiveness, as the space is needed for the Apples, the Peach Trees may be removed, leaving the orchard better for the protection, at the same time having yielded the planter a larger return for his outlay and labor.

Apple trees will thrive on nearly all well-drained soils.

\section{Select Summer Apples}

Caroline Red June. Medium, deep red, good, productive, hardy. August.

Early Harvest (Yellow Harvest). Medium, round, yellow, handsome, tender, juicy and very fine. Moderately vigorous, erect grower, productive. August.

Early Strawberry. Medium size, round, striped and covered with deep red, tender, juicy, mild, sub-acid flavor. Tree a moderate, erect grower. August.

Golden Sweet. Large, round, pale yellow, fair, sweet and fine. Tree a robust, spreading grower. Productive for orchard culture. August and September.

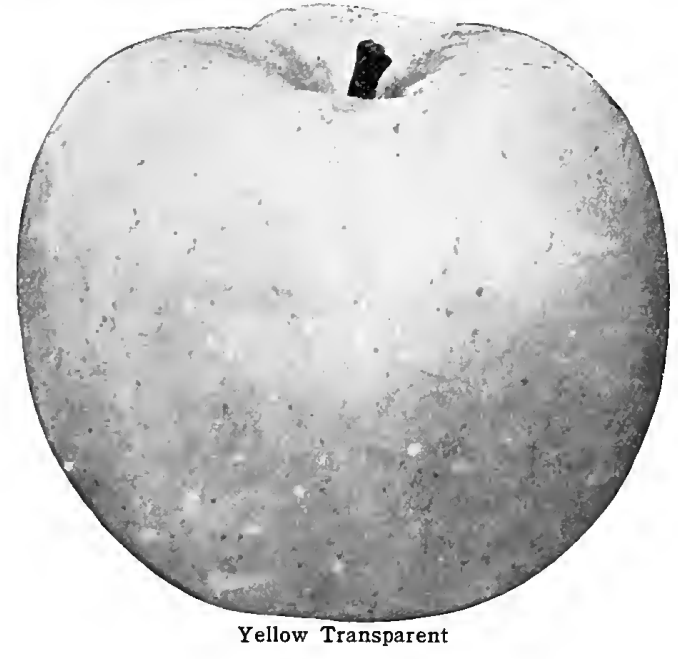

Red Astrachan. Large, round, nearly covered with deep crimson; very beautiful; flesh white, crisp, acid and good. Tree erect and productive. August.

Sweet Bough (Large Yellow Bough). Large, oblong, skin smooth, pale yellow; very tender, crisp; sweet and fine. Moderate grower, bears abundantly. August to September.

Tetofsky. A Russian apple. Very profitable for market growing; bears early. Hardy, fruit yellow, beautifully striped with red; juicy, aromatic. An annual bearer. August.

William's Favorite. Medium size, round; flesh yellowish white; flavor very mild and agreeable; bears abundantly. August and September.

9 Yellow Transparent. A very early apple. Two year old trees produce fruit. Ironclad in hardiness, and a good grower. Skin a beautiful pale yellow; fruit of good size. Ripens early in August.

\section{Select Autumn Apples}

Autumn Strawberry. Medium size, round, oval, flesh white, striped and splashed with red; tender, juicy and pleasant; bears young and abundantly. October.

Alexander. Origin Russian, a large and beautiful apple. Tree vigorous and productive. Fruit greenish yellow, faintly streaked with red on the shady side, bright red in the sun; flesh tender and juicy with a pleasant flavor. October.

Chenango Strawberry (Sherwood's Favorite). Large, roundish, bright red and yellow, very beautiful and a pleasant apple. A good and early bearer. September and October.

Duchess of Oldenburg-A beautiful Russian Apple, skin yellow, streaked with red, with a faint blue bloom; 


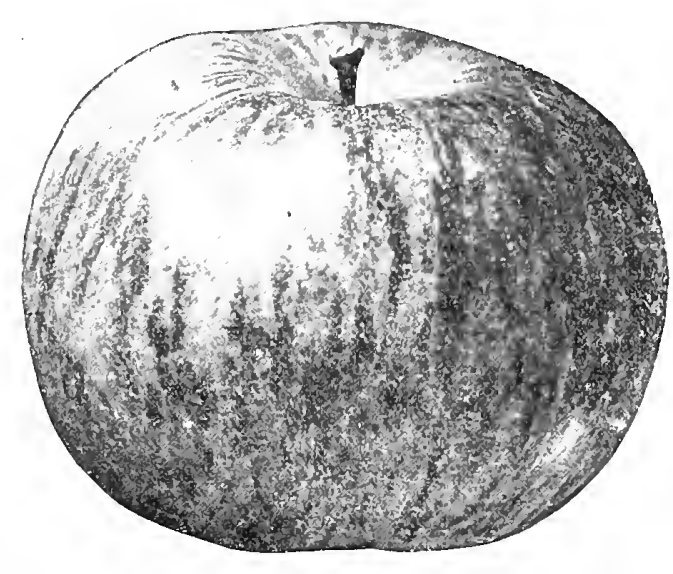

Gravenstein

flesh juicy and good. Tree a vigorous grower, and a young and abundant bearer. Succeeds well in the Northwest. September.

Fall Pippin-Very large, roundish, oblong, yellow; flesh tender and delicious. Tree a free grower and a fine bearer; one of the most valuable varieties for table or market. Grown in western New York as Holland Pippin. October to Deccmber.

Gravenstein. Large, roundish, yellow and red striped, handsome; tender, juicy, high flavored and excellent. One of the best Autumn Apples. Tree a vigorous, crect grower, and productive. September and October.

Gladstone (New). A very handsome apple resembling the Duchess of Oldenburg; the fruit is larger and of better quality and the tree a stronger grower; very hardy. Fruit large size, skin smooth, and streaked with red on a yellow ground; flesh is juicy, sprightly sub-acid, good. September.

Maiden's Blush. Medium size, flat, quite smooth and fair, pale yellow with a beautiful red cheek; tender, subacid; tree vigorous and productive. September and October.

Munson's Sweet. Medium to large: pale yellow with a red cheek; tender, juicy and good. Tree a vigorous grower and a good bearer. October and November.

Pound Sweet (Lyman's Pumpkin Sweet). Very large, round, greenish; sweet, rich and tender; excellent for baking; tree very vigorous and productive. October and November.

Porter. Medium to large, oblong, yellow, fair, handsome; juicy, sprightly, rich and excellent; one of the best; tree moderately vigorous, productive. September.

Red Beitigheimer. A valuable German variety. Fruit very large, roundish, inclining to conical; skin creamcolored ground, mostly covered with reddish purple; flesh white, firm, sub-acid, with a brisk, pleasant flavor. Ripens early fall.

St. Lawrence. Large, round, somewhat flattened; yellowish streaked with red; very handsome, juicy, pleasant and good. Tree vigorous, upright grower; fair bearer. October.

Twenty Ounce (Cayuga Streak). Very large, round, greenish yellow, striped and marked with red; rather coarse grained, good but not high flavored; one of the finest cooking apples. October to December.

\section{Select Winter Apples}

Arkansas Black - Originated in Arkansas. Tree is very hardy and thrifty. An early and uniform bearer. The fruit is large, round and smooth. Very black and dotted with whitish specks. Flesh yellow, very juicy and of a delicious flavor. It is remarkable as a keeper. New.

Bailey Sweet. Large, conical, deep red; tender, rich, honeyed sweet flavor. Tree a good upright growcr, productive. November to January.

Baldwin. Large, round, deep bright red; juicy, crisp, sub-acid, very good flavor. Tree very vigorous, upright and very productive of fair, handsome fruit; one of the bcst and most popular market apples. Deccmber to March.

Baxter. Fruit large; flesh yellowish, stained with red. Skin red with yellow ground. Russet dots. Season, November to January.

Bellefleur, Yellow. Large, yellow, with blush cheek; very tender, juicy, sub-acid. In use all winter. Very valuable. A moderate grower and good bearer.

Ben Davis (New York Pippin). Large, round, splashed with bright red on yellowish ground; tender, juicy, mild, sub-acid and pleasant flavor. Tree very hardy, vigorous grower, constant and abundant bearer. Highly esteemed in the West and Southwest. Late keeper.

Bismarck. Is making a wonderful record for hardiness and special earliness of fruiting. Two-year trees seldom fail to produce fruit; it is a valuable introduction succeeding wherever apples will grow, and entirely new in its remarkable quality of producing crops on young trees. Tree is of stocky, short growth. Fruit golden yellow splashed with red; flesh tender, pleasant, sub-acid. Will keep into March

Boiken. When fully ripe resembles Maiden's Blush in color; rosy red and bright yellow; tree vigorous and very productive; foliage healthy. Keeps well into spring.

English Russet. Medium size, ovate or conical, yellow russet; crisp, sub-acid. A strong upright grower, and a regular and great bearer. Keeps till June.

Fallawater (Tulpahocken). Large, globular, yellowish green, dull red cheeks, juicy, crisp, pleasant, peculiar subacid flavor. Tree a strong grower, very productive. November to March.

Fameuse (Snow Apple). Medium size, round, very handsome, deep crimson; flesh snowy white, tender, juicy, 


\begin{tabular}{|l|l|l|}
\hline W. \& T. SMITH COMPANY, GENEVA, N. Y. & T. \\
\hline
\end{tabular}

high flavored and delicious. Tree vigorous, productive and very hardy. November to February.

Gano. Originated in Missouri. Similar but superior to Ben Davis. It has all the good qualities in a higher degree, more brilliant coloring, runs more even in size and keeps fully as late. The tree is vigorous and hardy; is a rapid grower; bears while young, color bright red without stripes or blotches and large and even in size. February to March.

Gideon. Tree hardy, vigorous, and an early, prolific bearer. Fruit medium to large; color golden-yellow with a handsome blush on the sunny side; flesh fine, juicy, subacid; in form and general appearance resembles somewhat the Yellow Bellflower. November to January.

Golden Russet. Medium size, dull russet, with a tinge of red on sunny side; flesh greenish, crisp, juicy. Tree a good grower, with light colored speckled shoots, by which it is easily known; bears well. November to April.

Grimes' Golden. Medium to large, cylindrical, flesh yellow and firm, very fine grained with a rich, refreshing flavor; of the best quality, and one of the most valuable. Tree vigorous, productive and bears early. January to April.

Hendrick Sweet (Sweet Winesap). Fruit medium, round oblate; color red, splashed with deep crimson; flesh tender, juicy, very sweet and rich. None better as a market variety. November to May.

Hubbardston Nonesuch. Large, round, beautiful, yellow and red; tender, juicy, aromatic, rich and delicious. Tree a strong grower and productive. November to January.

Jonathan. Medium size, pale yellow, striped with red; flesh white, tender and juicy, of the Spitzenburg class; the tree is an abundant bearer. November to March.

King of Tompkins County. Very large, round, oblate, yellow striped and clouded; an abundant annual bearer. December to April.

Lady's Sweet. Large, round, green and red striped, with a thin white bloom; very rich, sweet, and agreeably perfumed; one of the best sweet winter apples. Shoots rather slender but erect; very productive. December to April.

Lawver. Tree vigorous, spreading; an early annual bearer. A beautiful fruit and a long keeper. Color dark red covered with small dots; flesh white, firm, crisp, sprightly, aromatic, mild, sub-acid. January to May.

Longfield. A new Russian variety and one of the best. Tree a strong grower and an early, abundant and annual bearer. Flesh white, fine, tender and juicy, with a rich, sprightly, sub-acid flavor. Season December to April. Valuable for cold climates.

Magog Red Streak. Tree very hardy and vigorous; bears every year. Fruit medium, round, inclining to oblong; skin yellow and faintly splashed with light red;
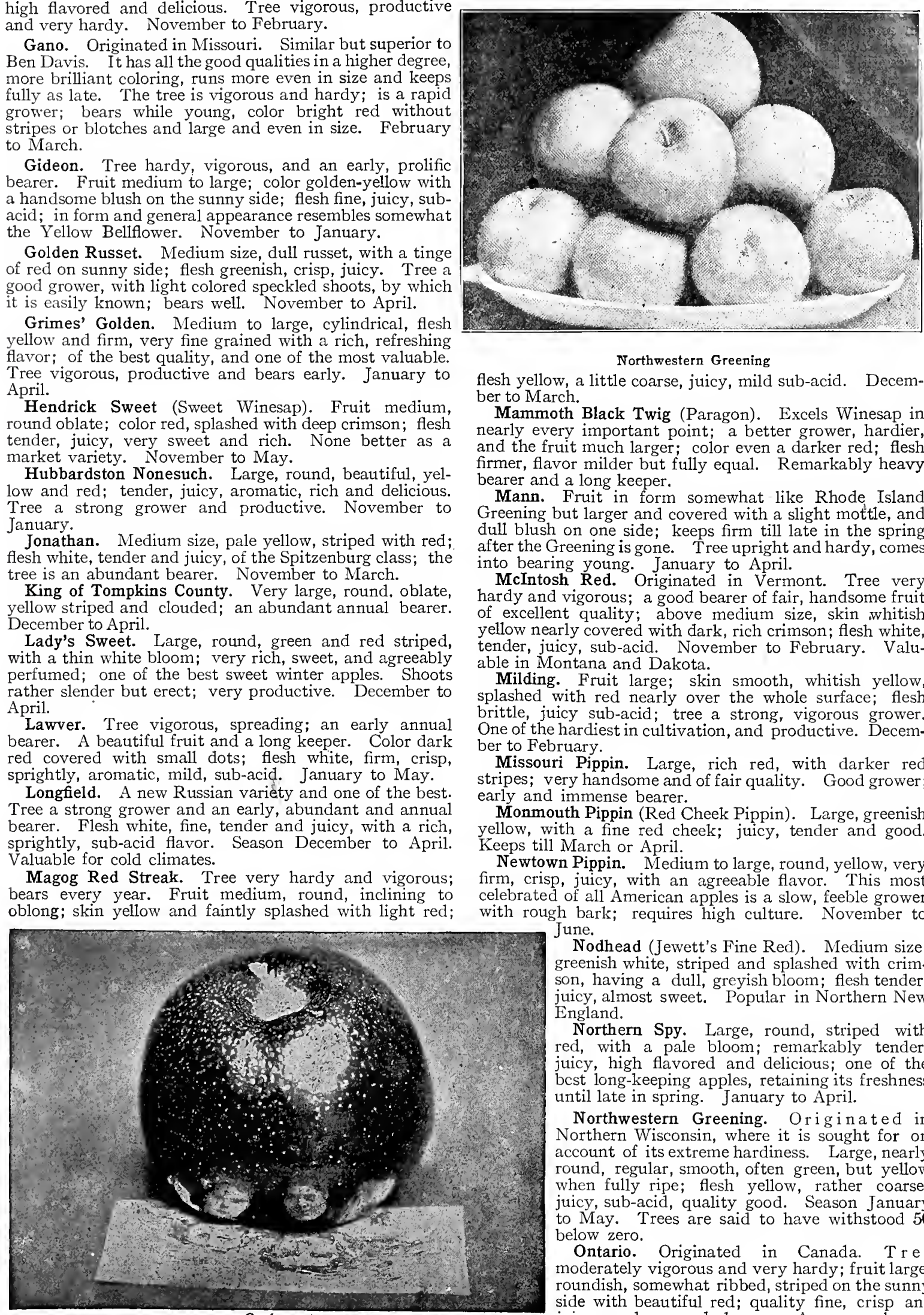

\section{Northwestern Greening}

flesh yellow, a little coarse, juicy, mild sub-acid. December to March.

Mammoth Black Twig (Paragon). Excels Winesap in nearly every important point; a better grower, hardier, and the fruit much larger; color even a darker red; flesh firmer, flavor milder but fully equal. Remarkably heavy bearer and a long keeper.

Mann. Fruit in form somewhat like Rhode Island Greening but larger and covered with a slight mottle, and dull blush on one side; keeps firm till late in the spring after the Greening is gone. Tree upright and hardy, comes into bearing young. January to April.

McIntosh Red. Originated in Vermont. Tree very hardy and vigorous; a good bearer of fair, handsome fruit of excellent quality; above medium size, skin whitish yellow nearly covered with dark, rich crimson; flesh white, tender, juicy, sub-acid. November to February. Valuable in Montana and Dakota.

Milding. Fruit large; skin smooth, whitish yellow, splashed with red nearly over the whole surface; flesh brittle, juicy sub-acid; tree a strong, vigorous grower. One of the hardiest in cultivation, and productive. December to February.

Missouri Pippin. Large, rich red, with darker red stripes; very handsome and of fair quality. Good grower; early and immense bearer.

Monmouth Pippin (Red Cheek Pippin). Large, greenish yellow, with a fine red cheek; juicy, tender and good. Keeps till March or April.

Newtown Pippin. Medium to large, round, yellow, very firm, crisp, juicy, with an agreeable flavor. This most celebrated of all American apples is a slow, feeble grower with rough bark; requires high culture. November to June.
Nodhead (Jewett's Fine Red). Medium size; greenish white, striped and splashed with crimson, having a dull, greyish bloom; flesh tender, juicy, almost sweet. Popular in Northern New England.

Northern Spy. Large, round, striped with red, with a pale bloom; remarkably tender, juicy, high flavored and delicious; one of the bcst long-keeping apples, retaining its freshness until late in spring. January to April.

Northwestern Greening. Originated in Northern Wisconsin, where it is sought for on account of its extreme hardiness. Large, nearly round, regular, smooth, often green, but yellow when fully ripe; flesh yellow, rather coarse; juicy, sub-acid, quality good. Season January to May. Trees are said to have withstood 50 below zero.

Ontario. Originated in Canada. Tree moderately vigorous and very hardy; fruit large, roundish, somewhat ribbed, striped on the sunny side with beautiful red; quality fine, crisp and juicy, and a good keeper. An annual and A photograph reflected on its polished surface 
Opalescent. The handsomest apple on the market. An annual bearer of beautiful high quality fruit. Size large; color light, shading to very dark crimson and susceptible to a very high polish; hence, its name. December to March.

Peck's Pleasant. Large, round, smooth, pale yellow, with a bright blush; juicy, crisp, rich, and high flavored. Tree erect, vigorous and productive. December to March.

Peter. Originated in Minnesota from seed of the Wealthy, which it resembles in size and color. In quality it is BETTER, season four to six weeks later. Has endured 45 degrees below zero, without injury, and borne fine crops, where other hardy varieties failed. A strong upright grower, and promises to be the apple for the great Northwest.

Rome Beauty. Large, round, yellow and light red; handsome, juicy, crisp, sub-acid; tree a moderate grower, good bearer; popular in the Southwest. December to February.

Roxbury Russet. Medium to large; yellow russet; crisp, good, sub-acid flavor. Tree vigorous and productive. Very popular on account of its long keeping. June. Scott's Winter. Originated in Vermont. Tree hardy, an early and abundant bearer. Fruit medium, round, light red in blotches and streaks; flesh yellowish white, reddened near the skin, rather acid and good in quality; late keeper. January to May.

Seek-No-Further (Westfield). Medium to large, round, striped with dull, red russet dots; fine grained, tender, rich and excellent. Tree a good grower, and a fair bearer, fruit fair and fine. November to February.

Smith's Cider. Medium to large, oval, yellow and light red; tender, juicy, crisp and acid. Tree vigorous and very productive. Valuable in the South and West. December to March.

Smokehouse. Origin, Lancaster Co., Pa. Fruit medium size; yellow, splashed with crimson, and sprinkled with large, gray and brown dots. Flesh yellowish, firm, juicy, [sub-acid. V al ued for cooking. December to February.

Spitzenburg (Esopus). Large, Iround, brilliant red, with gray dots; firm, rich, crisp, juicy, spicy and delicious. Tree rather a slow grower, but with high culture forms a large and spreading tree; a good bearer and a popular fruit. December to April.

Stark (Pride of Maine) An early and abundant bearer. Fruit large and valued for its long keeping; skin greenish yellow, shaded and striped with red, and thinly covered with light brown dots; flesh yellow, moderately juicy, mild. January to May.

Alexander

Pewaukee. A seedling from Duchess of Oldenburg. Fruit medium to large, round; skin bright yellow, striped and splashed with dark red, and overspread with white dots; flesh white, tender, juicy, sub-acid; very hardy. January to May.

Rambo. Medium, flat, streaked red and yellow; very tender, juicy, and fine flavored. Tree an upright grower, hardy and productive. October to December.

Red Canada (Steele's Red). Medium, oblate, red; tender, crisp, rich, delicious. Tree thrifty but a slender grower; productive. January to May.

* Rhode Island Greening. Large, round, green or greenish yellow; tender, rich, high flavored and excellent; one of the most widely disseminated and popular apples. Tree vigorous and spreading, a great and constant bearer. The leader among market apples in New York State. November to March.

Ribston Pippin. The best English apple. Fruit medium, round, greenish yellow, mixed with a little russet near the stalk end, clouded with dull red on the sunny side; flesh deep yellow, firm with rich aromatic flavor. November to April.

Rolfe. Originated in Maine. Fruit large of magnificent appearance; color dark red. An abundant and annual bearer. Quality prime, both for eating and cooking. November to January.
Stayman's Winesap. It is now attracting attention everywhere as a profitable market variety. It has large size, bright red color, great productiveness and best quality to commend it. The tree is a vigorous grower and like its parents, is irregular and drooping in habit, and adapts itself readily to different soils and situations. Season November to April.

Sutton Beauty. Fruit medium to large, round, handsome, skin waxen yellow, striped with crimson; flesh white, tender, juicy, sub-acid; quality very good; keeps well. Tree a free grower and productive. A good market apple. November to April.

Talman Sweet. Medium size, nearly round, whitish yellow; firm, rich, very sweet, excellent for baking, a valuable and popular variety. Tree vigorous, upright and very productive. November to April.

Wagener. Medium, flattened, light yellow, nearly covered with bright red; handsome, firm, crisp; juicy, sub-acid, excellent flavor. Tree a fair grower, an early and abundant bearer. December to March.

Walker's Beauty (New). Originated in Allegheny County, Pa. Tree a strong, upright grower; one of the best in the nursery. Fruit very large; color crimson on yellow ground; flesh firm, sub-acid. Season January to June. 


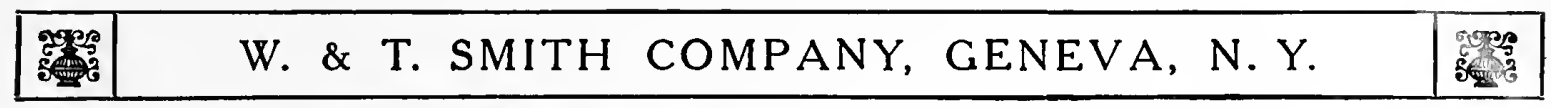

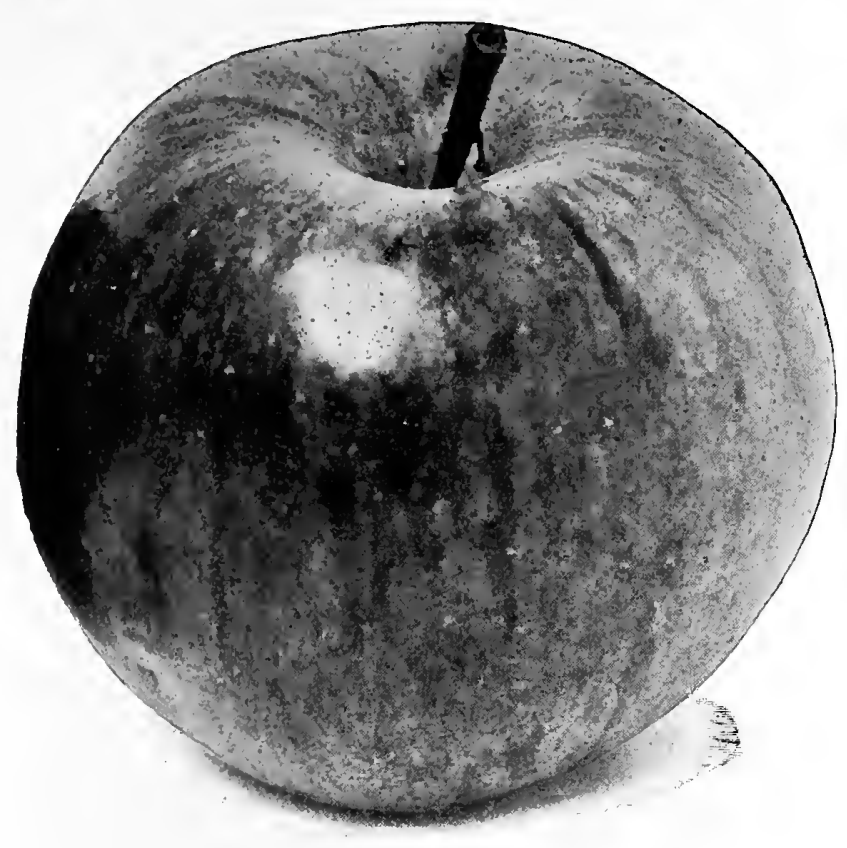

Fameuse.

Winter Banana. Fruit large; clear, pale yellow, with pinkish blush; attractive in appearance; of good desert quality. November to April.

Wolf River. Very large; beautiful red in the sun, on a yellow ground; strong grower and a good bearer. Original tree in Wisconsin is 40 years old, very healthy and extremely hardy. December to March.

Walbridge. Medium size, oblate, regular; skin pale yellow shaded with red; flesh crisp, tender, juicy. Esteemed especially in cool climates for its hardiness and productiveness; a late keeper; tree very vigorous. January to May.

Wealthy. Originated near St. Paul, Minn. Fruit medium round; smooth, mostly covered with dark red; flesh white, fine, juicy, sub-acid, very good. Tree a free grower and very productive; valuable on account of its hardiness and good quality; December to February.

Winesap. Large, round, deep red; medium quality; keeps well. Tree a moderate grower and good bearer; succeeds well in the West, and is valuable and popular. December to May.

York Imperial. Origin, York Co., Pa. Fruit medium size; white shaded with crimson in the sun; firm, crisp, juicy, pleasant, mild, sub-acid. Tree moderately vigorous and productive; a popular Pennsylvania variety. November to February.

Other Apples grown and recommended by us:

Benoni (Summer).

Bottle Greening (Winter).

Fall Jennetting.

Fall Orange (Summer).

Gilliflower (Winter).

Hurlbut (Winter).

Haas (Fall).

Jersey Sweet (Fall).

Keswick Codlin (Summer).

North Star.

Minkler (Winter).

Palmer Greening (Winter).

Peerless.

Rawle's Janet (Winter).

Sops of Wine (Summer).

Belle de Boskoop (Winter).

Lady (Winter).

Salome (Winter).

Walter Pease (Winter).

\section{CRAB APPLES}

\section{For Ornament or Preserving}

There are several points to which we wish to direct attention and upon which we base our recommendation of these hardy fruits.

1. They can be planted in any kind of soil, and in the most exposed situations; are not injured by the coldest weather.

2. They come into bearing very early, usually the second year from planting, and bear EvERy year.

3. They are unequalled for cider, or vinegar and for jelly.

4. They can be dried, cooked, canned, or preserved with the skin on, thus saving a great deal of trouble.

5. The size of the fruit varies from one and one-half to two and one-half inches in diameter, being large enough to quarter and core for drying.

Gen. Grant. Of large size for a crab. Round, oblate, cream yellow ground, broken stripes becoming dark red on the sun exposed side; slender stem; flesh white, very mild, sub-acid. October.

Excelsior. Raised from seed of the Wealthy, which is known as one of the handsomest, hardiest and best flavored of our new fruits. Ripens in early fall, about the size of Fameuse. Being an early crab apple, it fills a most important place.

Hyslop. Large size, dark crimson, with bloom; very showy and most beautiful of all the class. Tree very hardy. Popular and desirable. Late.

Martha. A new crab raised from the seed of the Duchess of Oldenburg. "A rapid stiff grower;" a great bearer of beautiful fruit; glossy yellow shaded with light, bright red. Fruit mild and tart. Season October and November.

Transcendent. Of the largest size of this class of apples, red, showy, excellent and very handsome; one of the most desirable. September to October.

Van Wyck Sweet. Large, yellow, shaded with light red, sweet and tender. October to November.

Whitney. Large, averaging one and one-half to two inches in diameter; smooth, glossy green splashed with carmine; flesh firm, juicy and rich; a great bearer and very hardy. Tree a fine grower, with dark green, glossy foliage. 


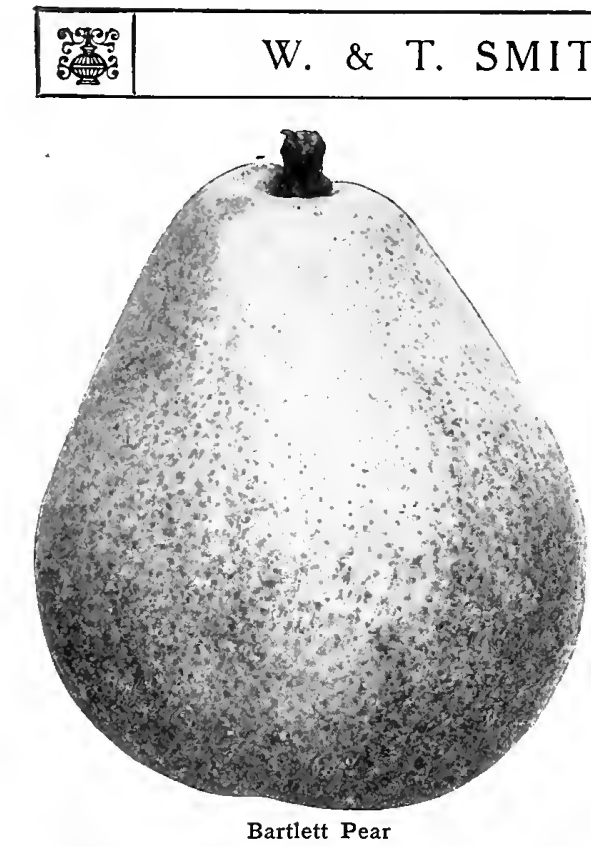

COMPANY, GENEVA, N. Y.

PEARS

OUR SoIL is especially well adapted for producing the finest and hardiest pear trees, those containing the most life, body and strength, and it has been for many years an admitted fact that our pear trees cannot be excelled.

Standard Trees on pear stock are preferable for the orchard. These are best from four to six feet high.

DWARFS are budded on the Angers Quince (marked $Q$ on the list), and are best for the garden; they should be two or three years old, and from three to five feet high, having been well cut back in the nursery rows when one year old, to produce long side branches. They should be planted in rich, well tilled soil, and kept under good cultivation. The general rule is to remove every spring, after hard freezing is over, and before the sap. starts, one-half or two-thirds of the previous summer's growth.

These dwarf trees must always be planted sufficiently deep to cover the junction of the pear and quince, 2 to 3 inches.

Gathering Pears-Most varieties of pears are greatly inferior in flavor when allowed to ripen on the tree. Gather when, on gently lifting the fruit, the stem will readily separatefrom the limb; this will be from one to two weeks before they are ripe. Ripen in the house, placing the fruit in a dark room until fully matured. Winter pears should hang on the tree until there is danger of frost-say from first to tenth of October.

THIN THE FRUIT-We cannot urge too strongly the following suggestion: When pear trees are heavily laden the fruit should be thinned when about one-third grown, else the fruit will be poor and the trees injured.

The pear succeeds in most soils, but does best on a rather heavy clay or loam.

\section{Select Summer Pears}

Bartlett. Large, yellow, pyriform; melting buttery, rich and musky flavor; tree bears young; a good erect grower, very productive; one of the most popular pears. September. Q.

Clapp's Favorite. A large, fine pear resembling the Bartlett, but without its musky flavor; pale lemon yellow, with brown dots; fine texture, melting buttery, juicy, with a rich, sweet, delicate, vinous flavor. Tree hardy and very productive. August and September. Q.

Koonce. Medium to large, pyriform, very handsome; yellow, one side covered with bright carmine, sprinkled with brown dots; flesh juicy. Sweet, spicy, good. Ripens with the earliest. Tree a remarkably strong grower, hardy and very productive. August.

Manning's Elizabeth. Small to medium, bears in clusters; orimson and gold color, very beautiful; melting, rich, sugary, sprightly perfumed flavor, excellent. Tree a moderate grower and very productive. One of the very best early pears. August. $Q$.

Wilder. One of the earliest. Fruit small to medium, beil-shaped, smooth, pale yellow ground with deep shading of brownish carmine; flesh whitish; yellow, fine grained, tender; flavor sub-acid, sprightly; quality very good, productive; probably the best early market sort. First of August. $Q$.

\section{Select Autumn Pears}

Beurre Clairgeau. Large, skin yellow, inclined to fawn, shaded with orange and crimson, covered with russet dots; flesh yellow, juicy, somewhat granular, with a sugary, perfumed, vinous flavor. The size, early bearing, productiveness and exceeding beauty, renders this a valuable sort. Best as standard.

Flemish Beauty. Large, pale yellow, brownish cheek; melting and delicious. Tree vigorous. Bears young and abundantly. One of the most hardy. September to October. Q.

Garber. One of the Japan Hybrids; earlier and larger than Kieffer; hardy, productive, early bearer. September and October.

Howell. Large, light yellow, with a fine red cheek; rich, sweet, aromatic flavor. Tree an upright, free grower. An early and profuse bearer. Very hardy and valuable for the west. September and October. $Q$.

Idaho. A native of Idaho. Fruit is bright golden yellow, with red cheek, covered with spots. The shape is more that of an oblong apple than a pear. Flesh melting, juicy, with a sprightly vinous, delicious flavor. Quality good. $Q$.

Kieffer's Hybrid. Large, rich golden, slightly coarse, juicy, with a pronounced quince flavor. Its freedom from blight, early bearing, wonderful productiveness, exceedingly vigorous growth, and handsome appearance all indicate that it has come to stay. Properly picked and CARED FOR it is a good pear to eat out of hand and for canning purposes has no superior. October to November.

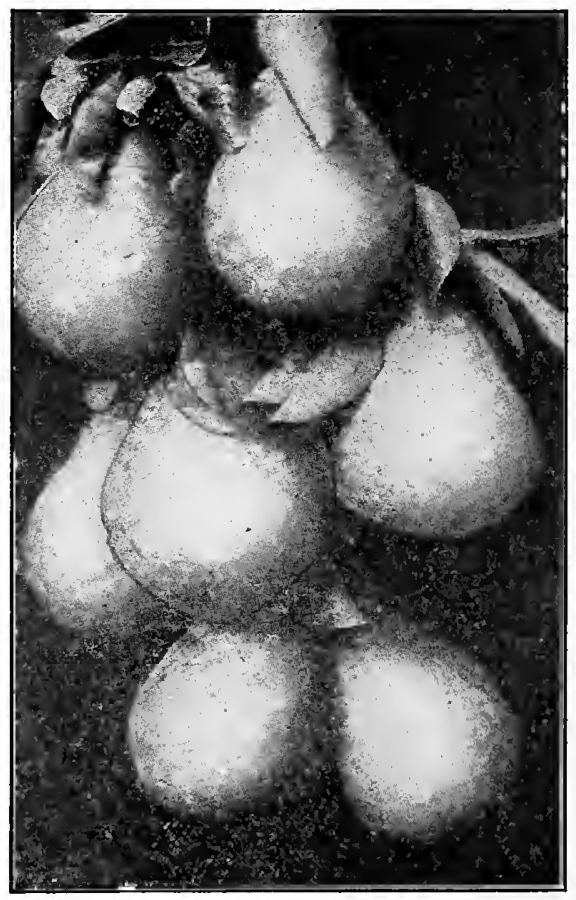


Louise Bonne de Jersey. Large, smooth, greenish yellow with a red cheek; melting and rich. Tree upright, productive; desirable on the quince. October. $\mathrm{Q}$.

Sheldon. Large, round, russet with a red cheek; melting, juicy, rich, sugary, perfumed and delicious. One of the finest pears. Tree handsome, hardy, vigorous and productive. October and November. (Not grown on quince.)

Seckel. Medium to small, yellowish brown, with a red cheek, melting, sweet, spicy, very rich and delicious. The standard of excellence. Tree a slow but stout, erect grower, hardy and productive. October. $Q$.

Vermont Beauty. A beautiful new seedling pear; fruit of medium size, round, skin yellow, nearly covered with carmine; flesh melting, sprightly, very good. Tree hardy, healthy and very productive. October.

Worden Seckel. A seedling of Seckel. Fruit medium size, borne in clusters; juicy, buttery, fine-grained, with a flavor and aroma fully equal to that of its parent, which it surpasses in size, beauty and keeping qualities. Ripens in October, but will keep in good condition till December.

\section{Select Winter Pears}

Beurre Bosc. Large, long, cinnamon russet, handsome; half-melting, juicy, rich, slightly perfumed and delicious.
Tree moderately vigorous, a good and regular bearer; fruit perfect and of the highest flavor. Very desirable and valuable. October.

Beurre d'Anjou. Large, obovate, pyriform, greenish russet, sometimes shaded with crimson; melting; juicy, vinous, perfumed, rich and delicious. Tree very vigorous, hardy and productive. Succeeds well on the quince. The best for late fall and early winter, both for home use or market. Commences to ripen in October, keeping with care until February. Its quality is the best. $Q$.

Duchesse d'Angouleme. Very large, greenish yellow, russet spots, juicy, rich, sweet and fine. Tree vigorous and bears well. It attains its highest perfection on the Quince. October and November, $Q$.

Lawrence. Medium size; fine golden yellow; melting, sugary and aromatic. An American pear of great excellence. Tree a moderate grower, handsome, hardy, and good bearer. The most valuable of the early winter pears. December. Q

Lincoln Coreless. Practically coreless. It will keep for several months. Fruit large, quality very good, rich and juicy. When ripe, the skin is of a rich golden tint, and the flesh is yellow. Tree a strong grower, hardy as Bartlett.

Winter Nellis. Early winter, medium size, dull russet, good flavor, heavy crops.

\section{DWARF PEARS}

The following varieties are particularly recommended for cultivation on the quince. All are vigorous and handsome growers, hardy and productive. Bartlett, Beurre d'Anjou, Clapp's Favorite, Duchess d'Angouleme, Howell, Louise Bonne de Jersey, Lawrence Manning's Elizabeth, Seckel, Wilder's Early, Worden Seckel, Flemish Beauty.

\section{CHERRIES}

Being the earliest fruit in market, the cherry holds a strong place in public favor and for this reason commands a good price in all markets.

Farmers are planting cherry trees extensively on the road sides and on lawns for shade and fruit, thus combining usefulness and profit, and for these two purposes the stronger growing varieties are to be preferred, especially the black sorts.

The cherry tree universally requires a dry soil, and is naturally a hardy tree, succeeding in the lightest soil, or dryest situations. Cherries are divided into two classes. Hearts and Bigarreau, varieties of rapid growth, with large glossy leaves, forming fine pyramid shaped heads, and producing large crops of luscious sweet fruit. Dukes and Morellos, which are all of slender growth and do not attain so large a size, generally produce acid fruit, are also hardier and better adapted for raising fruit for market. Many trees produce from five to six bushels per tree.

\section{Heart and Bigarreau Cherries}

Black Heart. Hardy, strong, large grower. Fruit above medium size; skin glossy dark purple, becoming deep black, when fully ripe. Ripens last of June.

Black Eagle. Large, black; tender, rich and high flavored. Tree a rapid, stout grower, forms a dense head; moderate bearer. Beginning of July.

Black Tartarian. Very large, bright purple, glossy black; half tender, juicy, rich and fine. Tree a rapid, vigorous, upright grower and great bearer. One of the popular kinds. Ripens last of June and beginning of July.

Coe's Transparent. Vigorous growth. Medium; pale amber and red; one of the best. Ripening end of June.

Downer's Late. Rather large, light red; very tender, juicy, rich, sweet and delicious; hangs long on the tree, and not liable to rot in wet weather. Tree hardy, vigorous; a regular and great bearer. Middle of July.

Dikeman. This gem among Cherries has the advantage of being the latest ripening Sweet Cherry known; hence, placed on the market two or three weeks after other sorts are gone, it commands highest price. Black, good size, and in texture reminds one of the Cherries from the Pacific slope, being meaty and solid. It is this quality alone which makes it such a good shipper and keeps it so long.

Early Purple Guigne. Medium, purple; tender, juicy, rich and sweet. Tree hardy, slender and of spreading growth, and a good bearer. The earliest fine variety. First to middle of July.

Elkhorn. Large; flesh purple, juicy, tender, fine flavor; productive. Middle of July.

Governor Wood. Large; light yellow and bright red; nearly tender, juicy, sweet, rich and delicious. Tree very vigorous and productive; one of the most popular. Middle to end of June.

Ida. An abundant bearer of luscious yellow and red fruit. Ripens in June. We consider this the best light colored cherry grown.

Lambert. Very large, dark purplish red turning almost jet black when ripe. Flesh firm, rich and juicy; an enormous bearer.

Mercer (New). Fruit large, dark red, fine flavored, sweet. A good shipper; tree very hardy; an annual bearer and not liable to be wormy or rot. It gives great promise of being one of the very best for orchard or family purposes. Early.

Napoleon Bigarreau. Very large, pale yellow and red; very firm, juicy, sweet, and good. Tree spreading, vigorous, and exceedingly productive. Early in July.

Rockport Bigarreau. Large, amber and light red; half tender, sweet, rich and excellent. Tree vigorous, erect, beautiful and productive. Last of June and first of July. A very valuable variety. Should be in every collection. 
Schmidt's Bigarreau (New). Remarkably hardy and productive. Fruit of the largest size; a deep mahogany color; flesh dark, tender, juicy with a fine, rich flavor. Stone small. July.

Windsor. Fruit large; liver colored. Flesh remarkably firm, sweet and of fine quality. Tree hardy and very prolific. Middle of July.

White Caroon. Fruit large and fine, flavor rich subacid, choice for canning. Middle of July.

Yellow Spanish. Large, pale yellow, with a red cheek; flesh firm; juicy and delicious; handsome. Tree vigorous and productive. First of July.

\section{Duke and Morello Cherries}

Baldwin. Fruit large, almost round; very dark, transparent wine color; Havor slightly acid ye the sweetest and richest of the Morello type. Unexcelled in earliness, vigor, hardiness, quality and productiveness.

Bing. A native of Oregon, fr uit very large, bright and glossy. Color very dark crimson; one of the largest cherries ever produced, and of the most excellent quality. Season July.

Lutovka. Season middle to last of July. Fruit large. Color rich, dark red. Flesh red, tender, juicy, with a mild sub-acid flavor. Extra hardy; a vigorous grower and very productive.

Dyehouse. Partakes of both the Duke and Morello in wood and fruit; a very early and sure bearer; ripens a week before the early Richmond, of better quality and quite as productive. June.

Early Richmond. Medium size, dark red; juicy, rich acid flavor. The stone adheres to the stem. One of the most valuable of the sour cherries. Tree a slender grower, with a round spreading head, and exceedingly productive. The most hardy of all. Ripens through June.

Empress Eugenie. A new French cherry, rather dwarf in habit; very productive. Fruit large, roundish flattened, skin rich, dark red; flesh red, tender, rich, juicy, sub-acid, very good; stone small. Middle of June.

Louis Phillippe. Fruit largest of its class, round and regular; color rich, dark red when fully ripe; flesh tender, juicy, sprightly, mild acid. Fruit remains perfect on the tree two weeks without injury. Middle to last of July.

Late Duke. Large, light to dark red; tender, juicy, sprightly sub-acid. Tree vigorous, hardy, productive. Ripens gradually, and hangs on the tree from middle of July into August.

May Duke. Large, dark red, tender, melting, juicy, and when fully ripe, rich and excellent flavor. Ripens a long time in succession. Tree hardy, vigorous and upright in growth. Middle of June.

Montmorency (Large Montmorency). A cherry of the Richmond class but larger and more solid. A more upright grower, equally hardy and a heavy cropper. Ripens from seven to ten days later than the Richmond, entirely escaping danger from spring frost. A valuable addition to our orchard fruit.

Morello English. Large, dark red, nearly black; tender, juicy, sub-acid. Valuable for preserves. Tree small, slender growth, productive. July and August.

Olivet. A large, globular, very shining, deep red sort. The flesh is red; with a rose-colored juice, tender, rich and vinous, with a very sweet sub-acidulous flavor. It ripens in the beginning of June and continues till July without losing its quality.

Ostheim. A very hardy cherry, imported from St. Petersburg, Russia. Color dark red; flesh very dark, juicy, with a sub-acid flavor. Its hardiness and productiveness renders it valuable. Middle of July.

Reine Hortense. Very large, bright red; tender, juicy, nearly sweet. Tree a healthy, handsome grower, and productive. Very desirable. Middle to last of July.

Wragg. Very hardy. Fruit dark, juicy and rich. Tree a dwarf but vigorous grower and very prolific. Nearly like English Morello.

\section{Rocky Mountain Cherry}

Improved Dwarf. From Colorado. It has withstood a temperature of $40^{\circ}$ below zero. Exceedingly productive. Fruit jet black when ripe, and in size averaging somewhat larger than the Eng. Morello. Its season of ripening being after all others are gone. In flavor it is akin to the sweet Cherries. Worthy of cultivation for an ornamental shrub. 
Plums, like pears, attain the highest perfection on our beavy soils.

We have divided our list of plums into three general classes, European, Japan and Native.

The European plums are mostly of English or French origin and are distinguished for their high quality. They require good cultivation and the most intelligent care of any fruit, but they richly repay the diligent orchardist.

Japan plums are attracting the attention of growers because of their showy appearance, their fungus resisting foliage and adaptability to almost any soil PLUMS and climate.

Native plums are hardy, produce large crops mostly of early and medium sized highly colored fruit. They seem to thrive in the most unfavorable locations of soil and climate. When planting this type, several varieties should be planted in the same orchard so the blossoms will fertilize properly.

\section{Plums of European Type}

Arch Duke (New). A large, dark and very prolific plum ripening October 1st. A very valuable addition to late plums and profitable to the amateur and orchardist. Last of September.

Bradshaw. A very large, oval, dark violet red; juicy, sweet and good; a valuable market variety. Tree very vigorous; erect and productive. Middle of August.

Coe's Golden Drop. Very large, light yellow; rather firm, rich, sweet and good; adheres to the stone. Tree moderately vigorous and productive. A valuable late variety. Last of September.

Empire. This new variety has been thoroughly tested for a number of years, and is pronounced by plum growers to be the most valuable market sort. Fruit is very large and oval. Color reddish purple, covered with bloom. Tree ironclad in hardiness, strong grower, enormous bearer. Ripens September 5th to 10th.

Fellemberg (Italian Prune). A fine late plum; oval, purple; flesh juicy and delicious; parts from the stone; fine for drying. Tree very productive. September.

French Damson. Tree a better grower than the Shropshire or Blue Damson; hardy, an annual bearer; very productive. Fruit medium; dark copper color, with a rich bloom, and the best of the Damsons for market; ripens two weeks later than Shropshire. October.

Geuii. Fruit very large, bluish purple, covered with thick bloom; flesh yellowish green, coarse, sweet and pleasant; great bearer and very early; tree a hardy and rapid grower. One of the most profitable for market. First to middle of September.

German Prune. A large, long oval variety, much esteemed for drying; color dark purple; of very agreeable flavor. September.

Giant Prune (New). For a market, table and shipping Prune the Giant stands pre-eminent, owing to its great size, beauty of form and color, its firm, rich, sweet delicious flesh, which separates readily from the stone. It has a yellow flesh of remarkable sweetness, and very firm. The tree is a strong, handsome grower, and the fruit is produced in the utmost profusion and of uniform size. September.

Grand Duke. Fruit oval with a short neck. Skin almost black, but reddish when shaded and covered with bloom; flesh yellow, adhering closely to the stone; with a sweet, rich flavor when fully ripe. Leading plum growers state that it is one of the most profitable plums for market. September.

Green Gage. Small; considered the standard of excel. lence; slow grower. Middle of August.

Imperial Gage. Large, oval, greenish; juicy, melting, sweet, rich, sprightly and agreeable; parts from the stone. Tree very vigorous and productive. One of the best plums, valuable for market. Middle of August and first of September.

Lombard. Medium, oval, violet red; juicy, pleasant and good; adheres to the stone. Tree vigorous and very productive. A valuable market variety; one of the most hardy and popular. Middle to last of August.

Monarch (New). Fruit dark purple covered with a thin bloom; large size, specimens measuring six inches in circumference; flesh pale greenish yellow, parting freely from the stone; juicy with a pleasant flavor. It is a leading market sort. The tree is a vigorous grower. September.

Moore's Arctic. A hardy plum. Tree healthy, vigorous, an early and abundant bearer. Fruit medium; skin purplish black, thin blue bloom; flesh greenish yellow, a little coarse, juicy sweet. Ripens early in September.

Niagara. Very large; reddish purple, entirely covered with gray bloom; flesh deep greenish yellow. Said to be identical with Bradshaw. Vigorous. Middle of August.

Pond's Seedling. Very large, oval, reddish violet; a little coarse, very juicy, sugary and handsome. Tree a good grower and productive. August.

Reine Claude (Bavay's Green Gage). Round, greenish yellow, juicy, melting, sugary, rich and excellent; separates from the stone. Tree very vigorous and remarkably productive. A valuable market plum. Ripens last of September.

Smith's Prune (Diamond). Fruit very large, oval, black. Ripens in September. A most valuable market variety. Tree a fine grower, hardy and productive.

Shropshire Damson. Originated in England. Dark purple, larger than the common Damson, very productive; ripens about September first. 


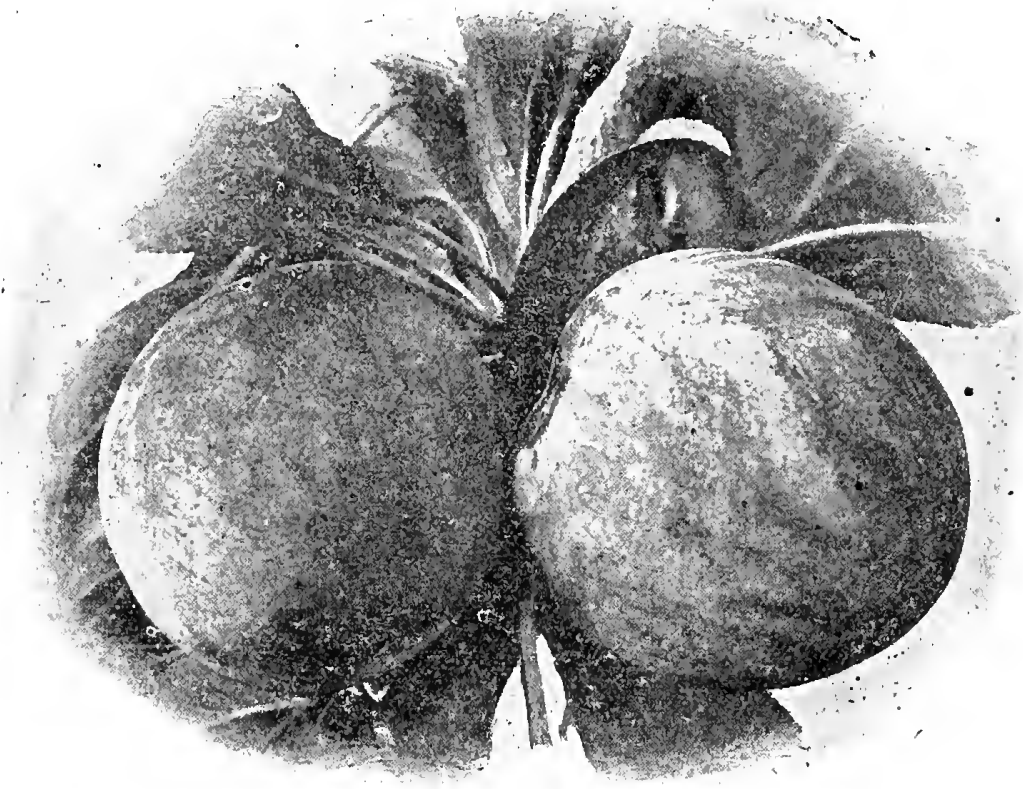

Burbank

Shipper's'Pride. Fruit large; color bluish purple, handsome and showy; flesh firm, of excellent quality; very productive and is a valuable market variety.

Tennant Prune (New). Originated on Pacific Coast. Large, dark purple, blue bloom. Highest quality; bears transportation well and is said to be the best drying prune cultivated. Hardy, vigorous and productive.

Washington (Bolmar's). A magnificent, large plum; roundish, oval, yellowish, crimson dots and blush in the sun; juicy, fine, sweet and good.

Yellow Egg. A very large and beautiful egg-shaped, yellow plum. A little coarse, but excellent for cooking. Tree a free grower and very productive and hardy. End of August.

Yellow Gage. Above medium size, oval, bright marbled yellow; very juicy and rich-fleshed. The tree grows and bears well, and is hardy in fruit and bud. August.

\section{Improved Native Plums}

De Soto. Originated in Wisconsin. Very hardy and productive, bears young; fruit medium size, yellow marbled with red, good quality. One of the best to plant near other varieties requiring fertilization. September.

Forest Garden. Fruit large, orange, covered with purple bloom; skin thin, flesh orange color, good; productive and vigorous. September. Clingstone. Earlier than De Soto.

\section{Japan Plums}

Abundance ( Botan). Beautiful lemon yellow ground, nearly overspread with bright cherry and with a heavy bloom; large to very large, oblong, tapering to the point. Flesh orange yellow, melting, rich and highly perfumed; abundant and annual bearer. Tree a very vigorous, upright grower. Has been thoroughly tested, and is highly recommended.

Climax. One of Burbank's latest and best. Fruit heart shaped, larger than Wickson and more highly colored. Very fragrant, delicious, prolific and a vigorous grower. Ripens about the time of Red June.

Burbank. Large and beautiful, clear cherry red with a thin lilac bloom; flesh a deep yellow, very sweet with a peculiar and very agreeable flavor. The tree is a vigorous grower with large and broad leaves; usually begins to bear the second year after transplanting. Ripens later than the Abundance; end of August.

Hale. New. Very handsome with a bright orange color thinly overlaid with red; flesh yellow, soft and juicy, yet a good keeper; very pleasant peach flavor, valuable as a late variety ripening when other varieties are gone.

October Purple. Large, round fruit; dark, reddish purple; yellow flesh of most superb quality. Ripens middle of September. Its la rge even size, beautiful color and superb quality, make it very desirable for the garden or market.

Ogon. Large, nearly round, bright golden yellow, with faint bloom; flesh firm, sweet, rich and dry. Tree vigorous and hardy. First of August.

Red June. An early ripening Japanese plum; medium to large, roundish, conical, purplish red, handsome; flesh yellow, quality good.

Satsuma (Blood). Large, globular with sharp point. Color, purple and red with bloom; flesh firm, juicy, dark red or blood color, fine quality; pit very small. Just acid enough to be excellent for cooking and preserving. Keeps long and ships well. The tree makes a rapid yet compact growth and yields heavy crops. August.

Wickson. Originated by Burbank. A sturdy upright grower. Fruit remarkably handsome, deep maroon red, covered with white bloom; stone small; flesh fine texture, firm, sugary and delicious. Excellent keeper and shipper; will keep two weeks after ripening.

Willard. Size medium, color red and attractive; vigorous, hardy and productive; very early, about July 15. Will keep in good condition a long time after picking.

Yellow Japan (Chabot). Lemon-yellow ground; nearly overspread with bright cherry and heavy bloom; large to very large; oblong, tapering to a point like Wild Goose; flesh orange yellow, melting, rich and highly perfumed

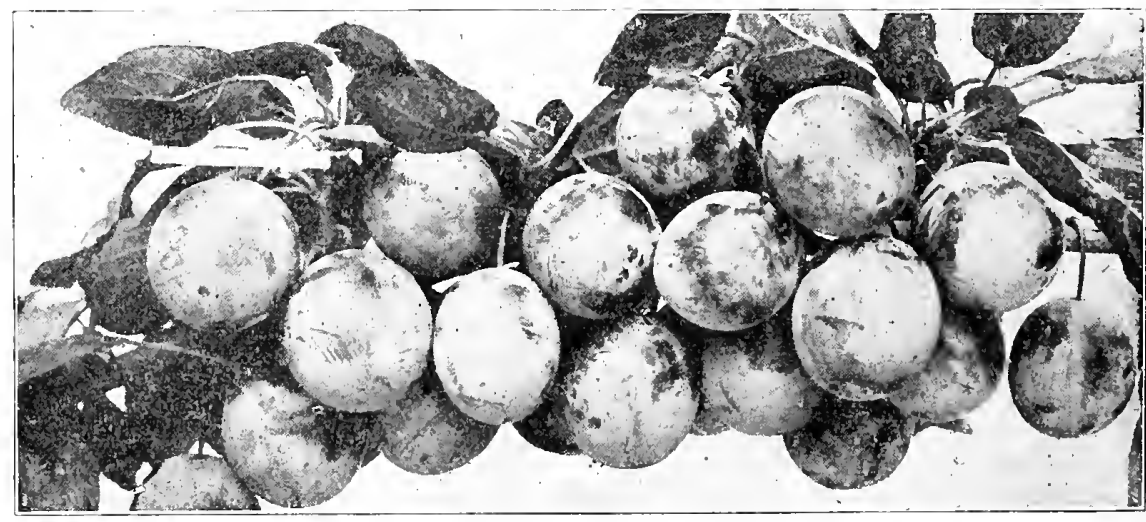

Shropshire Damson Plums 


\section{PEACHES}

The peach tree requires a well drained, moderately rich soil; warm, sandy loam is probably the best.

In order to preserve the continued healthy growth of the tree and the fine quality of the fruit, the peach should have the shoots and branches cut back to one-half the preceding season's growth every year, so as to preserve a round vigorous head; this should be done the last of February, or as early in the spring as practicable. The land should not be seeded to grass, but kept in constant cultivation until August.

The following varieties have been selected out of hundreds, the best only being chosen. They furnish a succession for about two months, commencing the early part of August.

Admiral Dewey. A perfect freestone; flesh yellow and of a uniform color and texture to the pit. Hardy and productive. Early.

Alexander. This excellent variety ripens very early. Large, color dee p maroon, handsomely shaded; flesh firm, rich and good; most excellent shipper. Freestone. Middle to last of July.

Brigdon (Garfield). This remarkable peach originated in Cayuga County, N. Y. It is hardy and the fruit large and handsome and more productive than the early Crawford. The foliage is large and glossy. Flesh yellow, rich and juicy, with a pleasant flavor. Fruit deep orange red, dark red on the exposed side. Middle of September. Freestone.

Bokara No. 3. The hardiest yellow peach yet brought to notice; of fine quality and a heavy bearer; 30 per cent. hardier than any other kind.

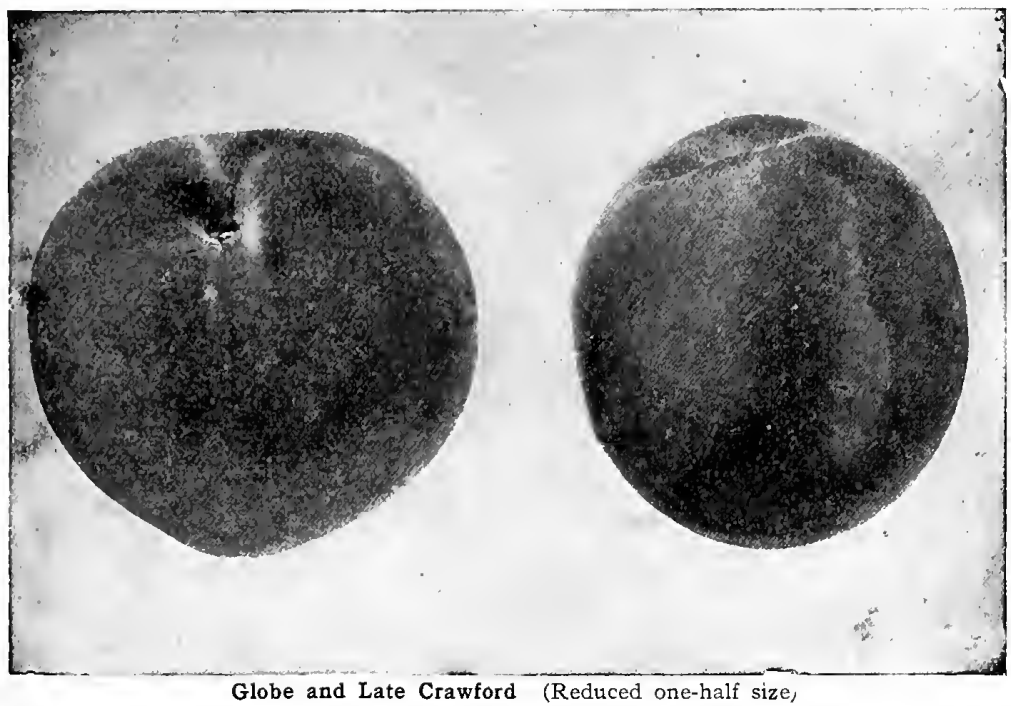

Belle of Georgia. Very large; skin white, with red cheek; flesh white, firm and of excellent flavor; the fruit is uniformly large and showy; tree a rapid grower and very prolific.

Chair's Choice. Fruit of very large size, yellow, with red cheek; flesh yellow, firm and of good quality; tree strong grower and a good bearer. Ripens just before Smock.

Crawford's Early. Very large, yellow, with a fine red cheek; flesh yellow, melting, sweet, rich and very excellent. Tree hardy, vigorous and very fruitful. First of September. Freestone.

Crawford's Late. Very large, yellow, with a dark red cheek; flesh deep yellow, red at the stone, juicy and excellent, with a very rich and excellent vinous flavor; one of the finest of the later sorts. Tree vigorous and productive. Last of September. Freestone.

Champion. An extremely good, early peach. Skin creamy white with red cheek; a perfect freestone, which is a rare thing among early peaches; very hardy, regular bearer. First of August.

Crosby. This is one of the hardiest peaches of good quality yet introduced, and will carry the peach belt several degrees north. The fruit is full medium size, round, oblate. Color bright yellow, beautifully splashed and striped with crimson. The flesh is light yellow and red at the stone, firm moderately juicy and of good quality. It ripens about September 15. Freestone.

Carman. A new hardy rot-proof peach; ripening at time with Early Rivers. Large, round, with pale yellow skin and red blush on sunny side; white flesh, sweet flavor.

Early Canada. Ripens one month before Crawford's Early. Good samples measure over seven inches in circumference; unusually hardy for a peach. Last of July.

Early Rivers. Large, creamy white, with a delicate pink cheek; flesh melting, with a rich flavor. One of the finest of the early peaches for amateur's use and for market. August.

Engle Mammoth. Very large and attractive, magnificent red cheek, high quality. Tree strong grower, very hardy and productive. One of the best canning varieties. Resembling Late Crawford. September.

Early York. Medium size, greenish white, covered in the sun with dull red; flesh greenish white, very tender and melting, full of rich sprightly juice. One of the best early varieties. Tree hardy and productive. Middle of August. Freestone.

Elberta. Yellow with red cheek; flesh yellow, firm, juicy, of high quality, exceedingly prolific and hardy. Very popular and is "THE BEST GENERAL PEACH FOR ALL sections;" follows Early Crawford. The Elberta has received more favorable notices from the fruit and agricultural papers than any other peach.

Fitzgerald. A chance seedling found in Ontario, outside the peach belt, where it has produced regular crops. The fruit is of very large size, pit very small. This promising new peach is of the Crawford type but excels that famous variety in size, hardiness and productiveness. Season same as Early Crawford.

Foster. Large, slightly flattened, color a deep orange red, becoming very dark on the exposed side; flesh yellow, rich and juicy, with a pleasant sub-acid flavor. Freestone. First of September.

Globe. Fruit exceedingly large, globular in form, quite uniform in size; of a rich golden yellow, with a red blush. flesh very firm, coarse grained, but juicy, yellow shaded with a red tinge toward the pit. Freestone. Middle of September.

Greensboro. The largest and most beautifully colored of all the early varieties. Double the size of Alexander, ripening at same time, parts clear from seed when fully ripe. Flesh white, juicy and good.

Golden Drop. The almost translucent golden-colored flesh of this Peach renders it exceedingly attractive in market, where it sells at highest prices. The tree is hardy, bears early and profitably. Late September.

Hill's Chili. Medium size, dull yellow; tree very hardy, a good bearer; highly esteemed for canning. Last of September.

Iron Mountain. Fruit very large, white. Quality good. Very hardy in bud. White inside at pit. Freestone. September.

Lord Palmerston. Fruit very large, skin white with a pink cheek; flesh firm, yet melting, rich and sweet. Last of September. 


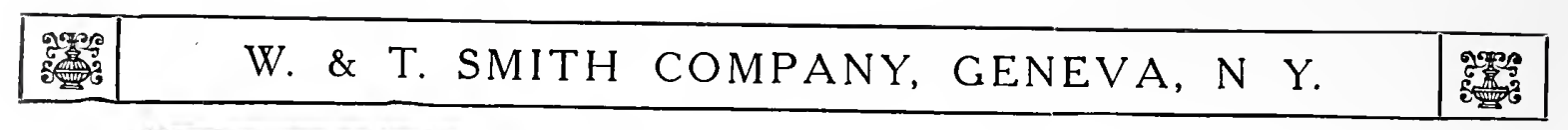

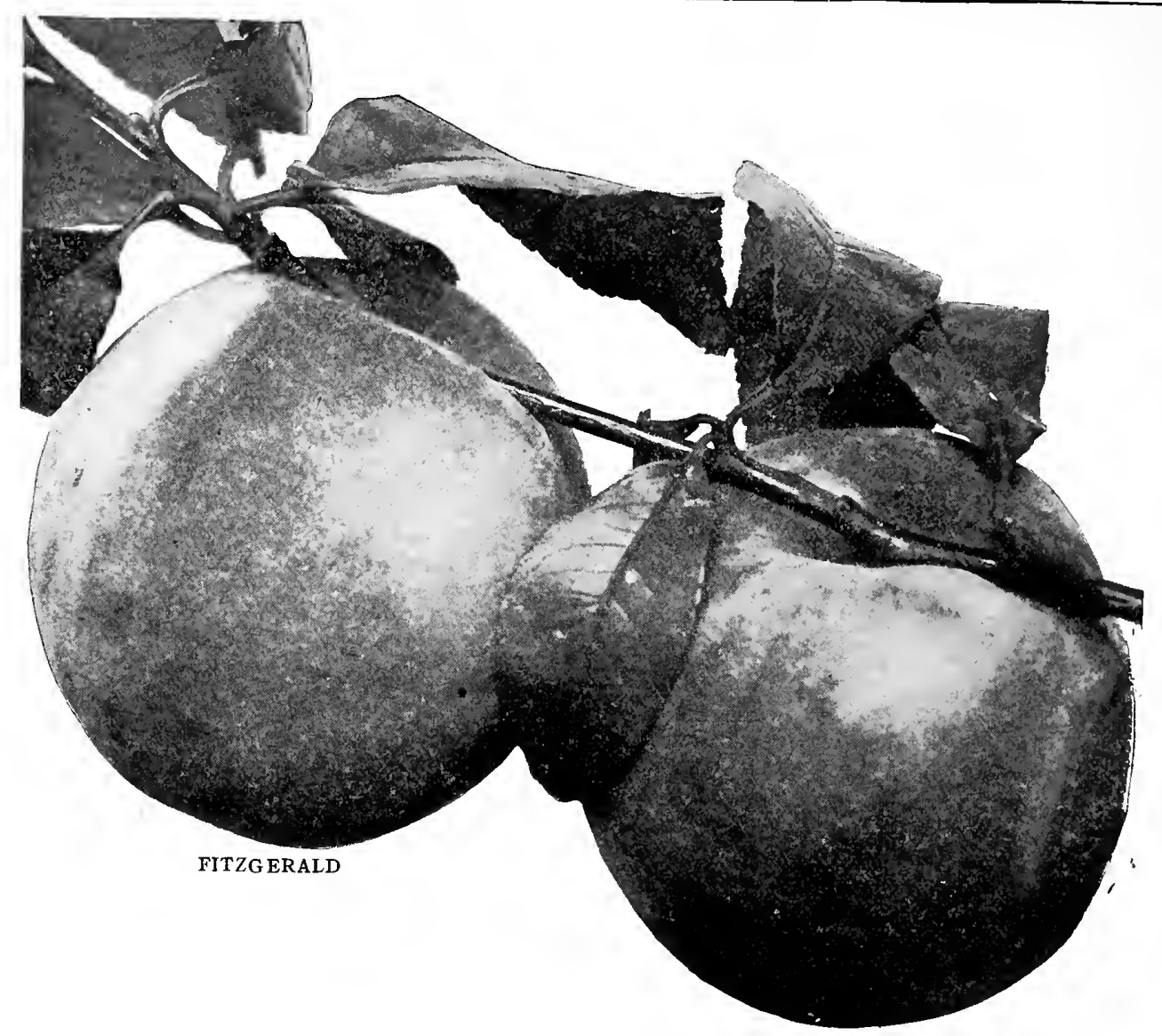

Kalamazoo. Large, golden yellow, with crimson cheek. The thick yellow flesh is of delightful flavor, the pit small. The trce is strong-growing, hardy and productive. September.

Matthew's Beauty. Largely planted as the most valuable succession for Elberta. Large in size, golden yellow, streaked with red; flesh thick, firm, fine. Its good shipping qualities make it an exceedingly valuable variety for market. September.

Mayflower. A most beautiful peach, bright red all over and of good size. Extremely early, coming into bearing even before Sneed. Tree is a strong, thrifty grower and is inclined to overbear. Young fruit must be thinned for best results. A splendid shipper and most valuable market peach.

Morris White. Medium size, dull creamy white; flesh white to the stone, melting, juicy, sweet and rich. Much esteemed for preserving. September.

Mountain Rose. Large red, white flesh; ripens same time as Early York; first quality. Freestone. First of August.

Niagara. Originated in Niagara county, New York, where it has borne heavy crops of uniformly large, delicious peaches every year the past six seasons. The original orchard has 200 trees, and not a tree has blighted or shown any sign of decay, although other varieties in the same orchard have failed to produce crops oftener than two years out of three. Ripens just after Elberta. New.

Old Mixon Cling. Large, pale yellow, with red cheek; juicy, rich and high flavored; one of the best clingstone peaches. Last of September.

Old Mixon Freestone. Large, yellowish white, deep red "cheek; flesh white, tender, with an excellent rich, sugary, vinous flavor. A popular and valuable variety. Tree vigorous and productive. Middle of September.

Prolific. A choice large yellow peach, valuable for succession to Early Crawford, for its fine shipping qualities, its beauty and its good quality. Of strong, thrifty growth, hardy and productive. September.

Salway. Large, skin downy, creamy yellow, with a rich crimson cheek in the sun; flesh deep yellow, stained with red at the stone; juicy, melting, rich, sweet, slightly vinous. Freestone. October.

Smock (Beer's Smock). Large, orange red or yellow, flesh red at the stone, moderately juicy and rich, very productive and a valuable late market variety. First of October.

Steven's Rareripe. Very productive and of high color; ripens immediately after Late Crawford, and continues three weeks. September and first of October.

Stump the World. Very large, creamy white, bright red cheek; flesh white, juicy and high flavored. Productive. Last of September.

Triumph. Earliest yellow flesh peach, with good eating and shipping qualities. Ripens with Alexander, blooms late, sure and abundant bearer; strong, vigorous grower. Fruit good size, yellow.

Wheatland. Fruit large, quality the very best; color a deep golden yellow, a sturdy grower and a good bearer. A most excellent shipper, a valuable market sort. Ripens between Crawford's Early and Late. Freestone.

Willet. Undoubtedly one of the largest and finest peaches grown. Flesh yellow, skin covered with dark red. Specimens have measured twelve inches in circumference. Season September.

Wonderful. Very large, flesh yellow, and will keep a long time in good condition; a good shipper; freestone; pit small; valuable for canning; a strong, healthy grower and very productive, ripening second week in October.

Yellow Rareripe. Large, orange yellow, red cheek; flesh deep yellow, juicy, melting, with a rich and excellent vinous flavor. Tree hardy, vigorous and good bearer. Beginning in September. Freestone.

Yellow St. John. A grand peach, ripening about ten days after Hale's. Nearly as large as Crawford, fully equal in color and of superior flavor; fruit round, brilliant, showy; bears young and produces abundantly. August. 
A most delicious, smooth-skinned fruit, which thrives wherever peaches will grow, but it is liable to be stung by the curculio, and requires the same treatment as plums. Trees good, vigorous growers.

Early Violet. Medium size; yellowish green, with a purple cheek, flesh pale green; melting, rich and highly flavored. Freestone. Last of August.
Elruge. Medium size, pale green, covered with dark red; flesh greenish white, melting, very juicy, with a rich high flavor. Freestone. Beginning of September.

\section{QUINCES}

The quince is well known and highly esteemed for cooking and preserving. One of the most profitable for orchard planting.

The trees are hardy and compact in growth, require but little space, productive, give regular crops and come early into bearing.

They require good deep soil, which should be kept clean and mellow, with an occasional dressing of manure, but do not need severe pruning; a careful thinning out of the old decayed wood will be sufficient.

Keep a vigilant search after the borer, and thin out the fruit if bearing too freely.

Bourgeat. A new variety, of the best quality, tender and good. Ripening shortly after Orange, and keeping till past mid-winter. Largest size, rich golden color, smooth, no creases. Rich velvety skin, with delicious quince odor. Foliage healthy. The strongest grower of the quinces, making tree as large and thrifty as plums and pears, and yielding an immense crop.

Champion. The fruit is very large and productive. Young trees, two years old from bud, are often loaded with fruit. The skin russetted around the stem; below, a lively yellow color. Its flesh cooks tender; season is about two weeks later than the Orange. In growth it is very strong, stout and rugged.
Meeche's Prolific. Fruit said to be larger than the Orange, resembling the Champion in shape and general appearance, though not averaging quite so large; of great beauty and delightful fragrance. Productive and ripens early.

Orange. Large, roundish, bright golden yellow; cooks quite tender, and is of very excellent flavor. Valuable for preserves and market. Very productive. October.

Rea's Mammoth. A seedling of the Orange quince, one-third larger. Fair, handsome, and equally as good and productive. Tree a healthy, thrifty grower.

\section{APRICOTS}

This is one of the most beautiful and delicious fruits, and its value is greatly enhanced by the season of its ripening, between cherries and peaches.

Liable to attack by curculio, and requires the same treatment as that applied to plum trees.

Early Golden. Small; pale orange; juicy and sweet; hardy and productive. First of July.

Early Moorpark. Medium; rich; juicy; very fine.

Harris. Originated in Geneva. Free; perfectly hardy; comes into bearing young, and is very productive. Fruit large, rich golden yellow; ripens middle of July.

Large Early Montgamet. One of the finest early varieties. Large.

Moorpark. One of the largest; orange with a red cheek; firm, juicy, with a rich flavor; very productive. August.

Peach. Very large; orange with a dark cheek; juicy and high flavored.
St. Ambroise. A good grower and very productive of good quality; freestone. Excellent for drying or canning. Ripens about middle of July.

\section{Russian Varieties}

The following varieties are the best that have been brought out; as a class, they are sufficiently hardy, but they are not as desirable as those named in the foregoing list.

Alexander. Fruit yellow flecked with red; very beautiful and delicious. July.

J. L. Budd. Strong grower and profuse bearer; white with red cheek; sweet, juicy, the best late variety. August.

Golden Russian. One of the best of the Russian Apricots; rich, juicy and very fine.

\section{MULBERRIES}

The Mulberry is one of the most valuable of trees. As valuable for shade as for its fruit producing qualities. A wonderfully rapid grower, often growing 6 to $8 \mathrm{feet}$ in one season. Perfectly hardy. The fruit ripens in July and continues for three months. It is rarely picked from the trees, as it falls as soon as ripe, and it is therefore the custom to keep the surface below in a short turf, and the fruit is picked from the green grass. Invaluable for planting in yards where chickens are kept.

Downing. Superseded by New American which is hardier and better.

New American. Tree very vigorous and productive, surpassed by none; possesses a rich, sub-acid flavor; continues in bearing a long time. Fruit one and onequarter of an inch long and nearly half an inch in diameter; color maroon or an intense blue black at full maturity; flesh juicy, rich, sugary.

Russian. Very hardy, shrub-like in form of growth, valuable for feeding silk worms and for fences in severe climates.

Tea's Weeping. See ornamental trees. 


\section{NUTS}

The past few years have witnessed a remarkable development in the planting of nut-bearing trees. Probably no branch of tree cultivation pays larger profits or is as well assured of a profitable market. The immense importations of foreign nuts every year give some idea of the market to be supplied. Few farms but contain land, that, if planted to nut bearing trees, would pay better than anything else to which it could be devoted; the nuts in many cases paying better than farm crops or fruits, while most kinds are making a growth of valuable timber, that will of itself pay a large per cent. on the investment.

Our native nut-bearing trees are admirably adapted for planting in streets, farm lanes, pastures, etc., for shade, ornament and profitable returns.

Butternut (White Walnut). A native tree of medium size; spreading head, grayish colored bark; wood very valuable. Nut oblong and rough; highly prized for its sweet, nutritious kernel.

Filbert, English (Hazel Nut). This is of the easiest culture, growing 6 to 8 feet, entirely hardy, and one of the most profitable and satisfactory nuts to grow; succeeding on almost all soils; bearing early and abundantly. Nuts nearly round, rich, and of excellent flavor.

\section{Chestnut}

American Sweet. A valuable native tree, both useful and ornamental. When grown in open ground it assumes an elegant, symmetrical form; foliage rich and glossy. Nuts sweet, of delicate flavor, and are a valuable article of commerce.

Spanish. A handsome, round headed tree, producing abundantly very large nuts that find a ready market at good prices. Not as sweet as the American.

Paragon (New). A vigorous grower and an early, abundant bearer; nuts very large three or four in a burr and particularly sweet and rich.

Numbo. Nuts very large and of fine appearance, sweet and early to ripen. Tree enormously productive, bearing regularly.

\section{Walnut}

Black. A native tree of large size and majestic form, beautiful foliage. The most valuable of all trees for its timber which enters largely into the manufacture of fine furniture and cabinet ware, and brings the highest price in market. Tree a rapid grower, producing a large round nut of excellent quality.

English. A fine, lofty growing tree, with a handsome spreading head. It produces immense crops of thin shelled delicious nuts, which are always in demand; fruit in green state is highly esteemed for pickling.

Japan. The nuts are considerably larger than the common hickory-nut, and borne in clusters of fifteen to twenty. The shell is a little thicker than that of the English Walnut, which it resembles in a general way. The trees begin to bear when two or three years old.

\section{GRAPES}

Grape vines are very easily transplanted when young, if thrifty plants are used.

Dig holes from eight to ten inches deep and large enough so the roots may be spread naturally, without crossing each other; distribute the finest soil among them and pack firmly.

Cultivate thoroughly through the season; the spring following planting, after the buds swell, cut off all but the two best lowest buds permitting two canes only to grow. In the fall cut one cane four to six feet to bear the next year, and cut one back to two eyes again to form new wood for the following year's crop.

There is a large list of novelties but we name only those that thrive in most localities.

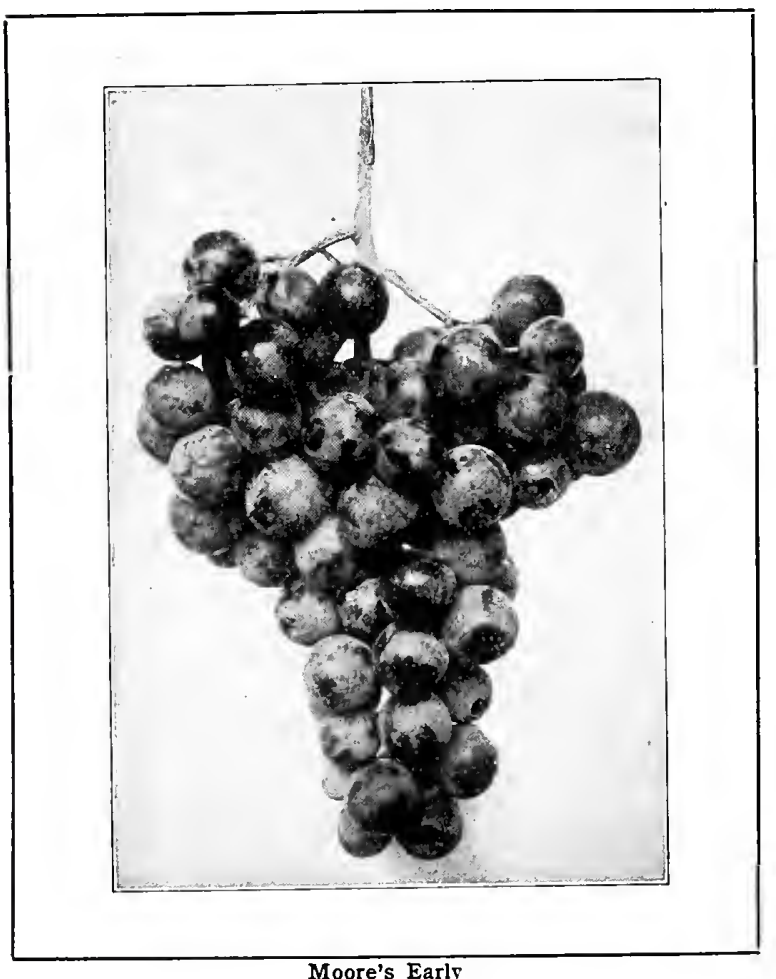

\section{Black and Blue Varieties}

Campbell's Early. A fine new grape. Clusters large, compact and handsome, berries large, nearly round, black, with light purple bloom; flesh firm, but tender; the seeds are few; quality rich, sweet, slightly vinous; a strong and vigorous grower with healthy foliage; it ripens very early; the berries do not drop easily from the clusters, and the fruit keeps a long time in perfection.

Concord. Bunch and berries large, round, black, thickly covered with a beautiful bloom; flesh moderately juicy, sweet pulp, quite tender when fully ripe. Ripens from 10th to 20th of September. Vine healthy, hardy and productive.

Early Ohio. Ripens ten days to two ${ }^{\top}$ weeks before Moore's Early. Bunch large, compact, shouldered; berry medium, covered with heavy bloom; foliage heavy and perfectly healthy. Fully as hardy as the Concord. Very productive, and of good quality. Berry adheres firmly to stem. One of the best shippers.

Isabella. Well known and heretofore popular. Bunch and berry large, dark purple, sweet and rich when fully ripe. Too late for some seasons.

Moore's Early. Bunch and berry large, with a blue bloom; quality better than Concord; ripens ten days before Hartford. Its size and earliness render it desirable.

Worden. Bunches large, handsome; berries large, sweet. Ten days earlier than the Concord, and superior to it in flavor; ripens well in cold localities. Vine very thrifty and vigorous; perfectly hardy and a good bearer. Popular for vineyard and garden. 


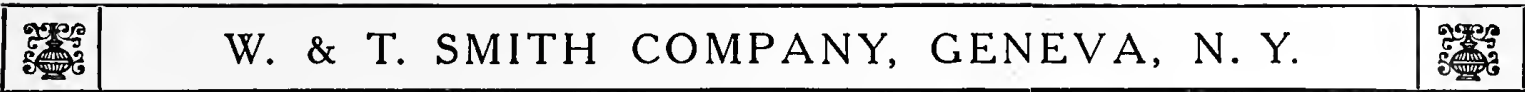

\section{Red Grapes}

Agawam (Rogers' No. 15). Dark red or maroon; bunches compact, very large, berries large; oval, pulp soft, flavor sweet and aromatic. Ripens early; is very attractive. One of the best of the red varieties.

Brighton. Dark red. One of the most desirable of the early red grapes. Very large and handsome. Clusters under favorable conditions are more uniform than those of any other grape. Ripens soon after Hartford. Should be planted near by other varieties as its blossoms do not always fertilize when alone.

Catawba. Bunches large, shouldered; berries large, reddish and sprightly. One of the old and popular grapes, extensively planted in some sections for wine, for which it is valuable, and for its late keeping qualities.

Delaware. Superior as a table grape. Bunch medium, very compact, berries medium round; skin thin, of a beautiful dark red color when fully ripe; flesh tender and juicy, exceedingly sweet. Vine hardy, moderately vigorous and very productive. Ripens early in September.

Salem (Roger's No. 22). Chestnut color; bunch large, short, broad and compact, berry very large, round; flesh nearly free from pulp, sweet, aromatic and well flavored; vine vigorous, healthy and productive. Ripens with Concord.

\section{White Grapes}

Green Mountain (Winchell). Found growing in a garden on the side of the Green Mountains in Vermont, at an altitude of 1400 feet, where it ripened its fruit perfectly. Vine strong, vigorous, healthy, very hardy and productive. Bunch long, compact shoulder, green or greenish white. Skin thin. Pulp very tender and sweet. Three weeks earlier than Concord.

Moore's Diamond. Vine is a vigorous grower, with large, dark healthy foliage, very hardy. It is a prolific bearer producing large, handsome, compact bunches. Color greenish white, with a rich yellow tinge when fully ripe; few seeds, juicy. Berry about the size of Concord and

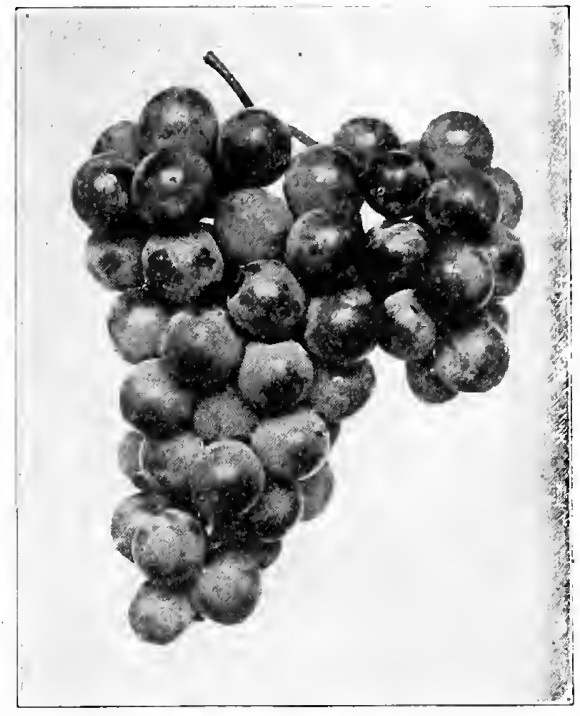

Brighton Grapes

adheres firmly to the stem. It ripens early, usually from Aug. 25th to Sept. 10th. One of the finest of grapes.

Niagara. Vine hardy and strong grower; bunches very large and compact, many weighing fourteen ounces, sometimes more; berries large, skin thin but tough, pale green at first, changing to pale yellow when fully ripe, with a thin white bloom; flesh pulpy, tender, sweet. Ripens with the Concord.

Pocklington. Bunch medium to large, berry large, round, light golden yellow when fully matured; flesh pulpy, juicy. Vine very hardy, healthy, vigorous and productive. Ripens with Concord.

\section{CURRANTS}

Plant in very fertile soil made so by liberal manuring. The tops should be cut back so only three or four branches will grow the first season. Thin out the old wood yearly, opening the bush considerably.

At the first appearance of currant worms they are easily destroyed by sprinkling with a can of water in which

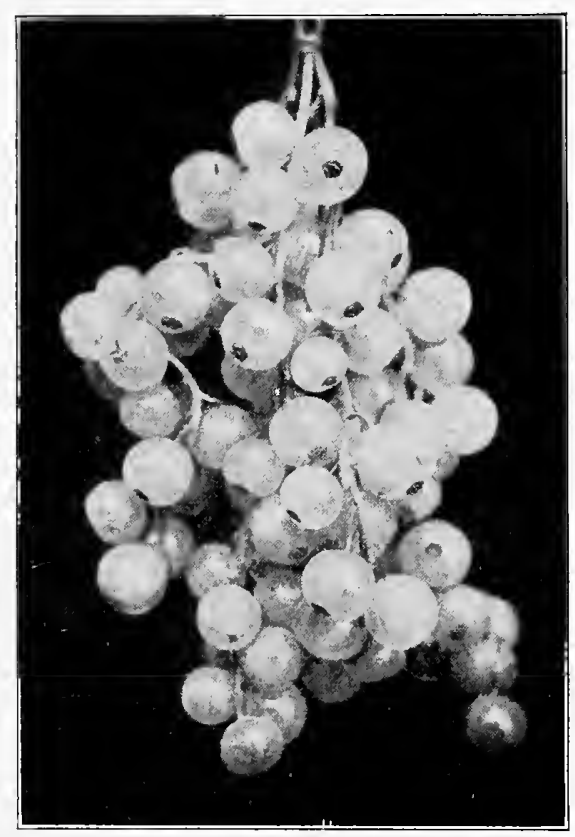

White Grape Currant powdered white hellebore is stirred-(one ounce to three gallons).

Plant in rows five feet apart and three feet in row.

Black Naples. Very large, black, bunches of medium length. Much valued for jellies; strong grower, coarse leaves.

Cherry. Fruit of the largest size, deep red, rather acid; short bunches; growth strong, stout, erect, short-jointed shoots.

Crandall's Currant. A new variety whose yellow flowers make it very useful as an ornamental shrub in the spring. Fruit is large dark colored and has some of the characteristics of a gooseberry.

Fay's Prolific. Has fully sustained ALL the claims that were made for it by the originator when first introduced, and is the best red currant known. It has been widely planted, and has given general satisfaction; fruit very large, bright red, and of excellent flavor, less acid than Cherry. It has a long stem, which admits of rapid picking, and is enormously productive. One of the most valuable fruits of recent introduction. Comes into bearing EARLY.

La Versailles. Very large, red; long bunch of great beauty and excellent quality. One of the finest and best. Very productive.

Lee's Prolific (Black). The largest in berry and bunch, and best in quality and productiveness of any black variety yet introduced.

Perfection. The color is a beautiful bright red; size as large or larger than the Fay; the clusters averaging longer. The Perfection is a great bearer, resembling its parent, the White Grape, in this respect. The quality is rich, mild, sub-acid, plenty of pulp, with few seeds. After three years' trial, this fruit was the first to receive the $\$ 50$ Gold Medal of the Western New York Horticultural Society.

Red Dutch. Deep red, rich acid flavor. An old, well known and fine market sort; good quality; vigorous, upright and very productive. 
Victoria. Large, bright red, long bunch; late in ripening and hangs long on the bush. One of the best; very valuable for its lateness. Spreading growth, very productive.
White Grape. Very large, yellowish white; sweet or a very mild acid; excellent quality and valuable for the table. The finest of the white sorts.

Wilder. A new red currant, fruit large, fine flavored, great yielder, very profitable for market.

\section{ASPARAGUS}

To make a good asparagus bed the plants may be set in the fall or early spring. Prepare a place of fine loamy soil to which has been added a liberal dressing of good manure. Select two-year or strong one-year plants, and for a garden, set in rows 18 to 20 inches apart, with plants 10 to 12 inches in the row.

The roots should be spread and planted so that the crowns, when covered shall be three inches below the surface of the ground. If planted in the fall the whole bed should be covered before winter sets in with two or three inches of stable manure which may be lightly forked in between the rows as soon as the ground opens in the spring.

Conover's Colossal. Highly recommended for its immense size, and being remarkably tender and high flavored.

Donald's Elmira. Color a delicate green, different from other varieties, while the stalks are more tender and succulent. Its mammoth size always commands a fancy price.

Palmetto. It sells at quite an advance over other varieties on account of its mammoth size. Quality not excelled by any.

\section{RHUBARB OR PIE PLANT}

Linnæus-Large, early, tender and fine. The very best of all. This is the great "Wine Plant."

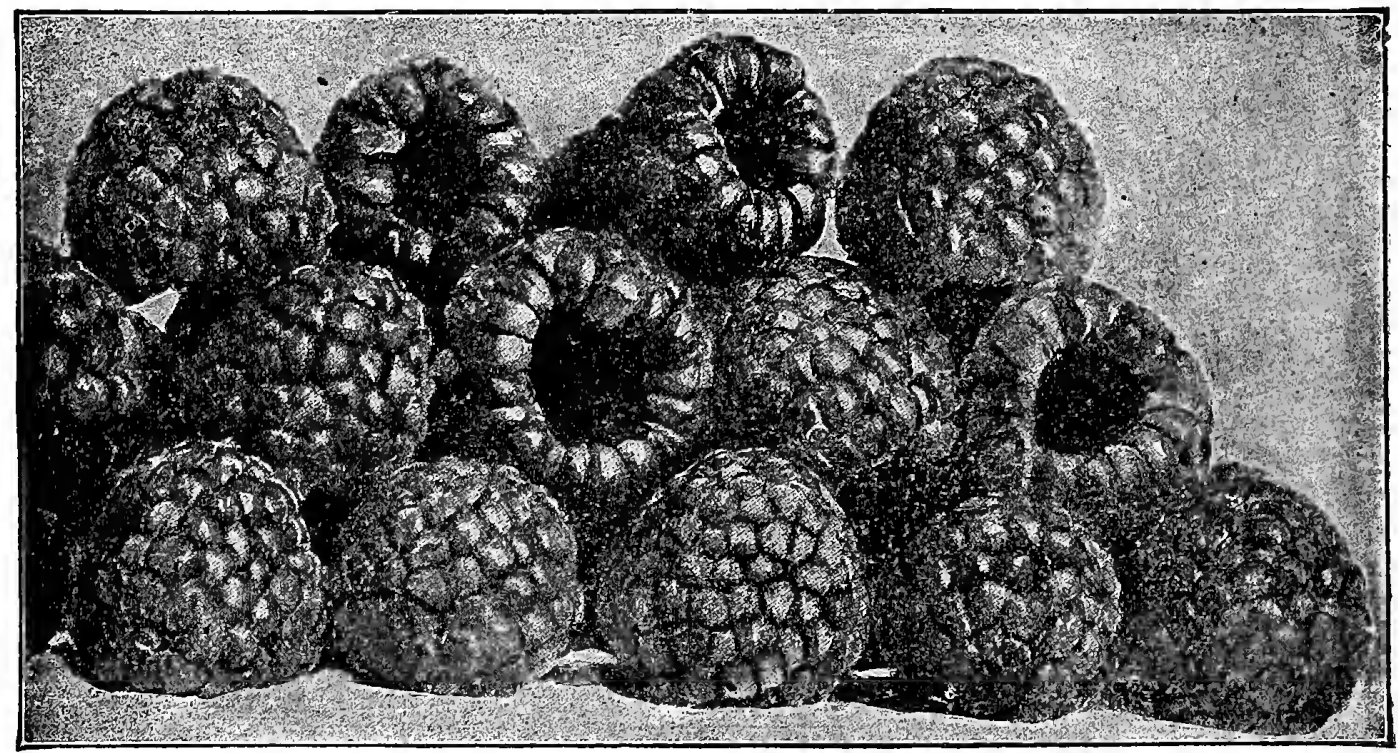

JUNE RASPBERRY

\section{RASPBERRIES}

For field culture raspberries should be planted in rows four to six feet apart, two and one-half to three feet in rows, depending on the character of growth of sorts planted.

The first ycar after planting cut the canes about two feet from the ground and when grown eighteen inches pinch off the ends which will cause them to branch, repeat this when a new growth comes to make stocky plants. The following spring shear off a third of the wood leaving a round bush.

Only five or six shoots should be left on sorts that sucker. Cut off all others.

\section{Red and Purple Raspberries}

Cardinal. The best of the purple raspberries and a most desirable variety for home use. Vigorous in growth, ornamental in appearance and enormously productive.

Columbian. A new variety of great promise. It is a very vigorous grower and very hardy. Fruit purple and delicious for table or canning, and an excellent shipping variety.
Cuthbert, or Queen of the Market. Fruit is large, luscious, and produced in the greatest profusion. Color deep rich crimson; fruit very firm. Ripens from July 10 to 20, and continues a long time in fruit. Entirely hardy and yields heavy crops. Follows the Marlboro in season of ripening.

Herbert. Fruit large, bright red, somewhat oblong, the largest of red raspberries, very hardy. Flavor sweet and juicy. Season five or six days before Cuthbert. 
June. Very excellent red raspberry. A new variety propagated by N. Y. Experiment Station and recommended by them. Very large, prolific and vigorous. Good both for canning and table use.

Loudon. A new red raspberry which originated at Janesville, Wis. Said to be a seedling of the Turner crossed with Cuthbert. Large, broadly conical, beautiful red. Ripens about with Cuthbert, continuing later, and in quality better than that variety. One of the best.

Marlboro. It is a strong grower with strong side arms; it is perfectly hardy. The large size of its dark green foliage is the means of its early, regular and late bearing and extraordinary size of fruit; in color a bright crimson and, unlike others, does not loose its brilliancy when over ripe; of a good quality and very prolific.

Shaffer's Colossal. Fruit very large purplish red, rather soft, but luscious and of a rich, sprightly flavor. A strong grower, hardy and enormously productive. Unequalled for family use, and one of the best for canning; season medium to late.

\section{Yellow Raspberries}

Golden Queen. Large size, great beauty, high quality, perfectly hardy, and very productive; equal to Cuthbert in size of fruit and vigor of growth. Ripens in mid-season. No home garden should be without it.

\section{Black Raspberries}

Cumberland. The bush is hardy, a vigorous grower, and exceptionally productive. Fruit of uniform size, and larger than any known black raspbcrry. Many specimens are from seven-eighths to fifteen-sixteenths of an inch in diameter. In quality it is equal to Gregg, ripening a few days earlier than that variety. It is very firm and a good shipper.

Black Diamond. Berries large, very sweet and pulpy, yet fine for shipping and evaporating. Canes strong and fruitful. Early.

Plum Farmer. Fruit very large, average nearly an inch in diameter, bush a very vigorous grower. Early.

Gregg. Jet black, never falls from the bushes, and of first quality; canes of strong growth, perfectly hardy and immensely productive.

Ohio. The greatest produccr among Black Caps, and for canning or evaporating the most profitable of all. Berry not quite as large as Gregg; plant hardy.

Souhegan. One of the most profitable Black Caps now grown. It is productive, large, jet-black, without bloom, firm, and earlier than any other Black Cap. It is a strong grower and perfectly hardy.

Strawberry-Raspberry (Rubus Sorbifolius). One of the remarkable recent introductions from Japan. A beautiful dwarf raspberry, seeming to be a hybrid between the raspberry and strawberry. Fruit is early, stands well out from the foliage, size and shape of a strawberry, color, brilliant crimson.

\section{BLACKBERRIES}

It is natural for blackberries to grow much stronger than raspberries, but the mode of culture is about the same. Permit three or four canes to grow the first season; pinch back when three feet high. Prune back to four feet. Plant in rows six to seven feet apart, three feet in a row.

Agawam. Fruit medium size; jet-black, sweet, tender and melting to the core. A very valuable variety for HOME use; being sweet throughout as soon as black; very hardy, healthy and productive.

Blower. Large size, jet-black, good shipper, best quality, unexcelled productiveness.

Erie. Fruit very large, excellent quality, handsome and firm and ripens early; fruit uniform both in size and shape. There is no other berry that rivals it in combining hardiness, large size, earliness and productiveness.

Eldorado. The vines are very hardy and vigorous, enduring the winters of the far Northwest without injury. The berries are large, jet black, borne in large clusters and ripen well together.

Rathbun. The tips touch the ground and root, thus propagating themselves like the black cap raspberry. The fruit is borne in clusters; berries very large, color intense black with a high polish; small seeds; flesh juicy, high flavored, sweet and delicious. Carries well to market. In season medium early.

Snyder. A marvel for productiveness; fruit medium size, sweet and melting to the core. Its value is its extreme hardiness, standing the winters in those sections where the Kittatinny and Early Harvest kill down.

Taylor. A good succession for Snyder in cold climates. Ripens its large, luscious berries some weeks later. Vigorous, hardy and fruitful.

Wachusett Thornless. Fruit of medium size, oblong, oval, moderately firm, and less acid than any blackberry we have seen. The plant is said to do equally as well on light and heavy soils. It is also hardy and almost free from thorns.

Wilson's Early. Very large, shining black, retaining its color well after picking, and fine for the table as soon as full colored; quite firm, sweet, rich and good; ripens mainly together, and two weeks before the height of the blackberry season.

\section{Dewberries or Running Blackberries}

Lucretia. The plants are perfectly hardy and healthy, and remarkably productive. The fruit which ripens with the Mammoth Cluster raspberry, is very large, soft sweet and luscious throughout, without any hard center or core.

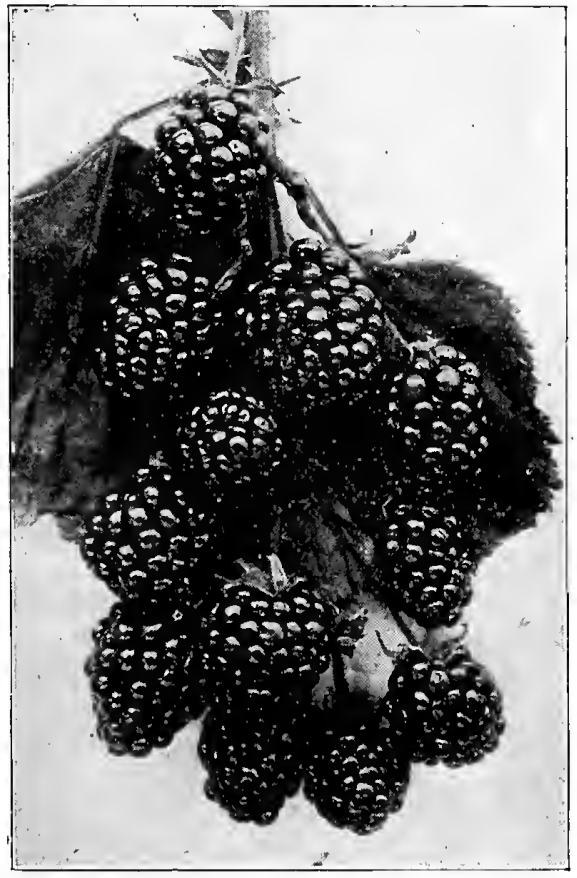

Rathbun Blackberries 


\section{GOOSEBERRIES}

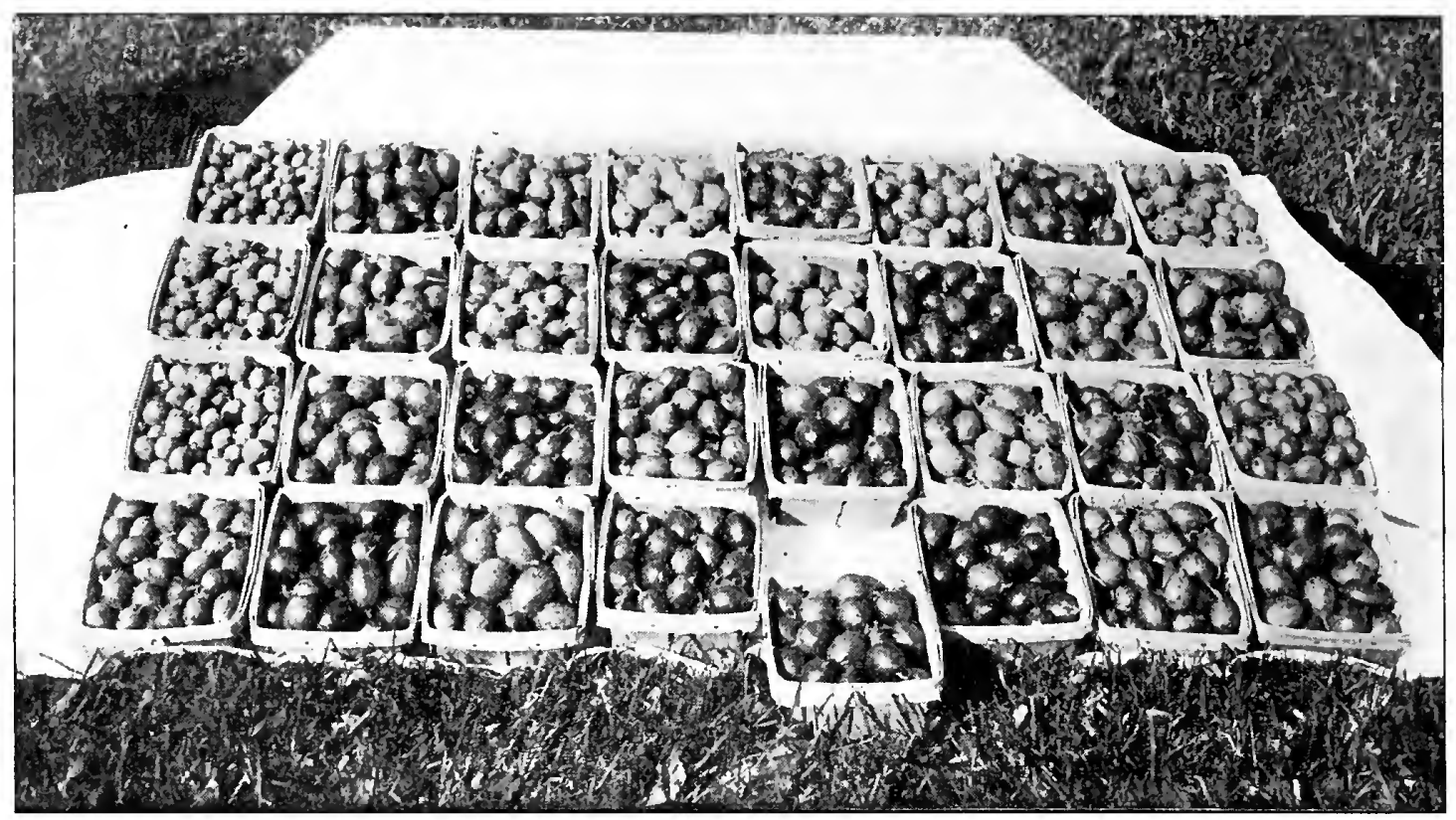

READING FROM LEFT TO RIGHT THE FIRST ROW CONTAINS "DOWNING;" SECOND, FOURTH AND FIFTH "INDUSTRY;" THIRD "WHITESMITH"

Gooseberries thrive well on a variety of soils, if well drained and fertile. The cultivation should be thorough early in the season.

European varieties are of a large size and various colors. The green fruit is sent to the early markets and is profitable.

The best American gooseberries are superior to European sorts in productiveness, hardiness, quality and freedom from mildew; the curse of European varieties and their seedlings is mildew.

Mildew may be kept under control by frequent spraying with potassium sulphide. Bordeaux mixture is not recommended because it spots the fruit. After the fruit is gathered the Bordeaux mixture may be used against the leaf blight.

Chautauqua (European Type). A good grower, fruit large, pale green; quality good. (See cut.)

Downing (American). "The standard of excellence," large, pale green and covered with a white bloom; best in flavor and quality; a strong grower, productive and healthy; valuable for market.

Crown Bob (European). Large, round, ovate, red, hairy fruits, of the finest quality.

Josselyn. Good grower, fine foliage and a very profitable fruiter when compared with any other gooseberry in existence. The freest of all gooseberries from mildew, both in leaf and fruit.

Keepsake (European). The blossoms of this variety are well protected by foliage, so that it is sure to set good crops in any ordinary season. The berries are very large, pale yellow, of good flavor and ship well. Quite productive.
Houghton (American). Fruit medium size, red, thin skinned, juicy, sweet and good in flavor and quality. Very productive.

Industry (European). Bush a strong grower, and the most productive of European varieties; fruit large, dark red, mild, sub-acid, sweet and good flavor; one of the best for market, either green or ripe.

Pearl. The most prolific gooseberry known. One bush produced 2,500 berries. It is free from mildew and is larger than the Downing. The color is light green and quality first class. Being thoroughly tested, we offer it as the best of its class yet grown.

Smith's Improved (American). Color yellow, large, excellent quality, pulp sweet and good.

Whitesmith (European). Fruit large, smooth, thin skin and tender; color yellowish green; sweet and very good. A very desirable variety.

\section{STRAWBERRIES}

Plant strawberries early in the spring on fertile well manured land. For field culture plant in rows three feet apart and one foot in the rows, but for hand culture one foot by two will answer.

Mulching to keep the Fruit Clean. Before the fruit begins to ripen mulch the ground among the plants with short hay or straw. This will not only keep the fruit clean but will prevent the ground from drying and thus lengthen the fruiting season.

A bed will give two full crops and should then be spaded or plowed down, a new one in the meantime having been prepared to take its place.

Notice. Those sorts marked (P.) are pistillate and should have a row of some staminate variety planted near to insure proper fertilization and a crop. 


\section{EARLY}

Bederwood. An exceedingly valuable early strawberry. Conceded to be one of the best early berries for home use and worthy of great praise. It is not only very early but immensely productive. The plant is faultless, of healthy, vigorous growth, and an enormous bearer, perhaps equal to any of the pistillate sorts in this respect. Berries are of large size, of regillar, roundish form, light scarlet, of excellent quality, remaining in fruit a long time.

Clyde. Few strawberries have given better satisfaction in all parts of the country. It is one of the very best medium early varieties-it is a week earlier than Bubach, and very firm; large, bright scarlet berries of fine flavor. The plants are strong growers-deep rooting, stand drought well, free from rust and disease. It thrives particularly well during a dry season-with plenty of sun-bringing its fruit to maturity under surprisingly unfavorable conditions.

Crescent Seedling. P. Good size, a strong grower, very productive; one of the best for market and garden.

Michel's Early. The first variety to ripen here; berry medium to large, roundish, bright crimson, firm, fair quality; plant a strong grower and a good bearer. Valuable on aeeount of its earliness and productiveness. A fine sort to pollenize early pistillates.

Sharpless. One of the best strawberries in cultivation; has held its reputation better than any other variety. Possesses aLL the good qualities looked for in a strawberry; the best variety for the HOME garden. A strong grower, productive and largest size.

Warfield. P. The Warfield is a great plant maker, covering the soil, with only fair treatment. The berries are deep glossy red and are very attractive in market, when well grown. It is red to the center, very firm and much sought for by canners. It has the record of producing under test, the largest crop of any variety of strawberry. To do its best, it must have rich, moist soil and good culture and the plants must be thinned somewhat.

\section{MEDIUM}

Bubach. P. A sterling old sort that combines many excellent qualities; great and uniform size, rich color and quality, extraordinary vigor and fruitfulness, fine foliage that endures the hottest suns. Season early to medium

Dornan, or Uncle Jim. A western strawberry that is attracting much attention for its superior merits. Plants unusually robust, with large healthy, foliage. It is a remarkable drought resister and a reliable producer of extra large berries-very uniformly heart shaped-of a bright beautiful red color and of high quality.

Glen Mary. One of the best, if extraordinarily large size is wanted; good quality and heavy cropper. Cannot be surpassed for home garden and nearby markets. Berries broadly heart-shaped; color dark, glossy crimson; fairly firm and excellent! quality; plant strong and healthy.
Parson's Beauty. A most valuable new early bcrry; very symmetrical and handsome in appearance; dark red color; foliage strong, rank, spotless and frce from rust; heavy bearer and splendid market variety.

Senator Dunlap. This variety is recommended for the average person who wishes to grow strawberries and has had little experience. It is a very vigorous grower and the berries are of good flavor, good canners and excellent shippers. If given only ordinary care the yield will be large and the quality of fruit fair. If the runners are thinned and high culture is given, some of the finest fruits possible to grow can be produced of this variety.

\section{LATE}

Brandywine. One of the very reliable fruiting sorts that can be depended on for heavy crops on a variety of soils. Berries very large, broadly heart-shaped, bright red to the center; firm-fleshed and finely flavored. A valuable late berry.

Gandy. Large and firm berries, of uniform size and shape. On heavy, rich loams the plant is a marvel of vigor and fruitfulness. The best shipping, long-keeping strawberry, as late as the latest of well tested sorts.

Marshall. Berries are beautiful and average very large. It is peerless as an exhibition fruit and for home use. Invariably capturcs the prize wherever exhibited. Although of great size, the fruit is rarely ever mis-shapen. The color is a rich glossy crimson that everyone admircsthe surface color running well into the flesh, and the quality is far above the average. As to productiveness, it will not yield as large a number of berries as some varieties, but when mcasured in quarts or bushels, will be above the average. The plant is faultless, a strong grower, often standing 20 to 22 inches high, rooting deeply and standing drought well. The large luxuriant foliage is sufficient to protect the blossom from late frosts.

Pride of Michigan. This is a very large, late strawberry which is in great favor among the people of its native State, and highly recommended by many New York State growers.

Sample. P. A valuable, large, late variety which promises to be an important acquisition. Sample has scored such a marked success in many places that no progressive grower can afford not to plant some of it. The successful man is he who tests all really promising varieties and quickly finds those the most perfectly suited to his own soil, climate, etc., etc.

Steven's Late Champion. One of the best and most popular late varieties grown. Makes strong, vigorous plants which produce an abundance of fruit. Sends out a great many runners that take root quickly and cover the ground if not restrained. Fruit and blossoms well protected by abundance of foliage. Fruit large, long, slightly flattened. Color is a deep red, the flesh being also red. It ripens all over and is very firm, being one of the best varieties to hold up after picking.

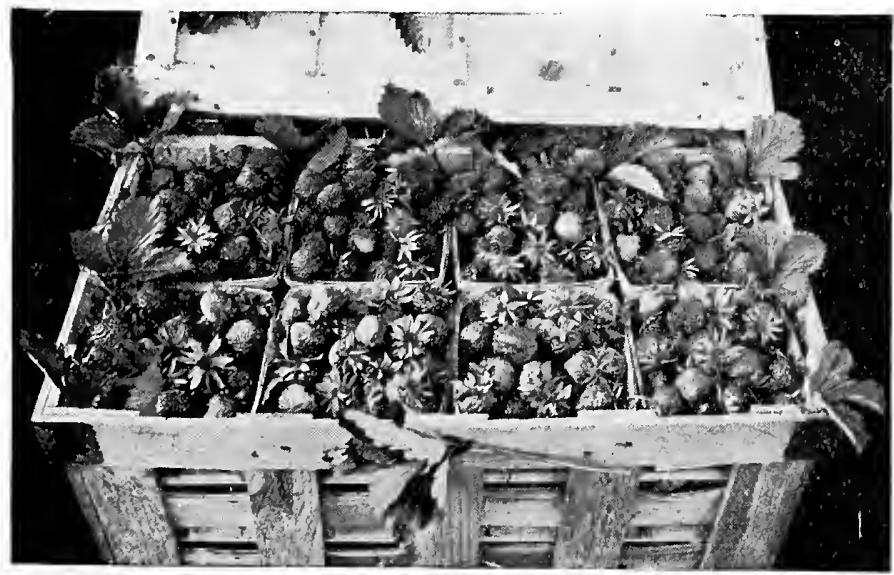

BUBACH STRAWBERRIES 


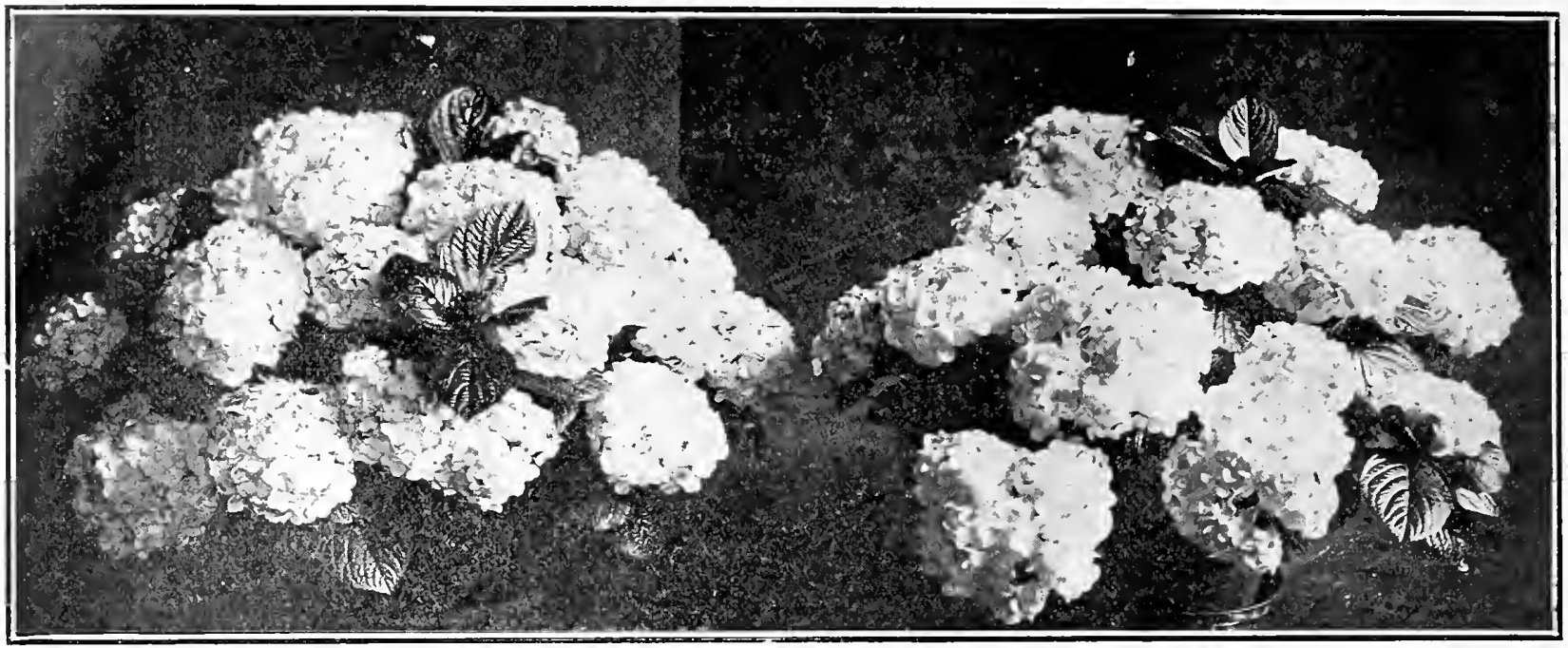

HYDRANGEAS

\section{Ornamental Department}

This portion of our establishment is very extensive, where Avenue and Park trees are cultivated in large blocks; many acres are assigned to the field culture of shrubs, and small growing trees. The borders contain the more delicate shrubs and herbaceous plants.

Our Rose department requires large tracts of land, extensive borders and glass houses where the earliest propagation is begun. People who have never seen a large nursery, little realize the extent of the industry, the amount of experienced labor employed, the thorough cultivation practiced, or the amount of capital necessarily invested to keep the stock up to the highest standard of excellence.

We are yearly adding to our stock new varieties, the choicest selections from our own and foreign countries, and it is our intention to have on our grounds about everything in Ornamental Trees, Shrubs and Roses that is suitable for planting in the United States or Canada, strictly tropical sections excepted.

\section{DESIRABLE TREES TO PLANT}

For Streets, Roads and Avenues. American Elm, Norway, Sugar and Silver Maple, Carolina Poplar, Horse Chestnut, Oriental Plane.

For Driveways Through Lawns and Parks. English Elm, except on the low wet land; Norway Maple, Salisburia, or Ginkgo, Tulip Tree, Magnolia Acuminata, Catalpa Speciosa, American and European Lindens.

Single Specimens of Large Growth, Branched from the Ground. English and River's Beech, Birches, particularly Cut-leaf Weeping; Cut-Leaf Maples, Austrian and Scotch Pines, Norway and Colorado Spruces; Lombardy Poplar, Pyramidal Oak.

Single Specimens of Medium Growth, Branched from the Ground. Imperial Cut-Leaf Alder, Fern-Leaf and Weeping Beech, Purple Birch, Chinese Magnolias, Prunus Pissardi, Flowering Thorns, Hemlocks, White Pines, Siberian Arborvitæ, etc.

Strong Growing Trees of Pyramidal Habit. Lombardy and Bolleana Poplars, Fenn-Leaved Linden, Pyramidal Oak, Pyramidal Arbor Vitæ.

Trees that Thrive in Moist Locations. American Elm, American Linden, Ash, Catalpas, Poplars, Willows and Silver Maple.

Trees that Thrive on Dry Knolls of Poor Soil. Silver-Leaf Maples, Poplars, Birches.

Best Trees for Wind Breaks. Norway Spruce (evergreen), Carolina Poplars and Silver Maples.

Flowering Trees. Magnolias, white and purple; Judas Tree, Peach, pink and white; Laburnum, yellow; Fringe Tree, white and purple; Linden; Horse Chestnut, red and white; Cherry, white and pink; Catalpa: Thorns, red and white.

Cut-Leaved Trees. Imperial Cut-Leaved Alder, Fern-Leaved Beech, Cut-leaved Birch, Wier's Cut-Leaved Maple.

Purple and Scarlet-Leaved Trees. Purple-Leaved Beech, Purple-Leaved Birch, Purple-Leaved Elm, Purple or Blood-Leaved Peach and Plum, Purple Norway and Purple Sycamore Maples.

\section{DECIDUOUS TREES}

It will be noticed that our lists are arranged alphabetically by botanical names with names in common use following. See also index.

Varieties marked $(*)$ are of largest size when fully grown. Varieties marked $(\dagger)$ are of medium height, and varieties marked $(f)$ are of short habit adapted to the lawn, but not for street planting.

\section{Acer. Maple}

*A. dasycarpum (White or Silver Leaf Maple). A fine variety of rapid growth and spreading habit, foliage pendulous and graceful. One of the easiest trees to transplant and is used to advantage where quick effects are desired.

*Wieri laciniatum (Wier's Silver Cut Leaf Maple). A variety of the Silver-Leaved, and one of the most beautiful trees with cut or dissected foliage. Its growth is rapid, shoots slender and drooping, giving it a very graceful habit. The foliage is abundant, silvery underneath. It is one of the most attractive lawn trees. *platanoides (Norway). One of the most beautiful and desirable trees known, of large size, perfect outline, with deep green foliage. Its compact habit, stout, vigorous growth, freedom from disease and insects, render it one of the most desirable trees for the street, park or garden.

* var. Geneva (Purple Maple). A handsome new variety with dark purple foliage holding its color all the season. The very best of all purple-leaved maples.

* var. Schwedlerii (Purple Maple). A beautiful variety of Purple-Leaf Norway with long shoots and leaves of bright purple and crimson color, which change to purplish green on the older leaves. 


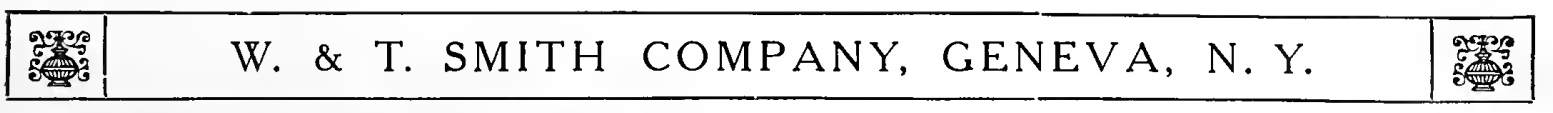

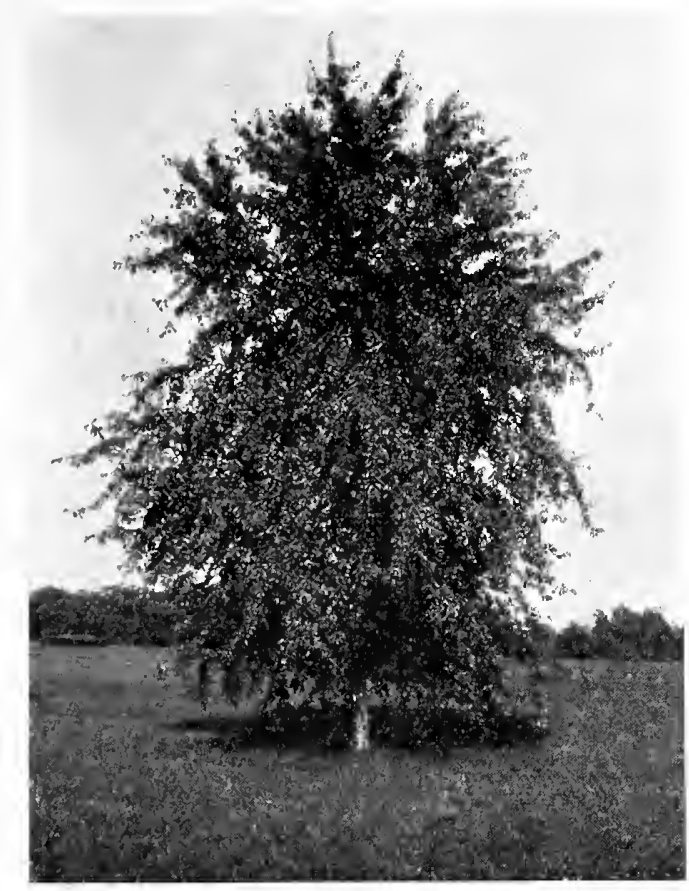

Our Home Grounds. A Weir's Cut-Leaf Maple.

fatropurpureum (Japan Purple-Leaved Maple). Beautiful foliage of blood-red color. It is generally used for planting in groups to obtain a mass of crimson color.

łvar. atropurpureum dissectum (Japan Purple CutLeaved Maple). Form dwarf and weeping. The leaves are a beautiful rose color when young and turn to a dark rich purple. They are deeply and delicately cut giving them a fern-like appearance.

$\dagger$ †rubrum (Red or Scarlet Maple). A native tree of small or medium size, the foliage changing in the autumn to the most gorgeous tints. Red blossoms appear before the leaves.

*saccharum or saccharinum (Sugar, Rock or Hard Maple). A very popular native tree, and for its stately form and fine foliage, justly ranked among the very best, both for the lawn and avenue.

*pseudo platanus (Sycamore Maple). A noble European variety of rapid spreading growth, broad, deep green foliage, and a very desirable shade tree.

*var. purpurea (Purple Sycamore Maple). A variety of the preceding, of good free habit, foliage dark green on the upper surface and red purple underneath.

*Negundo Fraxinus Folius (Ash Leaved Maple or Box Elder). A strong growing, hardy tree of spreading habit. Seeds like a maple and foliage like an ash.

\section{Ailanthus.}

\section{Tree of Heaven}

*A. Glandulosa. From Japan. A rapid growing tree with long, elegant feathery foliage; one of the most distinct of ornamental trees with pinnate foliage. Useful to produce tropical effects.

\section{Aesculus. Horsechestnut}

${ }^{*}$ A. Hippocastanum. (Single White Flowering Horsechestnut). The common or European variety. A fine large tree of compact outline, dense foliage, profuse white flowers, tinged with red, borne in panicles in the spring.

*var. alba Flore pleno (Double White Flowering Horsechestnut). A superb variety, with double flowers in large panicles.

†var. rubicunda (Red Flowering Horsechestnut). Flowers showy red. The leaves are of a deep green.

*glabra (Ohio Buckeye). Leaves smooth, flowers yellow, blooms in May:

†macrostachya (Dwarf Horsechestnut). Smooth fruited horsechestnut. A beautiful low growing shrubby tree with splendid flower spikes in June.

\section{Aralia. Angelica Tree or Hercules Club}

$\dagger$ A. Spinosa. A native plant valuable for producing tropical effects, having prickly stems, pinnate leaves and bearing immense panicles of white flowers in August.

†Japonica. Very much resembles the above.

A. pentaphylla. A pretty Japanese shrub, of medium size and rapid growth; branches furnished with spines; leaves pale green.

\section{Alnus. Alder}

$\dagger$ A. glutinosa (European or Common). Foliage dark green and wedge shape. Makes a large tree 40 to 60 feet and spreading.

var. laciniata (Cut-Leaved Imperial). A fine variety for a large lawn tree. It can be kept in any shape desired by severe pruning.

\section{Betula. Birch}

*B. alba. (European White Birch). A graceful tree, with silvery bark and slender branches. Quite erect when young, but after four or five years' growth assumes an elegant drooping habit.

*var. pendula laciniata (Cut Leaved White Weeping Birch). Deservedly the most popular and beautiful tree known, possessing straight trunk and drooping branches, full of grace and beauty. The outer bark is paper white, leaves light green deeply cut and drooping.

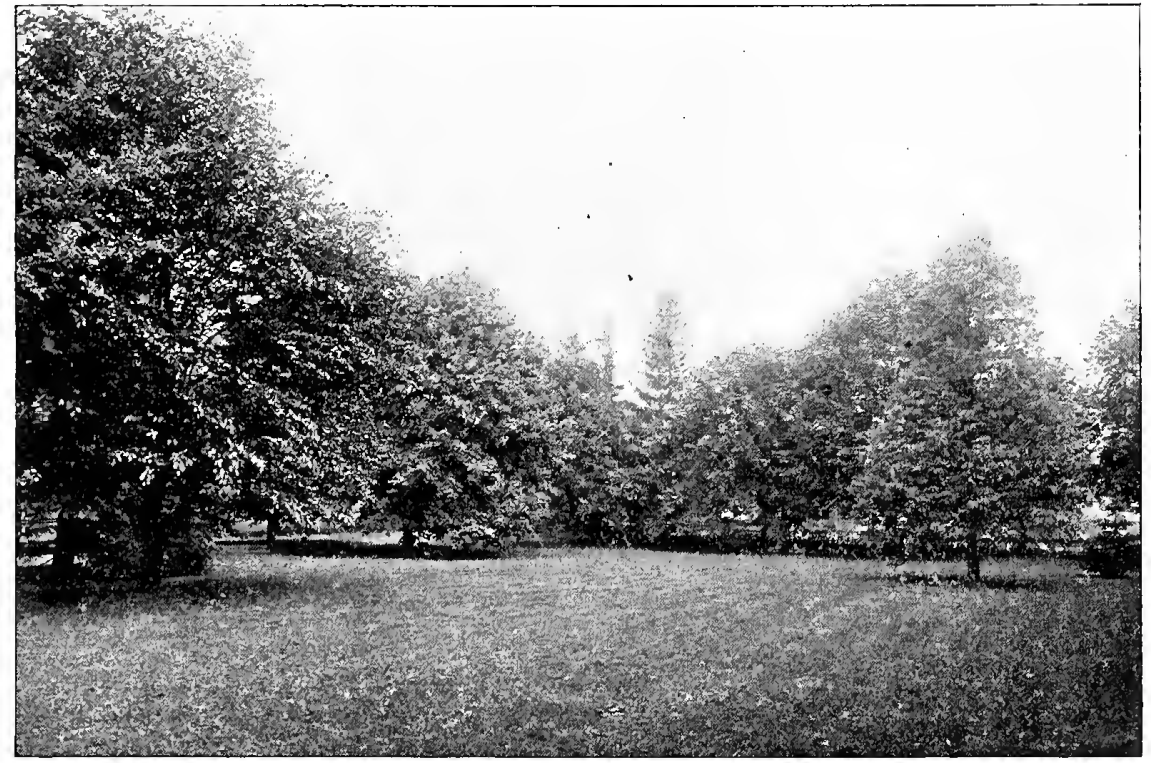

A LANDSCAPE VIEW OF_OUR HOME GROUNDS.

From left to right-Purple Beech, Norway Maple, Norway Spruce, Cut-Leaf Linden. 
*var. atropurpurea (Purple Leaved Birch). A variety possessing the vigorous habit of the birches, and having purple foliage.

*var. fastigiata (Pyramidal Birch). In growth like the poplar, a vigorous and excellent grower, bark white. Very ornamental.

tvar. pendula Youngii (Young's Weeping Birch). A variety of Alba with large shining leaves. Its slender, graccful branches grow to the ground.

*lutea (Yellow or Gray Birch). A native of America. Bark yellowish gray and somewhat silvery.

flenta (Sweet, Black or Cherry Birch). Sweet Birch makes a large, shapely tree, with dark brown bark. Thrives in low as well as high ground.

tnigra (River or Red Birch). An American species of moderate growth, elegant habit with fine foliage and reddish bark.

*populifolia (American White Birch). An American species of rapid growth with triangular, tapering, glossy leaves.

\section{Catalpa}

†C. Bungei. A dwarf variety; it makes an attractive round head. Desirable for small lawns and formal gardens. (See cut on cover).

*bignonioides, var. speciosa (Western Hardy Catalpa). Upright growth, round headed. A rapid growing tree, very ornamental and the timber is valuable for posts and railroad ties.

†var' aurea variegata (Golden Catalpa). A medium sized tree with golden, heart formed leaves. Very beautiful in early summer.

*Kaempferi, var. hybrida japonica (Teas, Japan Hybrid Catalpa). Of spreading habit; flowers white with purple dots; fragrant; a most profuse bloomer; remaining in bloom several weeks.

\section{Cercis. Judas Tree}

łC. Canadensis (American Red Bud). A small growing trec, covered with delicate purple flowers before the leaves appear. Perfectly hardy.

\section{Cerasus. Cherry}

†C. Padus (European Bird Cherry). Racemes of beautiful white flowers in the spring, followed by profusion of berries.

favium flore plena (Large Double White Flowering Cherry). At the period of flowering in May, the flowers are so numerous as to conceal the branches, and present nothing but a mass of bloom.

†Japonica rosea pendula (Japan Wceping Cherry). From Japan. Most rlelicate, graceful, weeping tree.

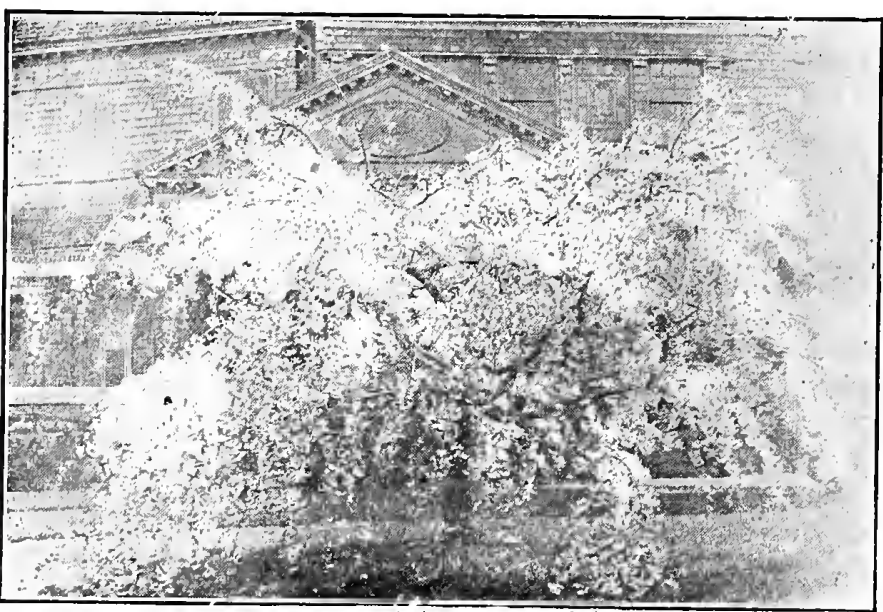

Japan Weeping Rose Cherry.

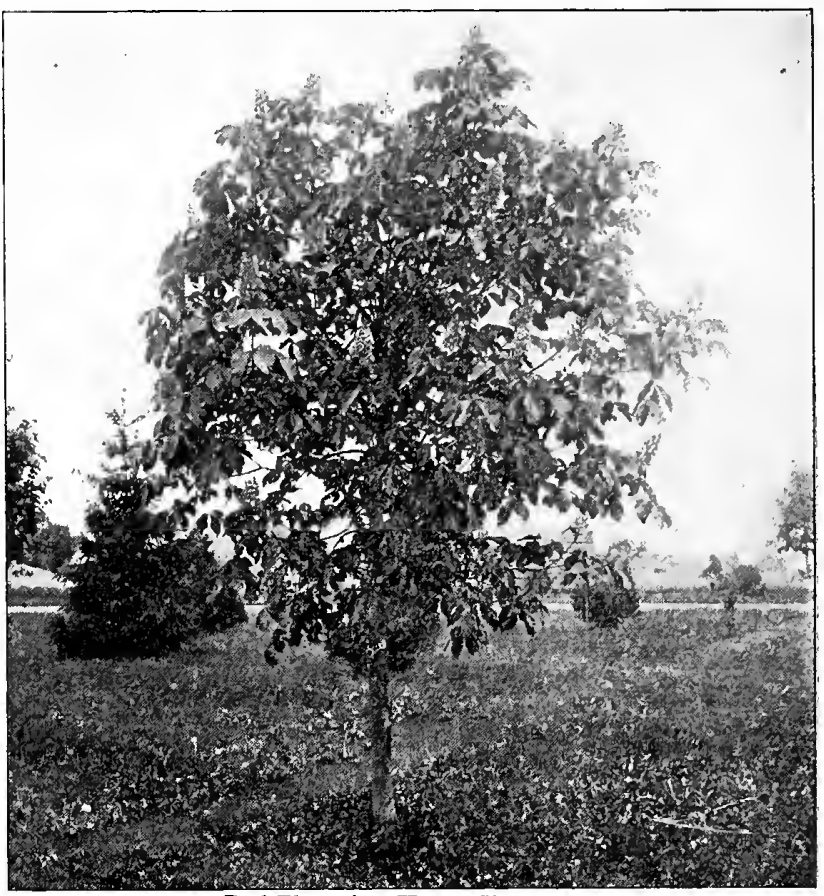

Red-Flowering Horse Chestnut.

Beautiful foliage and a fountain of rosy bloom when in flower.

łpumila Bessyi (Rocky Mountain Dwarf Cherry). A hardy dwarf varicty introduced because of its valuc for fruiting.

Sieboldii flore plena rubra (Double Red Flowering Cherry). Semi double flowers, white, tinged with red.

$\ddagger$ Virginiana (Wild Choke Cherry). This is much like the European variety but is of dwarf growth.

\section{Craetaegus. Thorn or Hawthorne}

†C. oxyacantha (Common English Haw thorne). A shrub or tree of twenty feet. Single white flowers. Good for defensive hedges.

tvar. alba flore pleno (Double White Flowering Thorn). When in bloom it is a mass of elustered, rose-like, white blossoms.

†var. coccinea flore pleno (Paul's New Double Flowering Thorn). Flowers are in clusters, are very double, large and full, and of a deep, rich crimson.

tCrus Galli (Cockspur Thorn). A native thorn having dark colored leaves and horizontal branches, large, red spotted fruit.

†unctata. A well known native thorn with very long, sharp spines of thorns; fruit bright red; valuable for hedges.

coccinea (American White Thorn). A variety with large foliage. White flowers in May, sueceeded by large, scarlet fruit.

\section{Carpinus. Hornbeam}

†C. betulus (American Hornbeam). A native species, growing from fifteen to twenty feet high. In its mode of growth, quite similar to the Beech, but the foliage is thinner and thore irregular in form. Makes a very ornamental and useful hedge.

Americana (American Hornbeam, Blue or White Water Beech). A native species, growing from fifteen to twenty feet high. In its mode of growth, quite similar to the Beech, but the foliage is thinner, and more irregular in form. 


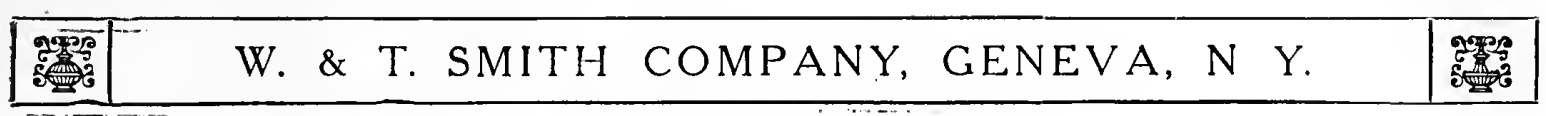

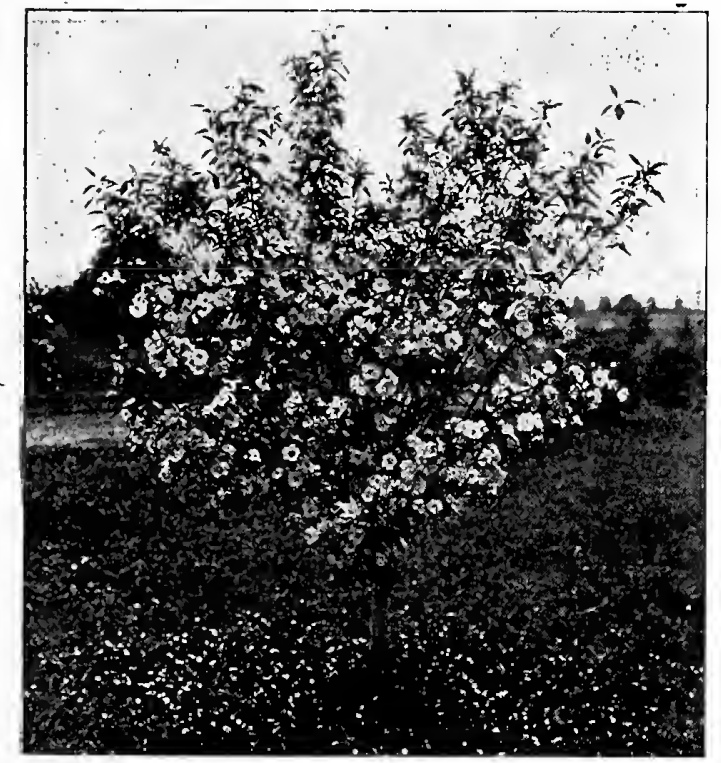

Bechtel's Double-Flowering Crab.

\section{Cytissus. Laburnum}

C. Laburnum (Golden Chain). Native of Europe, with smooth and shining foliage. The name "Golden Chain" alludes to the length of the drooping racemes of yellow flowers, which appear in June.

†Alpinus (Alpine or Scotch Laburnum). A native of the Alps. Also said to be found wild in Scotland. Of irregular, picturesque shape, smooth, shining foliage, which is larger than the English. Yellow flowers in long racemes. Blooms later than the English.

\section{Cladrastis. Yellow Wood}

C. tinctoria, syn. Virgilia Lutea (Yellow Wood). An elegant lawn tree of clean, upright habit of growth with handsome foliage and showy, long clusters of fragrant, pure white flowers produced in June.

\section{Cornus. Dogwood}

See also Cornus under shrubs

†C. florida ruba (Red Flowering Dogwood). Flowers a deep pink color appearing early in May.

fflorida. (White Flowering Dogwood). A beautiful native tree. It has large, showy white blossoms. Very ornamental.

\section{Fraxinus. Ash}

*F. Americana (American Ash). A well known native tree of largest size, thrives in any soil and is suitable for a street or avenue tree.

*excelsior (European Ash). Tree is of rapid growth and spreading habit. Bark grey, foliage pinnate and buds black.

tvar. pendula (European Weeping Ash). The common well known sort; onc of the finest lawn and arbor trees. Covers a great space and grows rapidly.

tvar. aurea (Golden Bark Ash). A variety with yellow bark and black buds. Very conspicuous in winter time.

†var. aurea pendula (Golden Bark Weeping Ash). A beautiful weeping tree; very effective because of its color.

*lanceolata (Green Ash). A vcry hardy and well known variety. Native from Florida to Canada.

\section{Fagus. Beech}

$\lceil$ F. Ferruginea (American Beech). Good in any situation, a very hardy, tall growing, native tree.

${ }^{*}$ F. sylvatica (European Beech). A compact tree attain- ing the largest size, retains its leaves brown and dry throughout the winter.

*var. pendula (European Weeping Beech). A strong growing variety with a fairly straight or upright trunk from which spread straggling and crooked branches; foliage rich, large and glossy.

*var. purpurea (Purple or Copper Beech). Foliage red, purple in early summer, and a tree of symmetrical habit.

*var. purpurea Riversii (River's Purple Beech). A variety of European beech with large, smooth, very dark leaves. The best purple lawn tree known.

*var. incisa (Cut Leaved Beech). An erect, free growing tree, foliage light green and decply cut or incised.

\section{Gymnocladus. Kentucky Coffee Tree}

${ }^{*}$ G. Canadensis (Kentucky Coffee Tree). Tree makes a rapid growth with long feather like foliage, rough bark and stiff blunt shoots.

\section{Larix. Larch}

${ }^{*}$ L. Europæ (European Larch). A rapid growing, pyramidal tree, valuable for timber. Small branches, somewhat drooping, and very delicate in appearance.

\section{Liquidamber. Sweet Gum}

$\dagger$ L. styraciflua (Sweet Gum or Bilsted). A roundheaded tree, with star-like, glossy leaves, turning brilliant red in autumn; very ornamental.

\section{Liriodendron. Tulip Tree}

*L. tulipfera (Tulip Tree). A native tree of the Magnolia order; remarkable for its symmetry, its rich glossy foliage, regularly distributed branches and large tulip-like flowers.

\section{Koelreuteria. Varnish Tree}

$\nmid$ K. paniculata (Varnish Tree). Attractive for its mass of orange yellow flowers in July. It is a native of China, small growing with large pinnate leaves. An unusually good tree for small lawns.

\section{Morus. Mulberry}

$\dagger$ M. alba. (White Mulberry). A native of China. Tree small and of slender, rapid growth. Fruit pinkish white,

†M. var. Downing. Superceded by New American which is hardier and better.

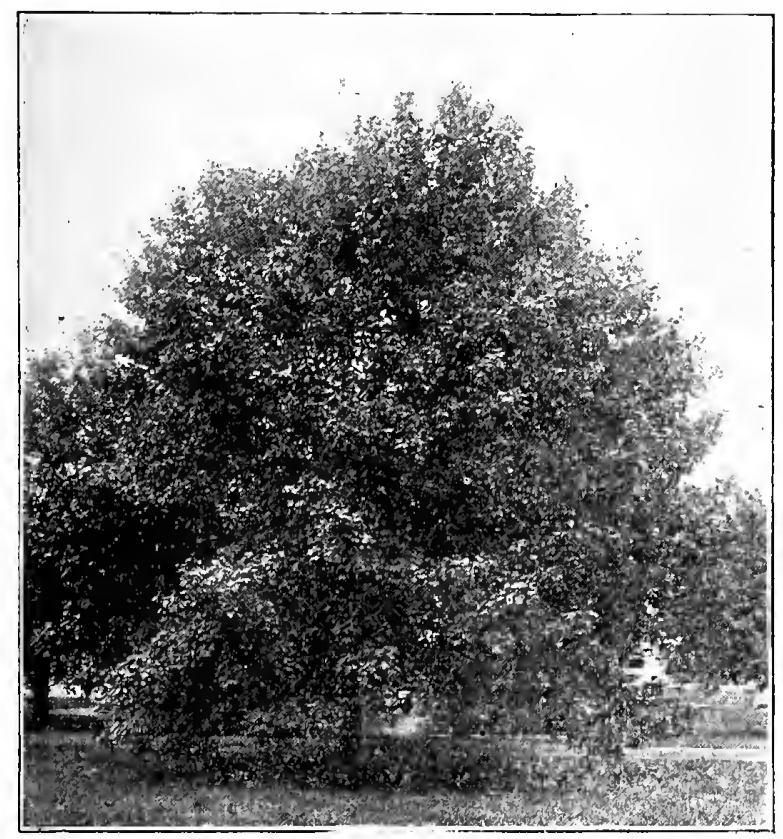

Norway Maple. 
†var. New American. Tree very vigorous and productive, possesses a rich, sub-acid flavor; continues in bearing a long time. Fruit one and onequarter of an inch long and nearly half an inch in diameter.

†tartarica (Russian Mulberry). Very hardy. Develops a bushy shrub-like top, valuable for feeding silk worms, and for fences in severe climates.

‡var. pendula (Tea's Weeping Russian Mulberry). A most graceful and hardy weeping tree. Forms a perfect umbrella shaped head, with long, slender, willowy branches drooping to the ground. Adapted for ornamenting small or large grounds, or for cemetery planting.

\section{Magnolia}

$\ddagger$ M. alba superba (Large Flowering White Magnolia.) A tree of medium size, large white flowers which appear before the leaves.

†Soulangeana (Soulange's Magnolia). Shrubby and branching while young, but becoming a fair sized tree. Flowers white and purple, cup-shaped and 3 to 5 inches in diameter. Foliage large, glossy and massive.

tvar. Lennei (Lenne's Magnolia). A strong, fine grower, and one of the best. Its deep, dark purple flowers are large and cup-shaped, opening in April.

†var. speciosa (Showy Flowered Magnolia). Of shrubby, branching habit, flowers smaller than Soulangeana, and lighter in color; fully a week later; and remain in perfect condition upon the tree longer than those of any other Chinese variety. One of the hardiest.

†conspicua (Yulan or Chinese White Magnolia). A Chinese species of great beauty. The tree is of medium size, shrub-like in growth while young, but attaining the size of a tree. The flowers are large, pure white and very numerous, and appear before the leaves.

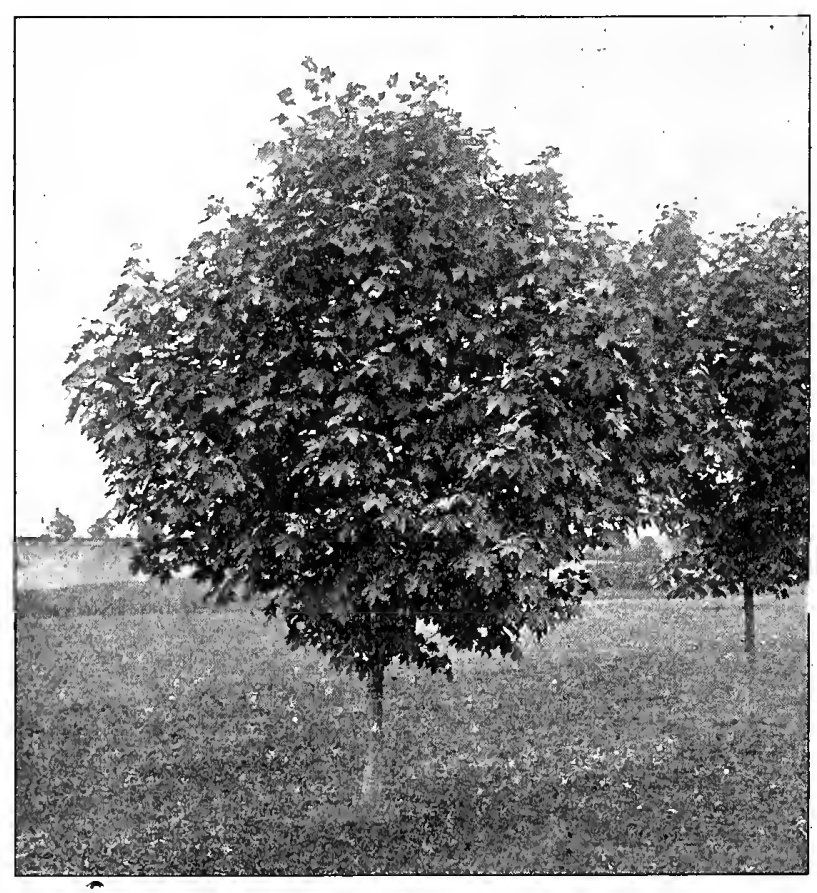

Geneva Purple Maple.

*acuminata (Cucumber Tree). A magnificent native tree with large pointed entire leaves 6 to 9 inches long; blossoms green and yellow, not conspicuous; fruit resembles a green cucumber and the seeds are covered with a bright scarlet shell in autumn.

łstellata, syn. Halleana (Hall's Japan Magnolia). It is of dwarf habit and produces its pure white semi-double fragrant flowers earlier than any other Magnolia.

ttripetala (Umbrella Tree). A hardy, native medium sized tree, with enormous long leaves and large white fragrant flowers, 4 to 6 inches in diameter, in June.

\section{Platanus. Plane Tree}

*P. occidentalis (American Sycamore or, Buttonwood). A well known tree. Leaves heart-shaped at base, the short lobes sharp-pointed.

*orientalis (Oriental Plane Tree). Similar to the above, but leaves more deeply cut. Extensively used for street and park planting.

\section{Persica. Flowering Peach}

$\dagger$ P. flore pleno alba (Double White Flowering Peach). Very ornamental; flowers pure white.

fflore pleno rubra (Double Red Flowering Peach). Flowers double; rose colored.

\section{Pyrus. Crab}

$\dagger$ P. angustifolia (Bechtel's Double Flowering Crab). A medium sized, hardy ornamental tree of great beauty. When in bloom this tree presents the appearance of being covered with roses. Fragrant.

Floribunda. Single flowers in wonderful profusion; beautiful carmine in bud; white when open. May. Fruit very ornamental in autumn.

Floribunda atrosanguinea. Flowers crimson, produced in great profusion. A charming variety. May.

Kaido. Flowers single, white and pink; produced in great profusion; followed with small fruit in clusters; ornamental and fine. May.

Scheideckeri. A fine variety from Germany. Flowers quite double, red in bud, changing to pink or rose color. Yellow fruit.

Spectabilis var. flore alba pleno. (Chinese- Double White-Flowered Crab). Double white fragrant flowers in clusters. May.

$\dagger$ Parkmanii or Halleana (Parkman's Double Flowering Crab). Habit dwarf, a compact grower. Foliage dark green, remaining late on the tree. Flowers very 
double, dark rose, drooping, and retain their color until they drop from the tree.

\section{Pyrus Sorbus. Mountain Ash}

S. Americana (American Mountain Ash). A tree of coarser growth and foliage than the European, and producing larger and lighter colored berries.

aucuparia (European Mt. Ash). A fine, hardy, ornamental tree, universally esteemed, profusely covered with large clusters of scarlet berries.

var. quercifolia (Oak Leaved Mt. Ash). A hardy tree of fine pyramidal habit. Height and breadth from 20 to 30 feet. Foliage deeply lobed; bright green above and downy beneath.

†var. pendula (Weeping Mt. Ash). A variety of European; grafted high it forms an irregular, spreading but drooping head.

\section{Populus. Poplar}

*P. alba Bolleana (Bolleana or Silver Poplar). A very compact upright grower, resembling the Lombardy Poplar; leaves glossy, green above and silvery beneath. The bark of this variety is of a rich green color, giving it a distinct and striking appearance.

*balsamifera candicans (Balm of Gílead). This tree is perhaps the best of the poplars for shade. Well grown trees have the largest and richest foliage of any common poplar.

*monilifera (Carolina Poplar). One of the most rapid growing trees; its branches are spreading, the leaves are large, handsome and glossy. The best of the poplars, and especially adapted to planting in large cities, where it resists the smoke and gas and soon affords a dense shade.

*fastigiata (Lombardy Poplar). Its tall pyramidal form, sometimes reaching 120 feet makes it indispensible in landscape effects for breaking monotony of outline. Its growth is very rapid. Hardy.

\section{Quercus. Oak}

*Q. alba (American White Oak.) One of the finest American trees, of large size and spreading branches.

*bicolor (Swamp White Oak). A massive tree fully grown. It bears quite large, dark green leaves, and acorns of large size. It thrives quite well in either wet or dry situations.

†coccinea (Scarlet Oak). A native species, with handsome, large sinuate toothed leaves, which turn to a bright scarlet in autumn.

*macrocarpa (Mossy Cup or Burr Oak). A native of spreading form. Foliage deeply lobed, and the largest and most beautiful of oak leaves. Cup-bearing acorn, fringed and burr-like.

tpalustris (Pin Oak). Foliage deep green and finely divided. As the tree grows the lower branches droop, till they almost touch the ground. The leaves become of a scarlet and yellow color in autumn. A splendid avenue tree.

fprinus (Chestnut Leaved Oak). One of the finest species; leaves resemble those of the chestnut.

*robur (English Oak). The Royal Oak of England, a well-known tree of spreading, slow growth.

*var. fastigiata (Pyramidal Oak). A tall, rapid, upright growing variety. Foliage bright and glossy.

*rubra (American Red Oak). Very large and of rapid growth, foliage purplish-red in the fall.

\section{Robinia. Locust}

*R. pseudo-acacia (Black or Yellow Locust). A native tree of large size, rapid growth. The flowers are disposed in long pendulous racemes, white or yellowish, very fragrant, and appear in June.

Hispida (Rose Acacia). Is valued for its elegant clusters of rose-colored flowers, which expand towards the close of May, and continue for several weeks. The branches resemble a moss rose.

\section{Salisburia. Maiden Hair}

*S. adiantifolia (Maiden Hair or Ginko). A singular and beautiful tree; foliage yellowish green, curiously lobed and marked with delicate Maiden-Hair fern-like leaves. A valuable tree from Japan. 
or six feet high, it makes one of the most ornamental of small weeping trees.

$\ddagger$ Rosmarinifolia (Rosemary Weeping Willow). A very distinet and ornamental tree with long glossy, silvery foliage; makes a very beautiful lawn tree of medium size.

†regalis (Royal Willow). Largely used for the contrast made by its silvery foliage with greener forms. Very useful and effective.

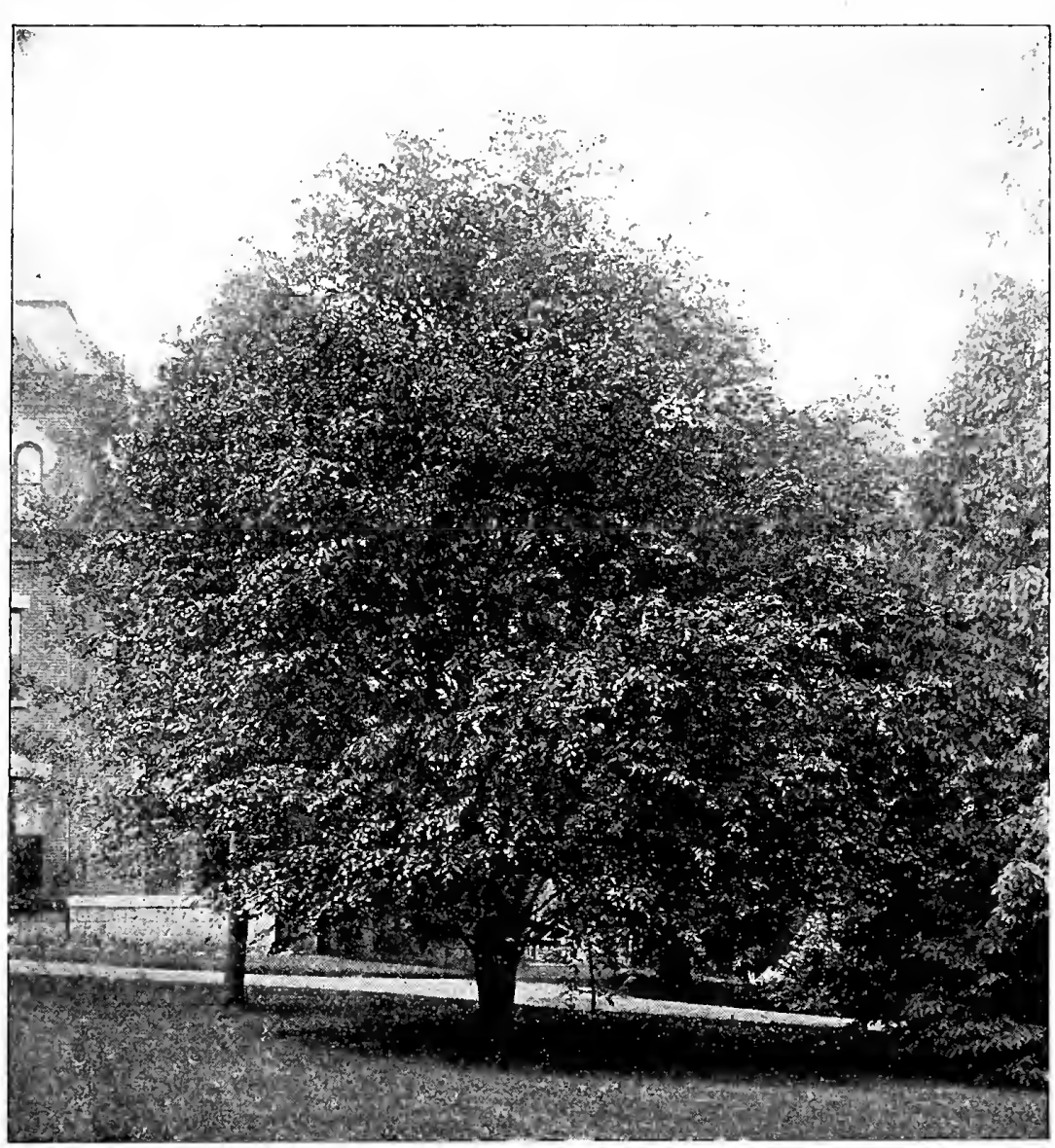

FAGUS PURPUREA RIVERSII-River's Purple Beech.

A specimen on our grounds.

*Thurlow (Weeping Willow). A new variety of stately proportions with graeeful drooping branches and bright, long glossy leaves. One of the hardiest and best of the willows.

†vitellina aurantica (Golden Bark Willow). Handsome. A valuable variety for winter effect, the bright colored golden bark eontrasting harmoniously with other vegetation.

*Wenthworthi (Wentworth's Weeping Willow). A very ehoice varicty with reddish bark.

*Wisconsin pendula (Wiseonsin IVceping Willow). Similar to the Babyloniea, but hardier and is considered valuable on account of its ability to resist scvere winters.

\section{Tilia. Linden}

*T. Americana (American Linden). A rapid growing, beautiful native tree, with very large leaves and fragrant flowers.

*Europaea (European Linden). The broad leaved Linden of Europe, a pyramidal tree with fragrant flowers.

*var. argentea alba (White Silver Leaved Linden). A handsome, vigorous growing tree; leaves whitish on the under side, and having a beautiful appearance when ruffled by the wind. Tips of branches having a drooping tendency.

*var. rubra laciniata (Cut Leaved Pyramidal Linden). A medium sized tree of fine habit. Leaves somewhat smaller than those of the common, and deeply and irregularly cut and twisted. Tree quite pyramidal in form.

\section{Ulmus. Elm}

*U. Americana (American White Elm). The magnificent monarch of our native forests and acknowledged by all to be the finest tree of rapid growth for the lawn, the street or the park.

* var. pendula (White Weeping Elm). A variety of our common Elm in which the weeping habit is much more evident. Its graceful branches drooping. down to the ground. Top grafted.

*campestris (English Elm). A superb tree of strong growth, upright or spreading habit, delicate branehes, small leaves deeper cut, darker and more numerous than the American varieties: a fine street, park or lawn tree.

†var, suberosa (Cork Barked English Elm). A tree of fine habit, young branehes very corky, leaves rough on both sides.

*var. stricta purpurea (Purple Leaved Elm). Very erect in growth, with slender branches, densely clothed with dark purple grcen foliage early in the season. One of the best.

* Montana (Scotch or Wych Elm). A spreading tree of strong growth, very large leaves and smooth bark.

*var. Huntingdoni (Huntingdon Elm). Of very erect habit, and rapid vigorous growth. Bark clear and smooth; one of the finest clms for any purpose.

*var. superba (Blanford Elm). A tree of noble growth. Smooth, gray bark and large, dark green foliage. An elegant shade tree.

†var. pendula (Camperdown Weeping Elm). A very strong, beautiful variety, usually grafted high and the top spreads outward and downward. Very popular and valuable for the lawn.

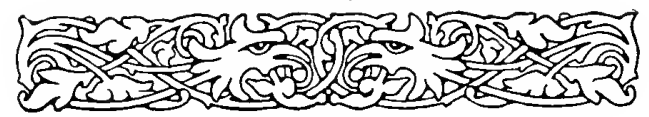




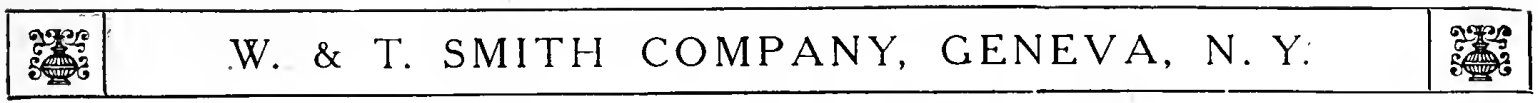

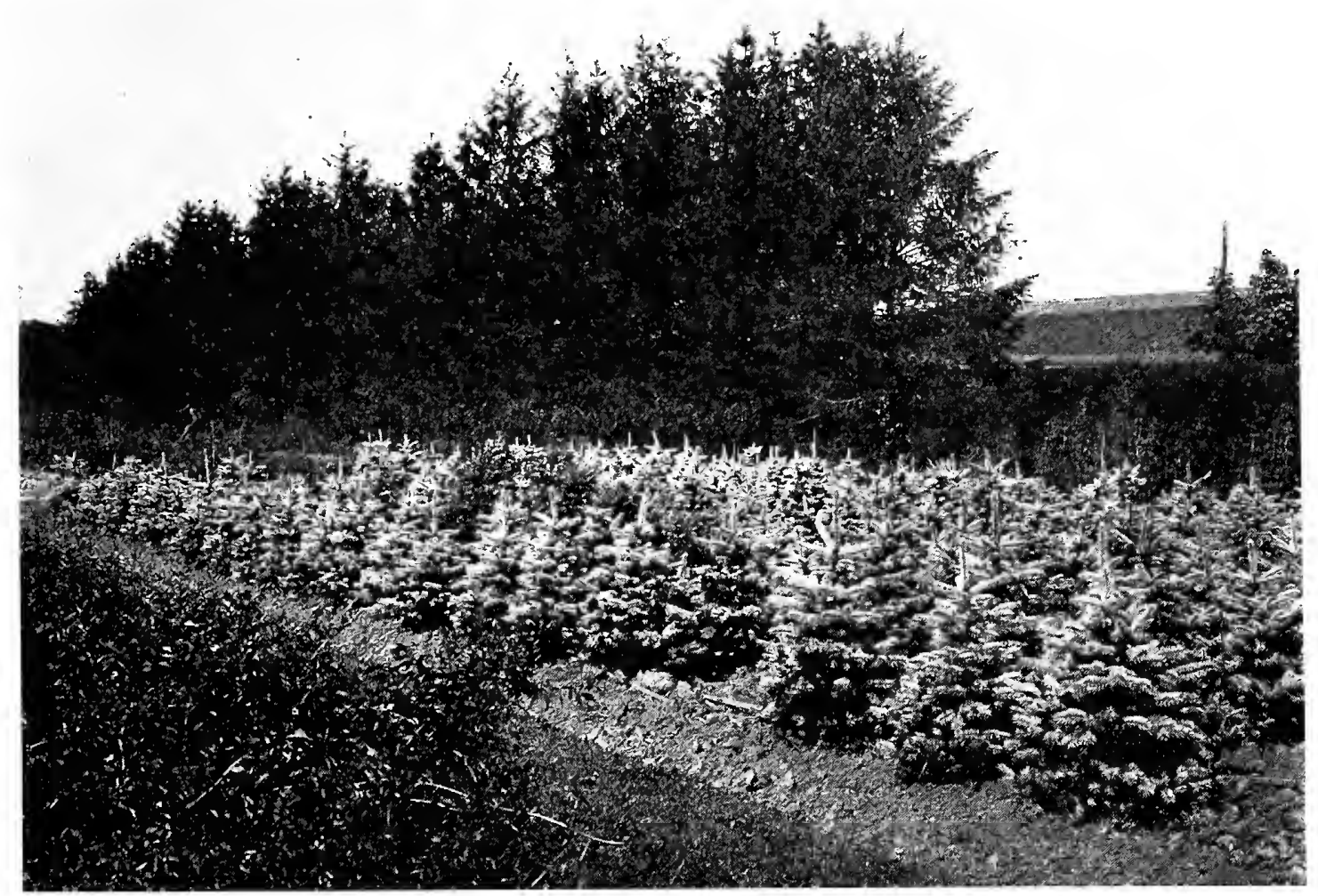

HOME GROUNDS

Norway Spruce Windbreak-Koster's Blue Spruce in Foreground.

\section{CONIFEROUS EVERGREENS}

The following evergreens are mostly very hardy, and particularly adapted to our Northern and Western climates. Many of these make the most ornamental hedges and screens.

\section{Abies. Fir}

A. balsamea (Balsam Silver Fir). A very regular symmetrical tree, assuming the conical form even when young; leaves dark green above, silvery beneath.

Canadensis (Hemlock). An elegant pyramidal tree with drooping branches and delícate foliage; distinct from all other trees. It is a bcautiful lawn tree and makes a highly crnamental hedge.

Concolor (Concolor Fir). A distinct variety with yellowish bark on young branches, foliagc long and light green. A handsome tree, none bettcr.

Nordmanniana (Nordman's Silver Fir). Brought from Crimean mountains, pyramidal and compact; foliage heavy dark green, glossy on upper side and slightly blue and silvery on the under side of the numerous leaves.

Nobilis (Red Fir). A native of the Cascade mountains of Washington and Oregon, where it grows frequently 250 feet in height and six to eight feet in diameter.

Douglasii syn. Pseudo tsuga taxifolia (Douglas Spruce or Red Fir). From Oregon and Washington. It' grows to a height of 200 to 350 feet, with a diameter of six to twelve feet. Conical form, spreading branches, leaves light green above, glaucous beneath.

Veitchii (Veitch's Silver Fir). Resembles the Nordmann's Fir, though the silvery tint is more pronounced. It is hardy and makes one of the grandest of specimens. Foliage dark and massive.

\section{Cupressus. Cypress}

C. Lawsoniana (Lawson's Cypress). A beautiful evergreen from California, with delicate fern-like foliage. Hardy in dry ground. lutea (Yellow or Golden Cypress). Of compact habit, with young growth, clear yellow.

argentea (Silver Cypress). Of slender habit with very glaucous almost silvery foliage.

\section{Juniperus. Juniper}

Juniperus Chinensis argentea or foemina variegata. Bluish green foliage, very dense, interspersed with silvery white.

J. communis Hibernica (Irish Juniper). Very erect and tapering in its growth, forming a column of deep green foliage; a pretty little tree or shrub, and a general favorite.

communis Suecica (Swedish Juniper). A beautiful pyramidal, hardy evergreen with light or yellowish green foliage. It is quite hardy.

var. tamaricifolia (Creeping Savin). Vd. Quite prostrate, creeping over considerable space, fine for rocks, walls and dry places.

Sabina (Savin Juniper). A low, spreading tree, with handsome, dark green foliage; very hardy, and suitable for lawns and cemeteries.

Pyramidal Juniper (See Thuya).

Virginiana (Red Cedar). Tapering form, bright, rich green foliage.

\section{Picea. Spruce}

P. alba (White Spruce). A native tree of medium size, varying in height from 25 to 50 feet; of pyramidal form; foliage silvery gray, and bark light colored.

Alcocquiana (Alcock's Spruce). A Japan tree of the greatest value. It is hardy and retains its foliage well, being always of good form. The silvery tint of the lower 


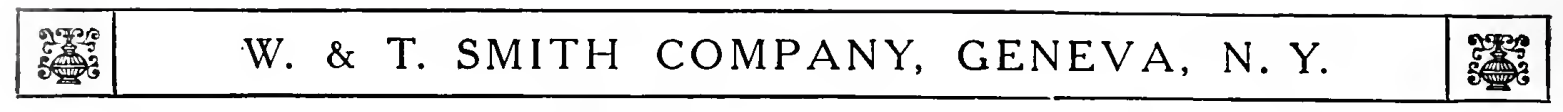

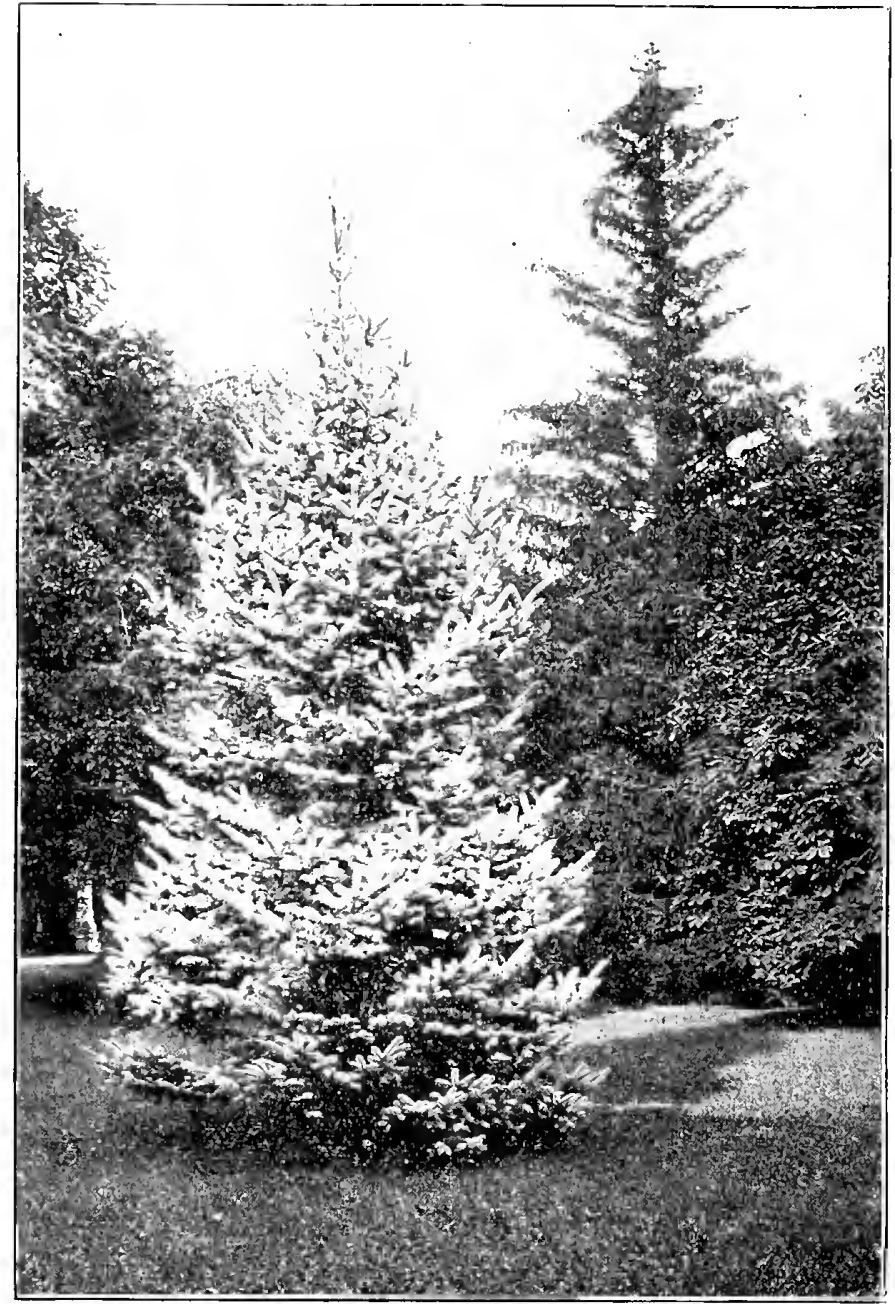

Koster's Blue Spruce.

Norway Spruce

leaf surface is in brilliant contrast at all times with the deep green above.

Doumetti. Like the above, but having bluish gray needles. A beautiful and attractive, diminutive tree.

excelsa (Norway Spruce). A lofty tree, of perfect pyramidal form remarkably elegant and rich, and as it gets age, has fine graceful, pendulous branches; it is exceedingly picturesque and beautiful. Very popular and deservedly so. One of the best evergreens for hedges and wind breaks.

var. inverta (Weeping Norway Spruce). A pendulous variety of the Norway Spruce with larger and brighter foliage than that of the species. The lateral branches of the large trees are as drooping as a willow.

var. pygmea (Dwarf Spruce). A dwarf, compact spruce, with short crowded branches, round form.

orientalis (Eastern Spruce). From the shores of the Black Sea. A handsome tree, tall and compact, and remarkable for its graceful habit and slender foliage. Needs protection here while young.

pungens glauca (Colorado Blue Spruce). A most beautiful variety discovered and disseminated from the Rocky Mountains, it is the nearest blue of any evergreen, very distinct in foliage and growth; fine compact habit. It is in great demand as a lawn tree throughout the eastern states where fine specimens are established proving it the best of all evergreen trees for the lawn. Foliage rich blue or sage color.

var. Kosteriana (Koster's Blue Spruce). A selected strain of the bluest form from the Colorado Blue Spruce. Very blue.

\section{Pinus. Pine}

P. Austriaca (Austrian or Black Pine). A remarkably robust, hardy, spreading tree; leaves long, stiff, and dark green; growth rapid.

Cembra (Swiss Stone Pine). Of thick, regular growth, foliage resembling the White Pine and quite silvery.

Mugho. (Dwarf Mugho Pine). An upright, small, beautiful pine bush.

sylvestris (Scotch Pine). A fine, robust, rapid growing tree, with stout, erect shoots and silvery green foliage.

strobus (White Pine). The most ornamental of all our native pines; foliage light, delicate or silvery green; flourishes in the poorest soils.

\section{Retinospora}

R. filifera (Thread-Branched Cypress). Bright green foliage. Weeping habit.

var. aurea. Golden branched form of the above.

obtusa. Beautiful fern-like branches, more or less weeping. Foliage bright green.

var. aurea. Bright golden foliage.

pisifera (Pea-Fruited Cypress). Bright green, pendulous branches.

var. aurea. Rich golden yellow. Very distinct.

plumosa. Foliage bright green. A beautiful evergreen.

var. aurea. Golden branched; compact, upright habit. One of the most popular.

squarrosa. Foliage silvery. Very beautiful.

\section{Taxus. Yew}

T. baccata (English Yew). A very fine pyramidal variety with dark green foliage; hardy and desirable.

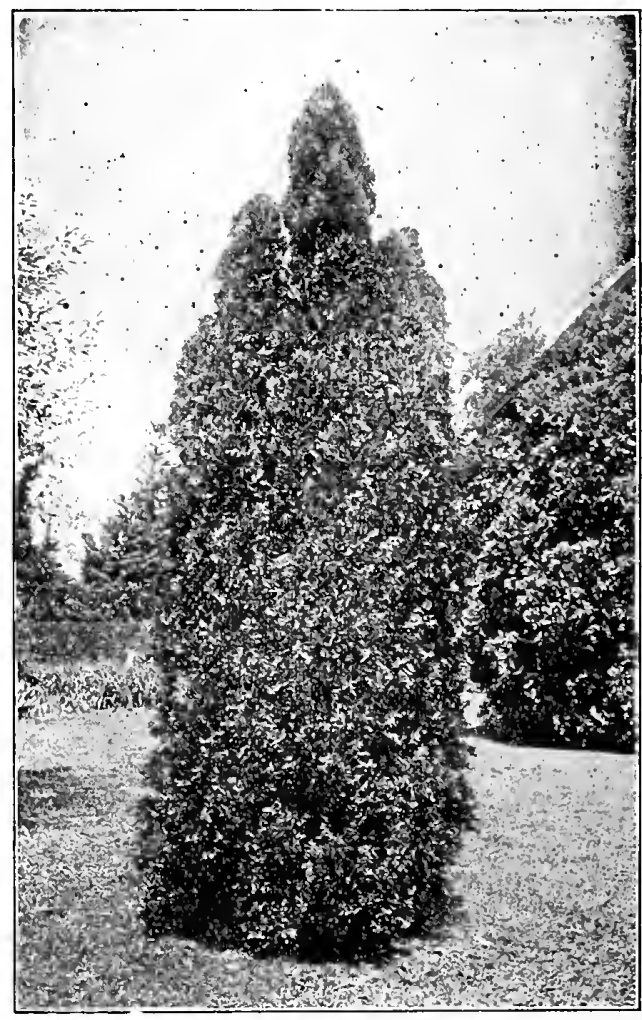

The Pyramidal Arbor Vitae 


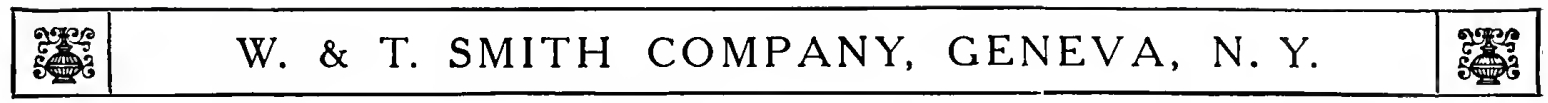

T. var. Washingtoni. The best lof the golden Yews; handsome and rare.

T. cuspidata (Abrupt-leaved Japanese Yew). Upright growth and dense, very dark foliage. Valuable because it is especially hardy and rich in appearance.

T. var. brevifolia. A very handsome form of the above and hardier. We consider it the best variety to plant in New England.

T. Canadensis (American Yew). A low, weeping, broad-spreading bush, dark green foliage and crimson berries. Entirely hardy and very valuable for surfacing beds or forming groups.

var. fastigiata (Irish Yew). A strictly pyramidal form with upright branches, dark glossy green.

\section{Thuya. Western Arbor Vitae}

T. occidentalis (American Arbor Vitae). This is the finest evergreen for hedges. It is very hardy, and easily transplanted. It grows rapidly and with little care, soon forms a most beautiful hedge.

var. compacta (Parson's Compact Arbor Vitae). Habit of growth dense, foliage deep green, very fine.

var. Ellwangeriana. Low, broad pyramid, with slender branches, clothed with two kinds of foliage.

var. Geo. Peabody. A dwarf, dense-growing golden variety, holding its color all summer. One of the best for general culture.

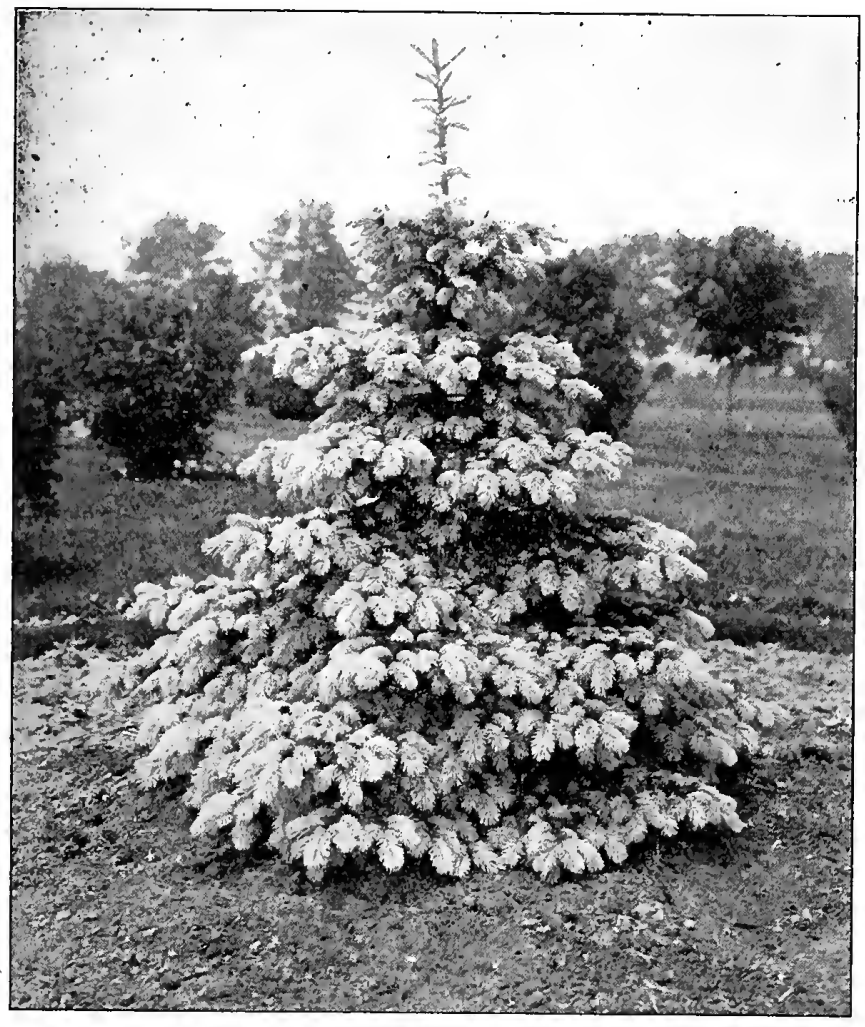

Concolor Fir

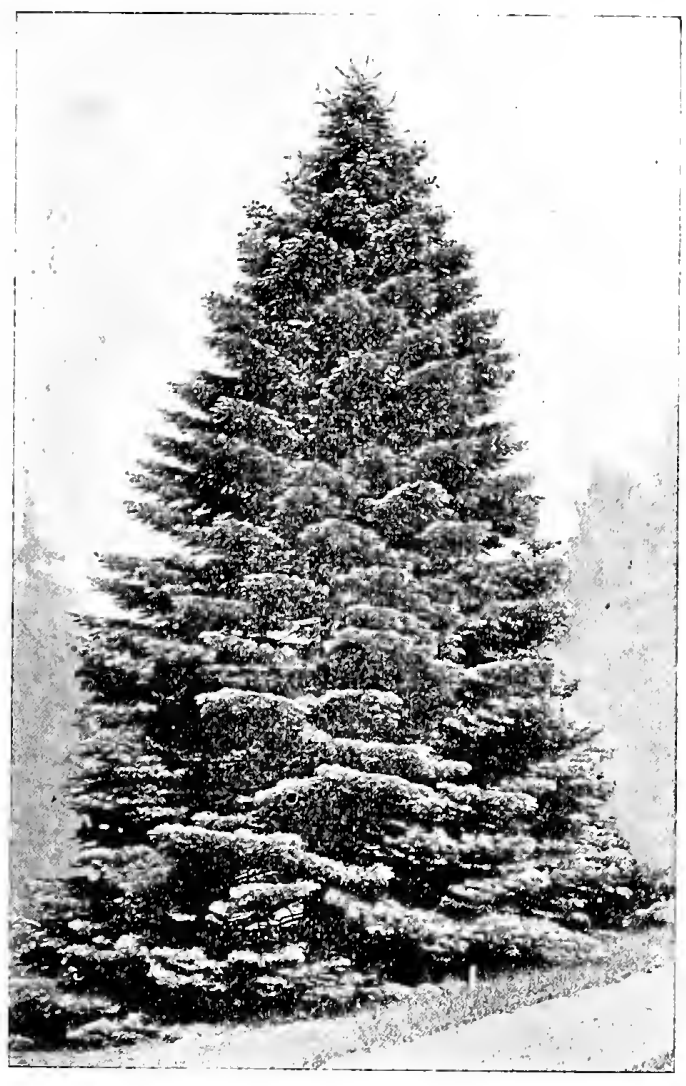

Nordman's Silver_Fir

var. Ilobosa "(Globe-headed Arborvitæ). Growing in low, thick, fglobe form I with attractive foliage.

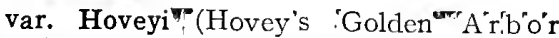
Vitae). A select American variety with bright green foliage, globe form and of 'd warf habit.

var." lutea. Bright yellow on terminal branches.

var. nyramidalis (Pyramidal Arbor Vitae). A very valuable and beautiful upright evergreen of compact habit which is in form of a column similar to Irish Juniper or erect Yew.

var. Siberica (Siberian Arbor Vitae). Exceedingly hardy, keeping color well in winter; growth compact; an elegant lawn tree; of great value for ornament and hedges. The very best.

var. Vervaeneana. A fine, hardy variety in which the green is singularly intermixed with a predominating shade of golden yellow.

orientalis semper aurescens (Ever Golden Arbor Vitae). Of dwarf habit but free growth. It retains its golden tint the year round. One of the best golden variegated evergreens. 


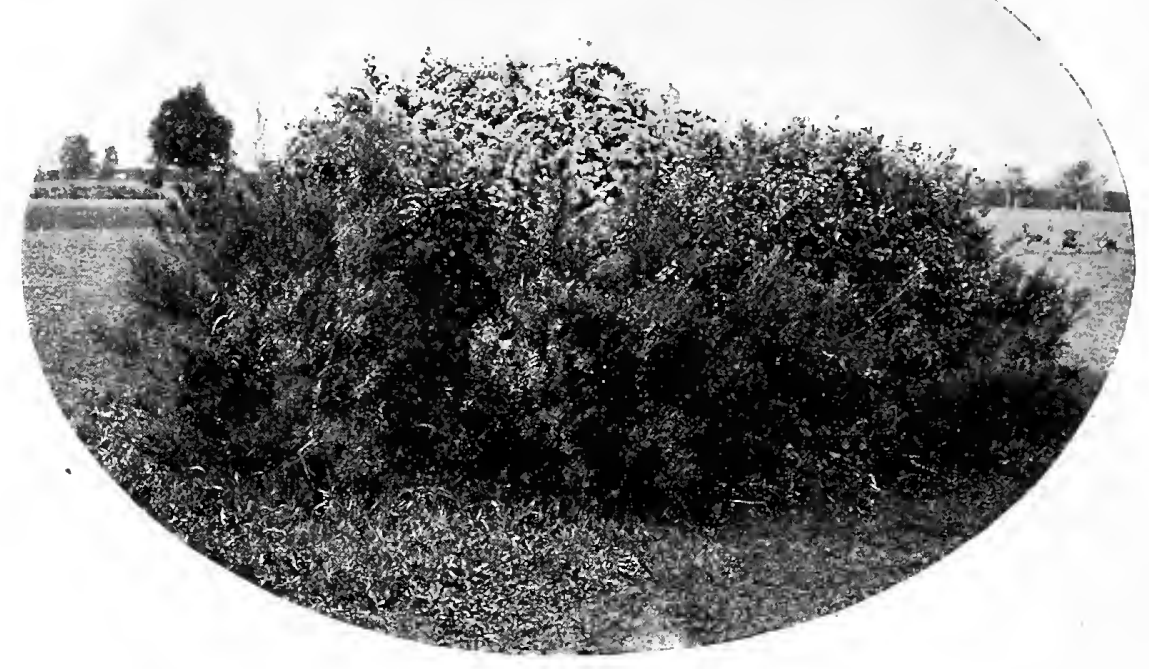

A BED OF SPIREAS ON OUR GROUNDS.

\section{DECIDUOUS SHRUBS}

Shrubs with Variegated or Colored Foliage. Althæa Variegated, Filbert, Barberry, Corehorus, Dogwood, Elder Golden and Variegated, Prunus Pissardi, Syringa Golden, Weigelia, Spirea.

Shrubs that Flower in May. Almond, Forsythia, Honeysuckle, Japan Quinee, Lilac, Exoehordia, Prunus Triloba, Snowball, Spirea, Tree Pæonia.

In June. Akebia, Clematis, Deutzia, Dogwood, Elæagnus Longipes, Honeysuekle, Lilac, Pæonia Herbaeeous, Rhododendron, Snowball, Spirea, Syringa, Weigelia, Wistaria.

In July. Clethra, Clematis, Spiræa, Honeysuekle, Elder.

In August and September. Althæa, Bignonia, Clematis, Honeysuckle, Hydrangea Panieulata Grandiflora.

Shrubs whose Flowers are Succeeded by Ornamental Fruit. Barberry, searlet berries in September; Chinese Matrimony Vine, red berries; Dogwood (Red-Branehed), white berries in September; Dogwood (Cornelian Cherry), red berries in August; Elder, purple fruit in August; Elæagnus Longipes, deep orange red berries, very showy; Highbush Cranberry; Strawberry Tree, red fruit; Mahonia, bluish berries in July; Rosa Rugosa.

\section{Amygdalus. Almond}

A. flore pleno alba (Dwarf Double Rose Flowering Almond). A beautiful shrub with small double white blossoms.

flore pleno rubra (Dwarf Double Rose Flowering Almond). These are extremcly beautiful shrubs like above with rosy blossoms.

\section{Amelanchier. Mespilus}

A. Canadensis (Common Shad Bush). Tree upright, narrow, oblong, round-topped; trunk tall and straight; branehes small and spreading; in early summer produees white, eherry-like blossoms; small purplish fruit, sweet and edible.

\section{Amorpha}

A. fruticosa (False Indigo). Long pendulous branehes, the indigo-eolored flowers in finger-like spikes. Valuable for massing. Good on poor soil.

\section{Azalia}

A. mollis. A splendid hardy speeies from Japan. One of the most valuable flowering shrubs. Flowers large and showy, like those of the Rhododendron, in fine trusses and of various eolors.

Pontica (Ghent Varieties). This class of Azaleas are sufficiently hardy for open air eulture and will stand our winters without protection, though a mulehing of straw or loose litter is desirable, at least until they beeome established.

\section{Berberis. Barberry}

B. vulgaris (European Barberry). A handsome deeiduous shrub, with yellow flowers in terminal drooping raeemes in May or June, followed with searlet fruit.

var. purpurea (Purple Leaved Barberry). Valuable for its rich, dark purple foliage, and searlet fruit.

Thunbergii (Japanese Barberry). Habit dwarf and spreading. Blooms in May are white, and berries scarlet, and in profusion. The very best hardy ornamental hedge plant we have. Autumn foliage brilliant eopper red.

\section{Benzoin}

B. odoriferum (Spice Bush). Attraetive on aeeount of its handsome foliage whieh turns yellow in the fall and for its red berries. Bark is aromatic.

\section{Cornus. Dogwood}

Alternifolia (Alternate-Leaved Dogwood). Flowers ereamy white in large bunehes, very fragrant; followed by blue berries in fall. Foliage large; distinct and curious in its habit of growth.

alba (White). Bright blood-red branches mostly with glaueous bloom when young. Flowers white early in June. mascula (Cornelian Cherry). A small tree, a native of Europe, produeing elusters of bright yellow flowers in early spring before the leaves.

var.variegata (Maseula Variegated). A variety of the above, foliage variegated with silver, low spreading branehes with clusters of white flowers in June. 
paniculata (Panicled Dogwood). Smooth ash colored bark; pointed leaves, light green above, whitish beneath. Flowers greenish white; fruit white.

Siberica (Red Siberian Dogwood). A rare and remarkable variety with bright red bark in winter.

var. variegata (Siberica Variegated). Silver margined leaves; very much like Elegans but leaves are larger and without the red tint.

stolonifera. See alba.

Spaethii. One of the finest of recently introduced shrubs. Variegated with deep yellow, and most distinct and valuable in all planting.

sanguinea (Red Osier Dogwood). Very conspicuous and ornamental in winter when the bark is red.

var. elegantissima variegata (Elegans Variegated Leaved). A new and remarkable variety with dark green foliage, margined with silver and red; wood very dark retaining its color the entire winter.

\section{Caryopteris. Blue Spirea}

C. mastacanthus. A beautiful Chinese shrub, about three or four feet high. The flowers are a rich shade of lavender or pale blue; very pretty and desirable.

\section{Calycanthus. Sweet Scented Shrub}

C. floridus. One of the most desirable shrubs; flowers in June and at intervals afterwards, having a rare and peculiar fragrance of wood and flowers; its blooms are abundant and chocolate color.

\section{Caragana}

C. arborescens (Siberian Pea Tree). A shrub or low tree. Native of Siberia and China. Pea-shaped, yellow flowers in May.

\section{Ceanothus. New Jersey Tea}

C. American. A low growing shrub; flowers white in June. Valuable for shady places.

\section{Colutea. Bladder Senna}

C. arborescens. Native of the south of Europe, A large shrub with small, delicate foliage, and ycllow, peashaped-blossom; flowers in June, followed by reddish pods or bladders.

\section{Corchorus. Kerria}

C. Japonica. This fine shrub is of a spreading habit, with slender green branches and globular yellow flowcrs.

var. flore pleno (Doublc-Flowered Corchorus). Of medium size; double yellow flowers.

var. variegata (Variegated Kerria). This variety makes dwarf twiggy growth; has white and green, variegated leaves, and bears single, pale yellow flowers.

\section{Corylus. Filbert}

\section{C. avellana (English Filbert). See Nuts.}

var. atropurpurea (Purple-Leaved Filbert). A very conspicuous shrub, with large, dark purple leaves; distinct and fine. Color good all the season.

\section{Deutzia}

D. crenata flore pleno rosea (Pink Flowering Deutzia). Flowers double, tinged with rose.

var. flore pleno alba (Candida or White Flowering

Deutzia). Flowers double; pure silvery white.

var. Pride of Rochester. One of the finest varieties, producing large, double white flowers; the back of the petals slightly tinted with rose. Blooms early in June.

gracilis (Slender Branched Deutzia). A charming species, introduced from Japan. Flowers pure whitc; fine for pot culture. Very dwarf and slender growth. An excellent forcing plant.

var. rosea (Slender Pink Deutzia). D. Of hybrid origin, closely resembling the Slender Deutzia. Light rosecolorcd flowers in profuse clusters. A pleasing variety.

var. aurea (New Golden Leaved Detıtzia Gracilis). A very beautiful low growing and bushy golden leaved shrub.

\section{Clethra. Sweet Pepper Bush \\ C. alnifolia.} Growth low and dense, leaves abundant and light green; numerous small spikes of white and very fragrant flowers in July a valuable shrub.

\section{Chionanthus. White Fringe}

C. Virginica. A na tive tree or shrub, foliage light green, flowers in racemes, very delicate white. One of the best hardy shrubs for the lawn.

\section{Cotoneaster}

C. Simonsii. A medium sized shrub flowers white, slightly pinkish fruit bright red. A native of the $\mathrm{H}$ i mal a y a s. Blooms in July.

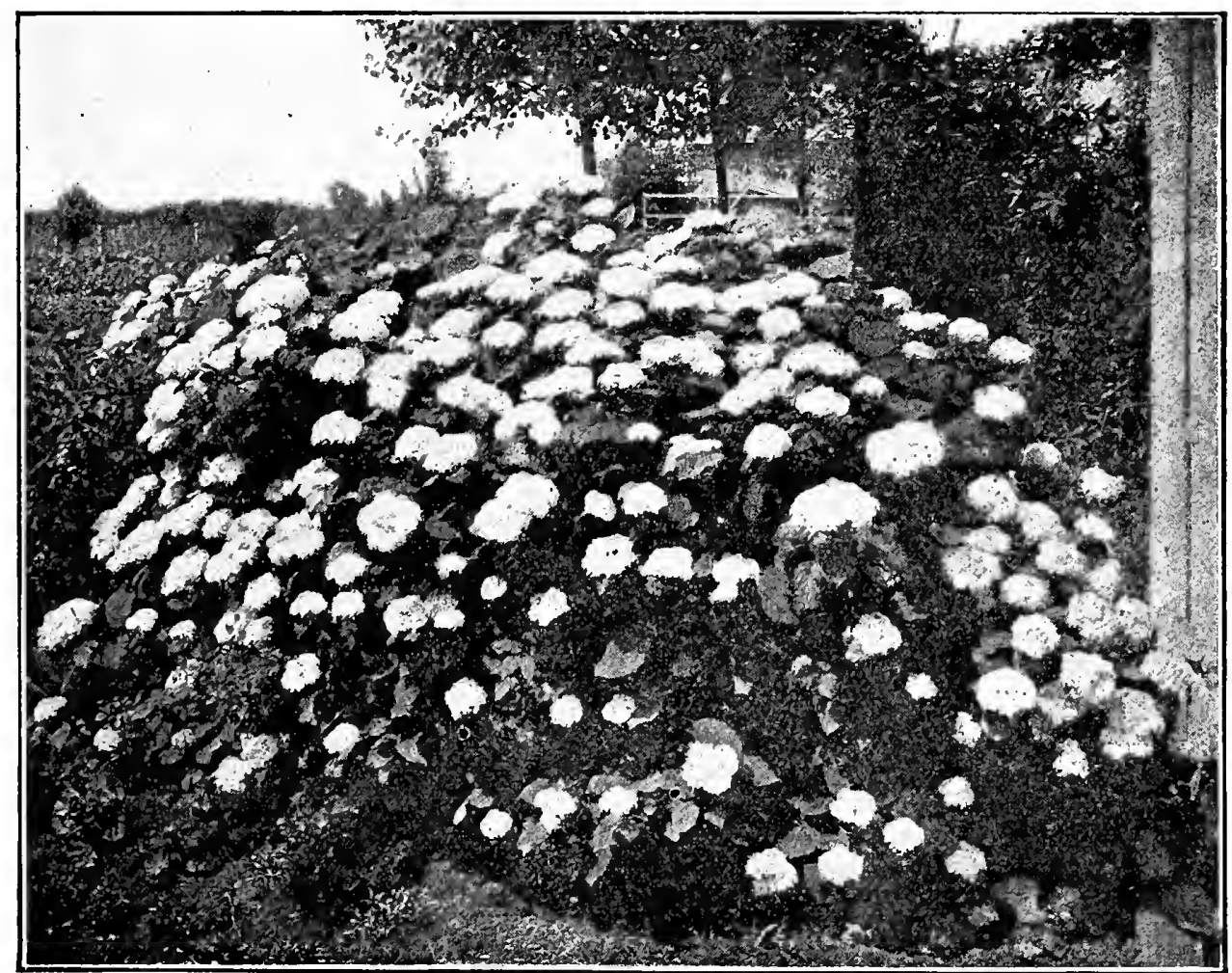

EVERBLOOMING HYDRANGEA 35 
hybrida Lemoinei. New. A remarkably fine hybrid between gracilis and parviflora. The branches are entirely covered with erect panicles of large snow-white flowers, much superior to gracilis and quite distinct from all other Deutzias.

\section{Diervilla. Weigelia}

D. alba. One of the finest plants in the spring, very hardy and a rapid grower; flowers white.

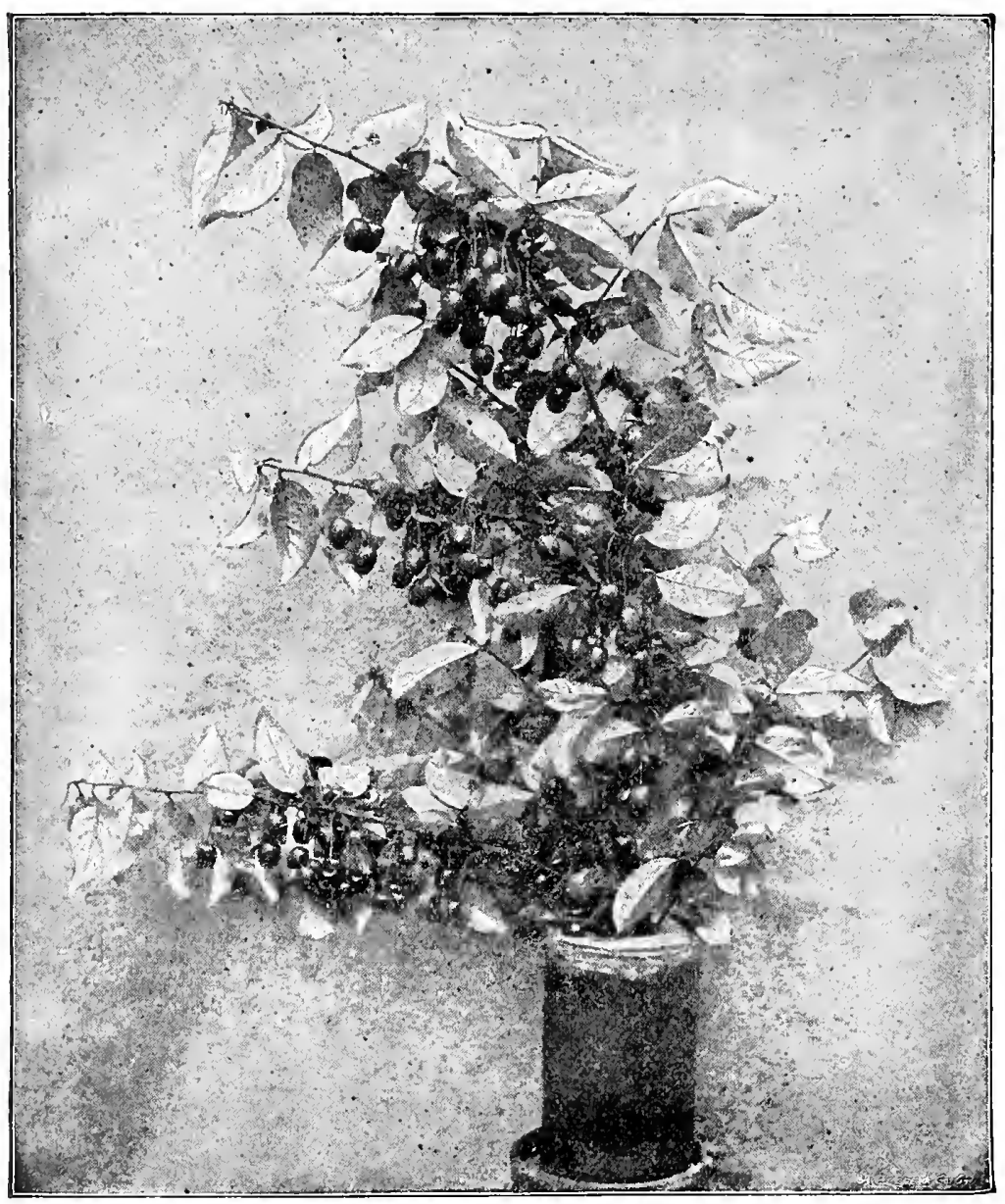

ELEAGNUS LONGIPES

amabalis. A pink-flowered variety and one of the best. Candida. It is of vigorous habit, an erect grower becoming in time a large sized shrub; flower pure white and produced in great profusion in June and the plants continue to bloom during the summer.

Eva Rathke. A popular new kind, of erect form and vigorous habit. The deèp carmine red flowers are the best of the red-flowering sorts.

Desboisii. A deep rose colored or red variety, similar in growth to Weigela Rosea, but darker.

Floribunda. Of erect habit. Dark reddish purple. One of the best. A compact, slender grower.

Hortensis rubra, syn. japonica. Abundant light crimson flowers.

rosea. A beautiful and hardy shrub, with rose-colored flowers rich in profusion, introduced from China; very hardy; blooms in June.

Nana variegata. A conspicuous variety, with foliage finely marked with yellow and green; very ornamental. Of dwarf habit; flowers very light pink.

Seiboldii variegata. Very much like the above except that the variegation is not so yellow and the plant is somewhat more erect in growth.

Van Houttei. Clear carmine flowcrs, profuse bloomer.

\section{Exochorda. Pearl Bush}

E. grandiflora. A vigorous growing shrub from China forming a compact bush 10 to 12 feet high. The flowers are borne in slender racemes of 8 to 10 florets each, on light and wiry branches. It is perfectly hardy; flowers pure white.

\section{Eleagnus}

E. longipes (Japanese Silver Thorn). A remarkable new shrub from Japan. Foliage glossy, silvery tinge underneath, bark covered with peculiar brown spots which remain all winter. Flowers not large, but the bush is covered in July with large, bright red berries, which are edible and of a sprightly and agreeable flavor.

angustifolia (Russian Olive or Oleaster). Conspicuous for the silvery hue of the foliage.

\section{Euonymus. Strawberry Tree}

See also under Vines

E. Americanus (American Burning Bush). A tall growing shrub with larger leaves than the European, turning to scarlet in autumn; fruit large, dark red.

alatus (Cork Barked Euonymous). Of dwarf, compact habit; wood very corky; leaves small. Very beautiful in autumn when foliage turns bright red.

Europaeus (European Burning Bush). Forms a tree sometimes 30 feet in height. Fruit rose-colored.

\section{Forsythia}

F. fortuneii. Growth upright, foliage deep green, flowers bright yellow. One of the best EARLY flowering shrubs, the flowers appearing before the leaves. Very hardy.

intermedia. Flowers bright golden; foliage glossy green like viridissima but hardier.

suspensa (Weeping Forsythia), Resembles the Fortunei in its flowers, but the plant has a drooping habit.

viridissima. A fine shrub, with bright yellow flowers, very early in spring.

\section{Hamamelis. Witch Hazel}

Hamamelis Virginica. Large foliage, with downy surface and showy yellow flowers, appearing after the ripening of the leaves in November.

\section{Hydrangea}

H. Otaska. From Japan. Corymbs of flowers of very large size, deep rose color; foliage larger than other varieties of the species. Growth vigorous, very attractive. Needs protection in winter.

paniculata grandiflora. One of the most valuable hardy shrubs. It attains a height of 5 to 6 feet, and is perfectly hardy everywhere. The flowers are white, borne in immense pyramidal panicles, nearly a foot in length.

Thomas Hogg. Flowers are the purest white, and are produced from July to September. A most showy shrub and especially valuable for decorative purposes; requires protection in winter.

New Everblooming Hydrangea (Arborescens var. Sterilis). One of the best shrubs ever introduced. It is easily grown, perfectly hardy, the blooms are white and 


\section{Hypericum. St. John's Wort}

$\mathrm{H}$. aureum (Golden Hypericum). One of the finest of medium growing shrubs forming a dense globular head, and producing a constant succession of golden-yellow flowers.

kalmianum. A very pretty native shrub, with rich green foliage and bright yellow blossoms. Much used in andscape planting.

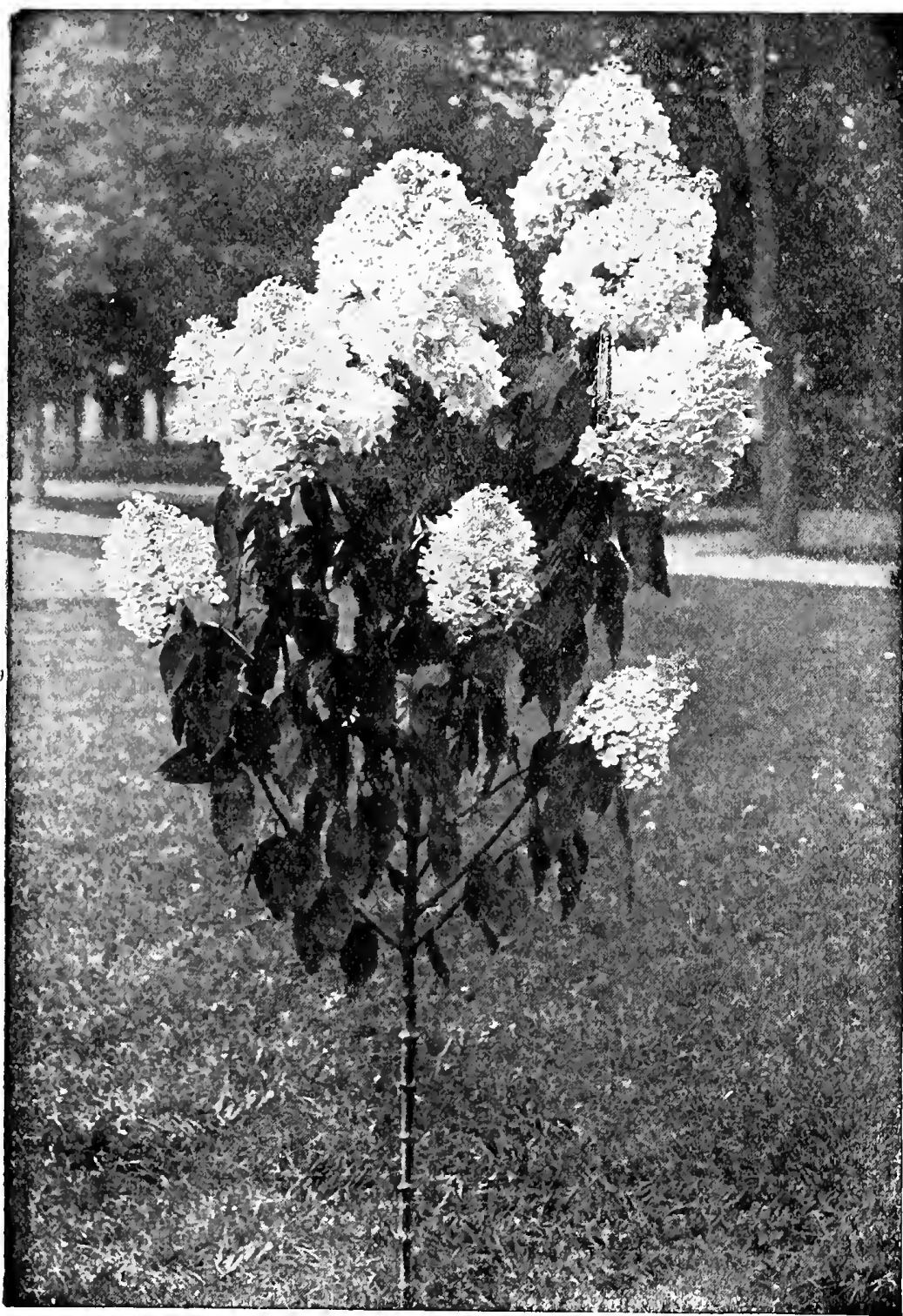

HYDRANGEA PANICULATA GRANDIFLORA-Tree form. a strong grower.

with light yellow, double purple flowers. One of the finest variegated-leaved shrubs.

var. Jeanne d'Arc. Flowers pure white, double; plant

var. Leopoldii flore pleno. Large flowers, very double, flesh color, shaded rose.

var. purpurea flore pleno (Double Purple Althaea).

var. rubra pleno (Double Red Althaea).

var. totus albus. Single, pure white; dwarf growcr.

var. variegatis flore $\mathrm{pl}$ le no (Double Variegated, or Painted Lady Althaea). White, with purple outside; petals shaded pink.

var. violacea flore pleno. Flowers medium size, double, of violet lilac color, free flowering.

Admiral Dewey. Very double, pure white flowers.

Albus oculatus. Large flower, distinct lake-red eye.

Crested Beauty. Pure white, rich velvety crimson center; very free flowering.

Puniceus roseus. D e ep rose color; large flowers.

Rubis. Single, ruby-red; fine.

\title{
Lonicera. Honeysuckle
}

\author{
See also under Vines
}

L. Alberti or Hispida (Siberian Honeysuckle). Leaves very narrow, two inches long; bluish color, on very slender, drooping branches. A little round, pendulous bush but the blossoms are the wonderful part, they are thickly set on the branches, much larger than the common sorts, and of a porcelain-blue color.

Atrosanguinea. Very large red berries, dark green, heavy foliage. A strong, vigorous grower.

Fragrantissima. A spreading shrub with deep green foliage and very fragrant, small flowers which appear before the leaves; foliage almost evergreen.

Morrowii (Morrow's Honeysucklc). * A vigorous broad spreading shrub bearing numerous yellow flowers, followed by showy crimson fruit which remains on the plant a long time and gives a very choice effect.

Tartarica rubra (Red Tartarian Honeysuckle). A well known sort. Blooms in May. Bright red flowers and followed with showy fruit.

Var. rosea (Pink Tartarian Honeysuckle). A beautiful shrub, producing large, bright pink flowers striped with white, in June.

Var. alba (White Tartarian Honeysuckle). Forms an upright bush

\section{Hippophae. Sea Buckthorn}

H. rhamnoides. Silvery gray foliage which makes it useful in landscape effects; also valued for its clusters of bright red berries.

\section{Halesia. Silver Bell}

H. tetraptera. A small native tree, bearing most beautiful bell-shaped flowers, similar to the Snowdrop but much larger. Blooms in May.

\section{Hibiscus. Althea or Rose of Sharon}

H. Syriacus var. flore pleno fol. var. (Variegated-Leaved Double Purple-Flowered Althea). Foliage finely marked with white flowers and followed with yellow fruit.

Ruprechtiana. A fine variety from Manchuria. Particularly valuable for its showy red fruit. Foliage dark red above and grayish beneath.

Bella albida. White flowers, showy red fruit in great profusion.

\section{Philadelphus. Mock Orange or Syringa}

P. argentea (Boule'd Argent). Double flowers with a beautiful silvery tinge, dwarf habit.

aurea (Golden Syringa). A new gold leaf shrub of delicate growth and beauty. It is sufficiently free to make it very valuable for clumps and hedges. 
grandiflora (Large Flowering Syringa). Habit strong $F$ with large white flowers.

Coronarius (Syringa Garland). A very fine shrub, with wonderful sprays of sweet scented flowers.

flore pleno (Double Flowering Syringa). Habit strong, dwarf growing, with semi-double white flowers.

Lemoineii erectus (Lemoine's Erect Syringa). A charming variety of upright growth; flowers small, yellowish white, fragrant, completely covering the plant.

\section{Prunus. Plum}

P. triloba (Double Flowering Plum). A very hardy and beautiful tree form shrub covered in early spring with a profusion of double pink flowers an inch in diametcr.

Pissardi (Purple Leaved Plum). A beautiful purple leaved shrub of recent introduction. The branches arc very dark purple, the leaves when first formed are rich crimson, changing to dark purple, and retain this beautiful color, until they drop, late in autumn.

\section{Pyrus Japonica: Japan Quince}

P. Japonica rubra (Scarlet Japan Quince). Especially well adapted for hedges and ornamental shrubbery. Its beautiful red flowers and rich green foliage make a very charming landscape.

var. alba (White Japan Quince). Flowers slightly tinged with pink. A very beautiful shrub but not so showy as the former.

\section{Ptelia. Hop Tree}

P. trifoliata (Green Leaved Hop Tree). A large shrub or small tree, of rapid growth and robust habit. Fruit winged and in clusters; flowers in June.

Var. aurea (Golden Hop Tree). Bright golden foliage, which unlike most other yellow-leaved shrubs, does not fade, but retains its brilliant color until frost. One plant lights up an entire group in the border.

\section{Robina. Locust}

See also under Ornamental Trees

R. hispida (Acacia or Moss Locust). A native species of spreading irregular growth, with elegant clusters of rosecolored flowers in June, and at intervals all the season.

\section{Ribes. Currant}

The flowering currants are of easy cultivation and hardy, and arc very interesting from their profuse flowering in early spring.

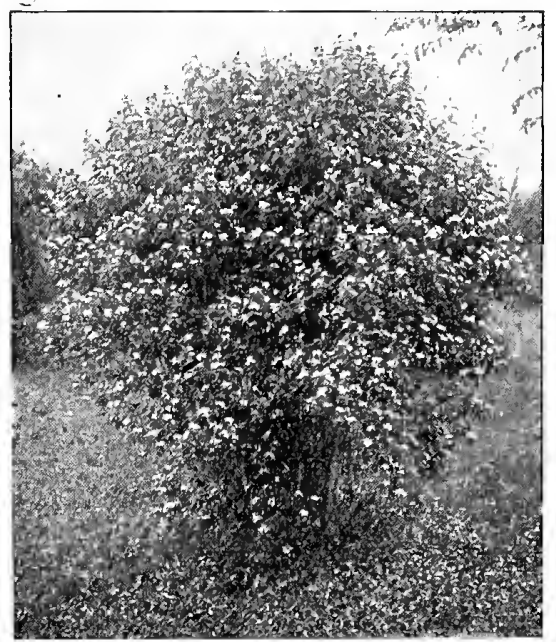

Tartarian Bush Honeysuckle

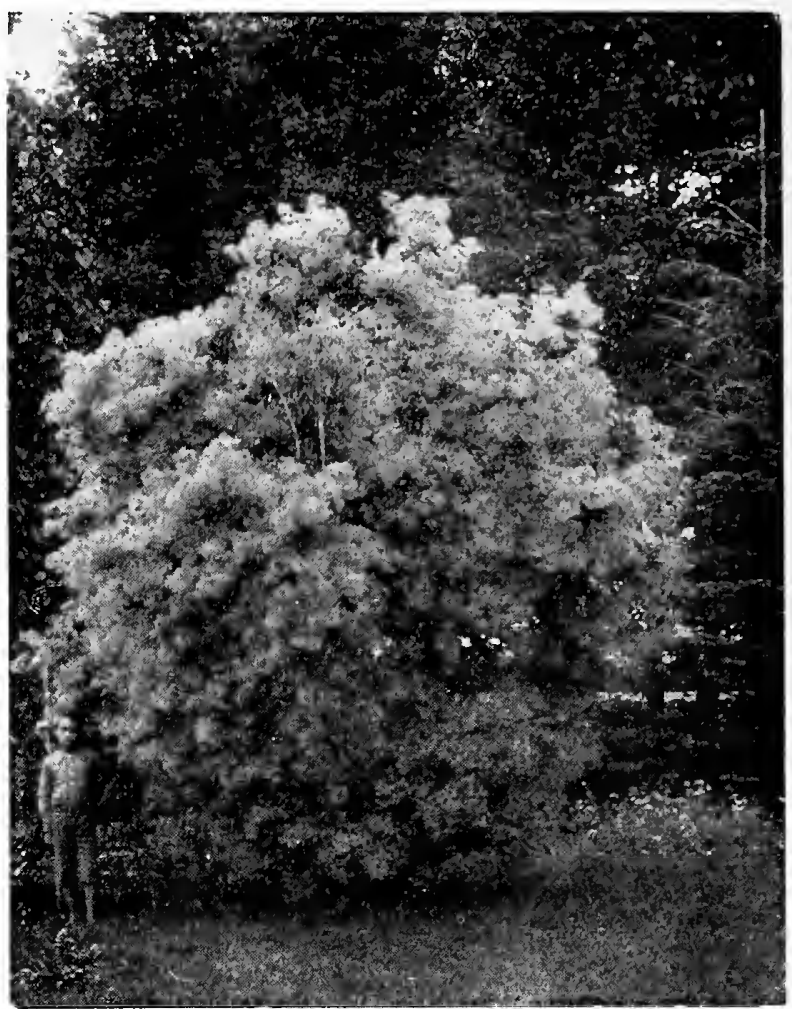

Purple Fringe

R. aureum (Yellow Flowering or Missouri Currant). A native species, with glabrous, shining leaves and yellow flowers.

Gordonianum (Gordon's Flowering Currant). A valuable and profuse flowering variety. Flowers crimson and yellow, in pendant clusters.

Sanguineum (Crimson Flowering Currant). An American species, with deep red flowers, produced in great abundance in early spring.

Crandall's. A seedling from the west; blooms profusely; bright yellow flowers; fruit of a red black color.

\section{Rosa. Bush Roses}

R. blanda. S. May. A thomless varicty. Of pale foliage, and large, bright rose-colored flowers, single. Scarce.

R. Carolina (Swamp Rose). M. June to Sep tember. The tall growing wild rose, with single pink flowers.

R. lucida. S. May to July. A fine native, with rosy pink flowers. Does well on poor soil.

R. var. alba. D. This is a valuable new sort, with pure white flowers and green stems.

R. multiflora (Japan). M. June. Its foliage is very clean and bright all summer. Its blossoms are produced in immense quantities, single, pure white, and followed by equally great numbers of small, scarlet hips all winter.

R. rubiginosa. L. The well known Sweet Briar, with highly-scented foliage, small, pink, fragrant flowers and quantities of bright hips. Blooms in June.

R. rubrifolia (Red-leaved Rose). M. August. Quite unique and conspicuous for its high-colored, reddish purple leaves, retained throughout the summer. Deep red flowers.

R. rugosa. Its stout stems are densely beset with prickles; foliage shining dark green, deeply plicated, flowers single, red, fragrant, and produced freely from June to December; fruit bright crimson-scarlet.

\section{Rubus. Raspberry}

R. odorata (Flowering Raspberry). Large foliage, pretty rose-purple flowers. 


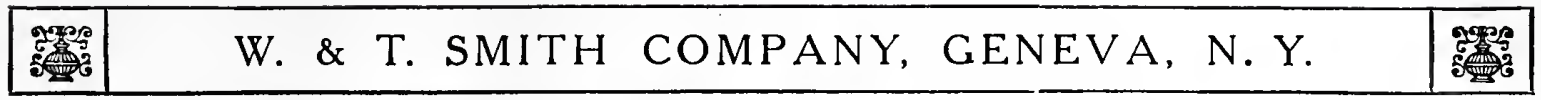

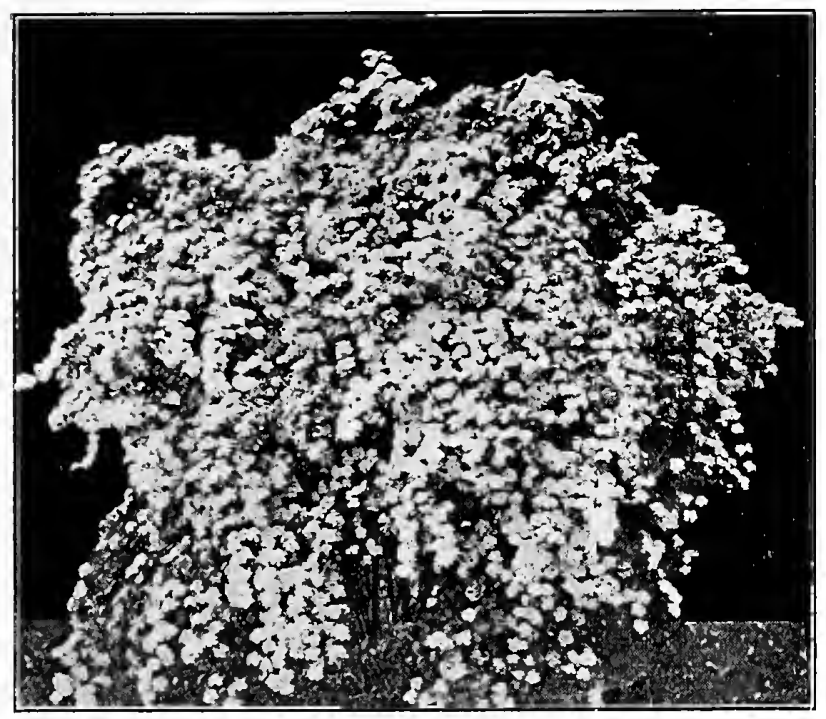

Spirea Van Houtte

sorbifolia (Strawberry Raspberry). A cross between the strawberry and raspberry. Fruit large and brilliant, fine green foliage all summer. Very ornamental for border and bedding.

\section{Rhodotypus}

R. kerriodes. A Japanese shrub of medium size, very ornamental, with handsome foliage and large, single, white flowers in the latter part of May.

\section{Rhus. Sumac}

R. aromatica (Fragrant Sumach). A native variety, exhaling a strong odor. Flowers greenish-white; leaves lobed.

copallina (Dwarf Sumach. Shining Sumach). Beautiful shining green foliage changing to rich crimson in autumn. Greenish-yellow flowers in August.

cotinus (Purple Fringe or Smoke Tree). From the south of Europe. A shrub much admired for its curious fringe, or hair-like flowers, that cover the whole surface of the plant in mid-summer.

glabra (Smooth Sumac). Very effective in autumn with its crimson seeds and foliage.

var. laciniata (Cut Leaved Sumac). A very striking plant of medium size, with deeply cut leaves, resembling fern leaves; dark green above and glaucous below, and turning to a rich red in autumn.

typhina (Staghorn Sumac). A large shrub or tree, brilliant foliage and scarlet fruit in autumn.

var. laciniata (Cut Leaved Staghorn Sumac). A very graceful shrub, with delicate fern like leaves, most brilliant in the autumn.

\section{Stephanandra}

S. flexuosa. A thick shrub with graceful branches and handsome small foliage that is almost as delicate as a fern and turns a bronze red in late summer and autumn.

\section{Sambucus. Elder}

S. Canadensis (Common Elder). Broad panicles of white flowers in July, reddish purple berries in autumn. A well known native shrub.

Nigra (Black Berried Elder). A native of Europe, of medium size, with purplish-black berries in September.

var. aurea (Golden Elder). A handsome variety, with golden yellow foliage. A valuable plant for enlivening shrubberies.

var. laciniata (Cut Leaf Elder). A valuable variety with elegantly divided leaves; one of the best cut-leaved shrubs. var. variegata (Variegated Leaf Elder). Of strong, healthy growth; foliage mottled with yellow and white. One of the best variegated leaved shrubs.

racemosa sym. pubens (Red Berried Elder). Panicles of white flowers in spring, followed by bright red berries.

\section{Spiraea. Meadow Sweet}

S. arguta. One of the finest of early spring blooming shrubs of light open habit of growth, with small deep green foliage of minute purest white flowers.

Billardi. Blooms nearly all summer; rose colored, fine, showy.

Bumalda. A variety from Japan; blooms all summer. Showy rose colored flowers. Growth dense and of dwarf habit.

var. Anthony Waterer. A new dwarf compact growing shrub. Blossoms in broad flat heads of beautiful deep red color. A perpetual bloomer.

Callosa. Red flowering spirea of dwarf habit, very fine and hardy.

var. alba. A white flowering Spiraea of dwarf habit very fine and hardy; blooms in July, August and September.

Douglassi. A native shrub very hardy with panicles beautiful deep pink.

grandiflora (Large Flowering Spirea). Has very large, cream colored flowers; very showy. A strong grower.

lanceolata (Reevesii). A charming shrub, with round heads of white flowers and narrow pointed leaves. Blossoms in May.

opulifolia. A very strong growing shrub. Valuable for massing. White flowers in June.

var. aurea (Golden Spirea). An interesting variety, with golden yellow foliage, and tinted flowers in June. Very conspicuous. Strong grower and distinct.

prunifolia (Bridal Wreath). Beautiful white flowers double and very profuse. Blooms in May. Foliage scarlet in autumn. (See cut).

sorbifolia. A vigorous species with leaves like the Mountain Ash, and long elegant spikes of white flowers.

tomentosum (Steeplebush). Valuable because it blooms late and very decorative with its showy panicles.

Thunbergii. A Japanese species of small size, with narrow delicate leaves and small white flowers; one of the best.

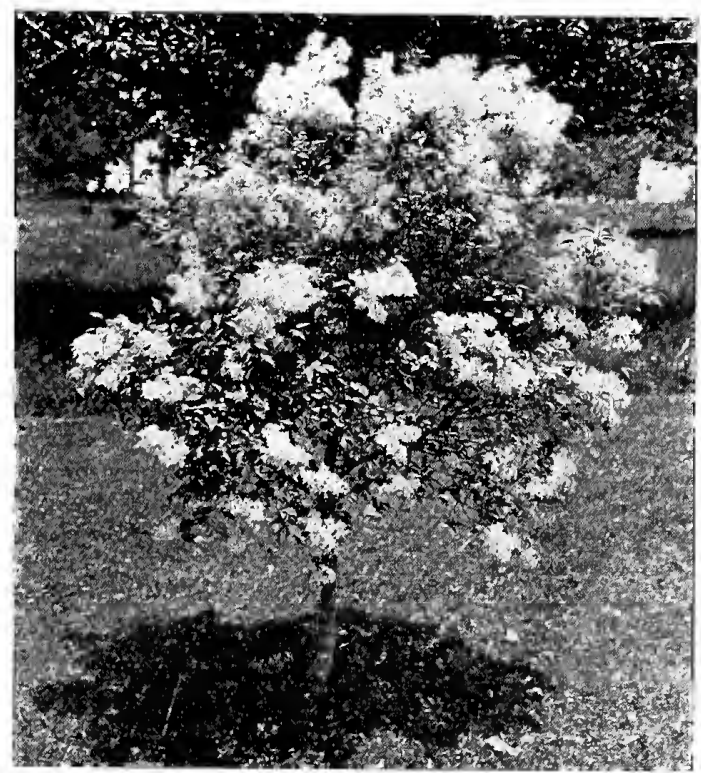

White Lilac Tree 
ulmifolia (Elm Leaved Spirea). July. Elm like leaves, and large clusters of white flowers.

filipendula (Dropwort). (Herbaceous). Foliage dense, dark green and beautifully cut. Blooms in showy heads of white flowers.

Van Houttei. The finest of all Spiraeas, a most charming and graceful shrub having pure white flowers in clusters. Extraordinary profuse in bloom, and plant is a vigorous grower and very hardy.

\section{Syringa. Lilac}

S. Chinensis alba (Chinese White Lilac). Growth similar to Persian, but blooms nearer white.

Japonica (Giant Japan Tree Lilac). A species from Japan. Leaves thick, pointed, leathery and dark; flowers in very large panicles, creamy white and privet like.

Josikaea. Thick shining leaves and clusters of purple flowers; much later than common Lilacs. Very desirable.

Persica (Persian Purple Lilac). Native of Persia. Leaves small dark green; flowers abundant, delicate and purple.

var. alba (Persian White Lilac). Same habit of growth as foregoing. Blossoms in long panicles, white tinged with purple.

Rubra de Marley. A very free bloomer; flowers reddish purple; one of the best varieties for winter forcing.

Rothamagensis (Rouen or Red Lilac). A distinct hy brid variety with reddish flowers; panicles of great size and very abundant.

Villosa. A new Japanese variety; flowers large, light purple in bud, white when open; fragrant; very late bloomer and most desirable.

vulgaris (Common Purple Lilac). Blossoms early, reddish purple.

var. alba (Common White Lilac). Blossoms early, pure white and very fragrant.

var. Charles $\mathrm{X}$. A strong growing sort; large, loose clusters of purple flowers; an improved variety of the vulgaris.

Alphonse Lavallee. Trusses like a double Hyacinth, fine, blue, shaded to violet.

Belle de Nancy. Large, double pink with white center.

var. Dr. Breitschneider. A very beautiful lilac, especially worthy of cultivation. Much like Lamarck but darker.

var. Emile Lemoine. Very fine, double pink.

var. Frau Dammann. Immense panicles of white flowers of very large size. Best white variety.

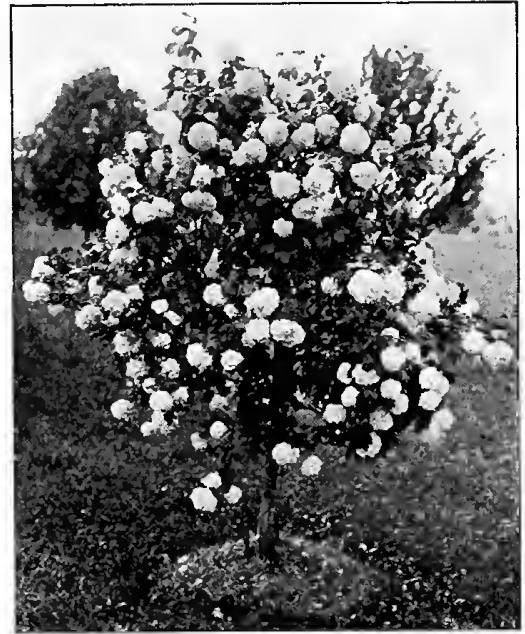

Common Snowball.

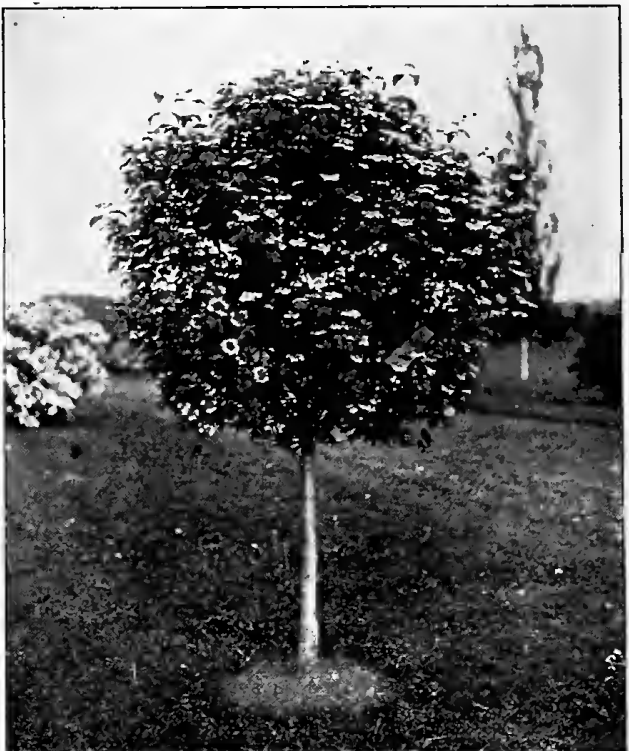

High Bush Cranberry Tree.

var. Jean Bart. Rosy carmine flowers in large, compact plumes.

var. La Marck. Very large panicle; individual flowers, very double, rosy lilac.

var. Ludwig Spaeth. Panicle long; individual flowers large. Single; dark purplish red. The finest of its color.

var. Mad. Casimir Perier. Large trusses of very double, creamy white flowers. One of the very best.

var. Marie Le Graye. Large panicles of pure white flowers. A valuable variety for forcing.

var. Michael Buchner. Plant dwarf; panicle erect and very large; very double, color pale lilac; distinct and fine.

var. Mad. Lemoine. A grand double white variety. Vigorous habit and immense foliage.

var. Mathieu de Bombasle. A handsome double blue flower and large truss.

var. President Grevy. A new variety; strong grower; blossoms in very large clusters of semi-double bluish flowers; one of the best.

var. Virginite. Flowers large, double, rose, shade of La France Rose.

var. grandiflora. Very large, pure white trusses of flowers.

\section{Symphoricarpus. Snowberry}

S. vulgaris (Red Fruited Snowberry or Indian Currant). A shrub of very pretty habit. Foliage, flowers and fruit small purple and hangs all winter.

var. variegata (Variegated Leaved). Variegated form of the above.

racemosus (White Snowberry). A well known shrub with small pink flowers, large white berries that hang on the plant through part of the winter.

\section{Tamarix}

T. Africa. Foliage very fine and feathery on slim branches, flowers pink, very small and very numerous so as to cover the branches of preceding year's growth.

Gallica. July. Very showy in bloom. Pink blossoms; later than the African.

Germanica. Foliage bluish green, flowers pink; a native of North China and Japan.

Indica. Beautiful deep green foliage with plume-like pink flowers in September. 


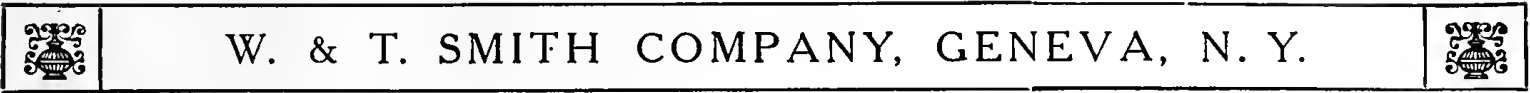

\section{Viburnum. Arrow Wood}

V. dentatum. June. Glossy, handsome leaves, white flowers and fine steel-blue berries in fall.

V. Opulus (Highbush Cranberry). Foliage yellowishgreen, large, whitish blooms in June. In the fall covered with large, red berries.

V. cassinoides. M. June. Flat heads of white flowers, and effective foliage. Bears black berries in clusters.

V. Lentago (Sheepberry). M. Flowers creamy white, very fragrant; foliage a light, glossy green.

V. molle (Soft leaved Viburnum). M. A native, but very rare. It resembles $\mathrm{V}$. dentatum, but has broader foliage and larger fruit.

V. Sieboldi. Large, long thick leaves of a glossy green color; very showy.
V. plicatum (Japan Snowball). Handsome plicated leaves; globular heads of pure white neutral flowers, early in June. It surpasses the common variety in several respects, its habit is better, foliage much handsomer, flowers whiter and more delicate.

V. tomentosum (Single Flowered Japan Snowball) Flowers pure white, borne along the branch in flat cymes, in the greatest profusion, early in June. Perfectly hardy, vigorous, and free blooming.

V. lantana (Lantana Leaved). A large shrub with soft heavy leaves and large clusters of white flowers, succeeded by red fruit; retains its foliage late.

\section{Xanthoceras}

X. sorbifolia. A large growing sbrub or small tree from China, foliage similar to Mountain Ash. The flowers are about the size of Horsechestnut blossoms and white with a pink eye, borne in long spikes in great abundance.

\section{CLIMBING SHRUBS OR VINES}

\section{Akebia}

A. quinata. A rapid growing climber with clover-like leaves. Flowers in clusters, purple.

\section{Ampelopsis}

A. Englemanni. Very similar to Quinquefolia, clings closely to its support, and is a valuable vine for covering walls and trellises and for running over trees and ugly places.

quinquefolia (American Ivy or Virginia Creeper). A very rapid growing vine coveied with heavy digitate leaves affording shade and of great beauty when changing to scarlet in autumn. The best climber to grow over porches, rocks or tree stumps.

Veitchii (Boston or Japan

Ivy). The now famous Japan or Boston Ivy used so extensively to cover brick or stone buildings. The foliage is dense, completely carpcting a surface and the autumnal tints of green and red are unsurpassed for beauty.

\section{Aristolochia. Dutchman's Pipe}

A. Sipho (Birthwort). A native species of climbing habit and rapid growth, with very large heart-shaped leaves and curious pipe-shaped, yellowish-brown flowers.

\section{Bignonia. Trumpet Flower}

B. radicans. A strong climber. Foliage dark green and pinnate. Flowers in clusters trumpet shape orange red, 5 to 6 inches long at intervals through the summer.

grandiflora. A variety having large dark orange colored flowers.

\section{Celastrus. Bitter Sweet}

C. scandens. A fine native climber with clusters of orange red seeds.

\section{Clematis. Virgin's Bower LARGE FLOWERING HYBRID SORTS}

C. Duchess of Edinburgh. Double, white, fragrant.

Jackmanni. Large, rich violet purple, flowers in masses and a successive bloomer.
CLEMATIS PANICULATA

Henryi. Very large, white and prolific bloomer. The best white.

Madam Edouard Andre. New, large, deep velvety crimson flowers. A fine bloomer, a great acquisition.

Sieboldii or Ramona. Large, very fine, bright blue flowers.

\section{SELECT LIST OF OLD AND NEW SORTS}

C. Coccinea (Leather Flower). A curious bell-shaped heavy petaled flower, borne in profusion for a long season, color bright scarlet.

Crispa. Form of blossom similar to above, of lilac color.

Paniculata. A new Japanese plant which has proved perfectly hardy, one of the finest climbers, vigorous, handsome foliage; produces late in summer a profusion of medium sized pure white, deliciously fragrant flowers.

\section{Dioscorea. Cinnamon Vine}

D. divaricata (Chinese Potato or Yam). Very tall climber, roots very deep. A tropical plant but hardy here.

\section{Dolichos. Pueraria. Kudzu Vine}

Dolichos Japonicus. An extremely fast-growing vine, with immense leaves, bearing small racemes of rosy purple pea-shaped flowers towards the close of August. 


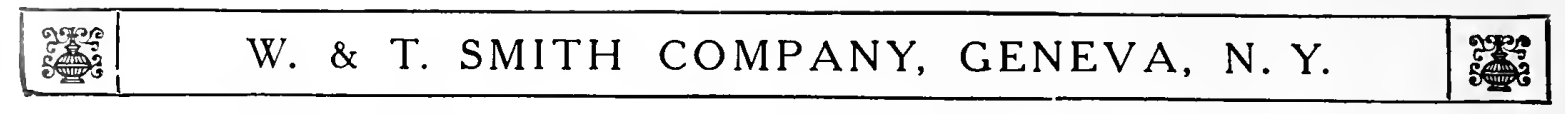

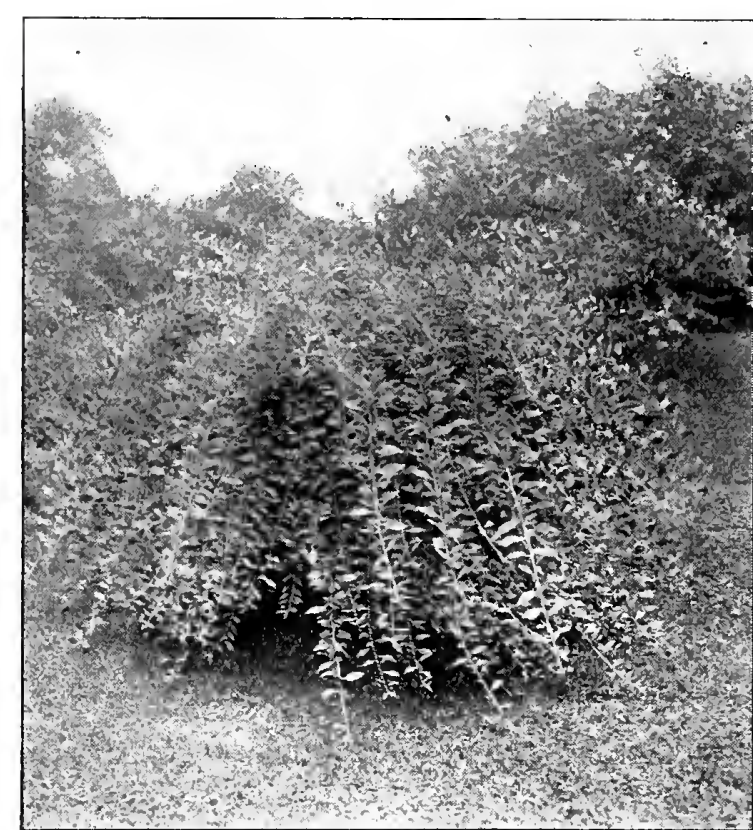

Chinese Matrimony Vine

\section{Euonymous}

E. marginata alba (Variegated Leaved Euonymous). Silver striped and edged with silver; a beautiful evergreen plant; slow grower; valuable for edging borders.

radicans. Foliage green, edged with silver; more hardy than the preceding.

\section{Lonicera. Honeysuckle}

L. aurea reticulata (Golden Leaved Honeysuckle). The most beautiful variety of this class of climbers; leaves of bright green, and golden yellow; fine for bedding, pot culture or for hanging baskets; perfectly hardy.

flava (Yellow Trumpet Honeysuckle). Very fragrant, yellow trumpet flowers.
Halleana (Hall's Japan Honeysuckle). A strong growing variety, almost evergreen, holding its foliage until late in January. The flowers are pure white and yellow, very fragrant and cover the vines from July to December.

Japonica (Chinese Twining Honeysuckle). Retains its foliage nearly all winter; is quite fragrant and a desirable variety.

Heckrotti. A new climbing variety; flowers rose color outside, yellow center. A good bloomer and strong grower.

periclymenum (Belgica, Monthly Fragrant or Dutch Honeysuckle). Sweet scented, very fine; continues in bloom all summer.

pallida. White and Straw colored fragrant flowers; shining, deep green leaves.

sempervirens (Scarlet Trumpet Honeysuckle). Strong rapid grower, scarlet fragrant trumpet flowers. Blossoms all summer.

\section{Hedera. Ivy}

H. helix (English Ivy). An old variety, a hardy climbing evergreen.

var. marginata argentea (New Silver Striped). Deep green leaves, heavily margined with white.

\section{Lycium. Matrimony Vine}

L. Sinensis (Chinese Matrimony Vine). A vigorous climber, branching freely, and covered with bright purple, star-shaped flowers, succeeded by brilliant scarlet berries almost an inch long.

\section{Wistaria}

W. magnifica (American Purple). An elegant climber with bluish purple, sweet scented flowers, and a rapid grower.

Sinensis (Chinese Purple Wistaria). A beautiful climber of very rapid growth and producing long pendulous clusters of pale blue flowers in June and also in the autumn.

var. alba (Chinese White Wistaria). Similar in form to the above, except in the color of the flowers, which in these are pure white.

\section{HEDGES}

The idea of planting hedges for use as well as for ornament, for the protection of orchards, farms and gardens, is a practical one, and rapidly becoming appreciated.

They serve as a protection against winds and prevent the blowing off of fruit. We know that our gardens are earlier, and that our fruits ripen better when protected by such screens. Nothing can be more beautiful than ornamental hedges of Evergreens, or shrubs well kept and pruned to serve as boundary lines or as divisions between the lawn and garden, or to hide unsightly places. By using medium-sized plants, a hedge can be made as cheaply as a good fence can be built, and then, with little care, it becomes every year more and more "a thing of beauty." An attraction in our best-kept places.

\section{For Ornament}

Among the plants adopted to ornamental hedges, the American Arbor Vitæ and the Norway Spruce take the first place. We also recommend for more variety, the Hemlock, Siberian Arbor Vitæ, Japan Quince, Althea, Barberry, Buckthorn, Privet, Tartarian Honeysuckle, Spiræas, Deutzia, Philadelphus, Box, and Mahonia.

\section{For Shelter and Screens}

For planting in belts to afford shelter from violent winds, or for concealing unsightly objects or views, we recommend Norway Spruce, Austrian, Scotch and White Pine, American Arbor Vitæ, to which we may add Carolina Poplar and Silver-Lcaved Maple.

\section{Directions for Setting}

Evergrcens must be handled with care, so as not to allow the roots to become dried by the wind. Plants for hedges being generally set when quite small, should be placed about nine inches apart; larger sized plants will require more space.

Buckthorn, Honey Locust and Osage orange are generally planted in double rows, about nine inches apart.

\section{Pruning}

Evergreens should be pruned in spring, just before they commence growing. Summer pruning may be practiced on the Arbor Vitæ should the growth be too rapid. 


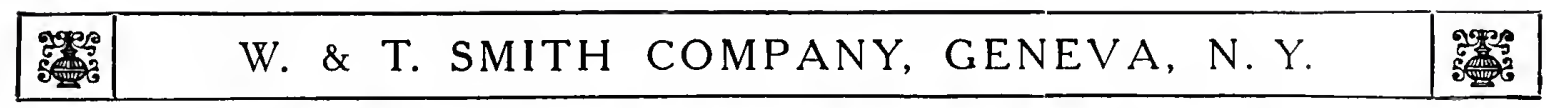

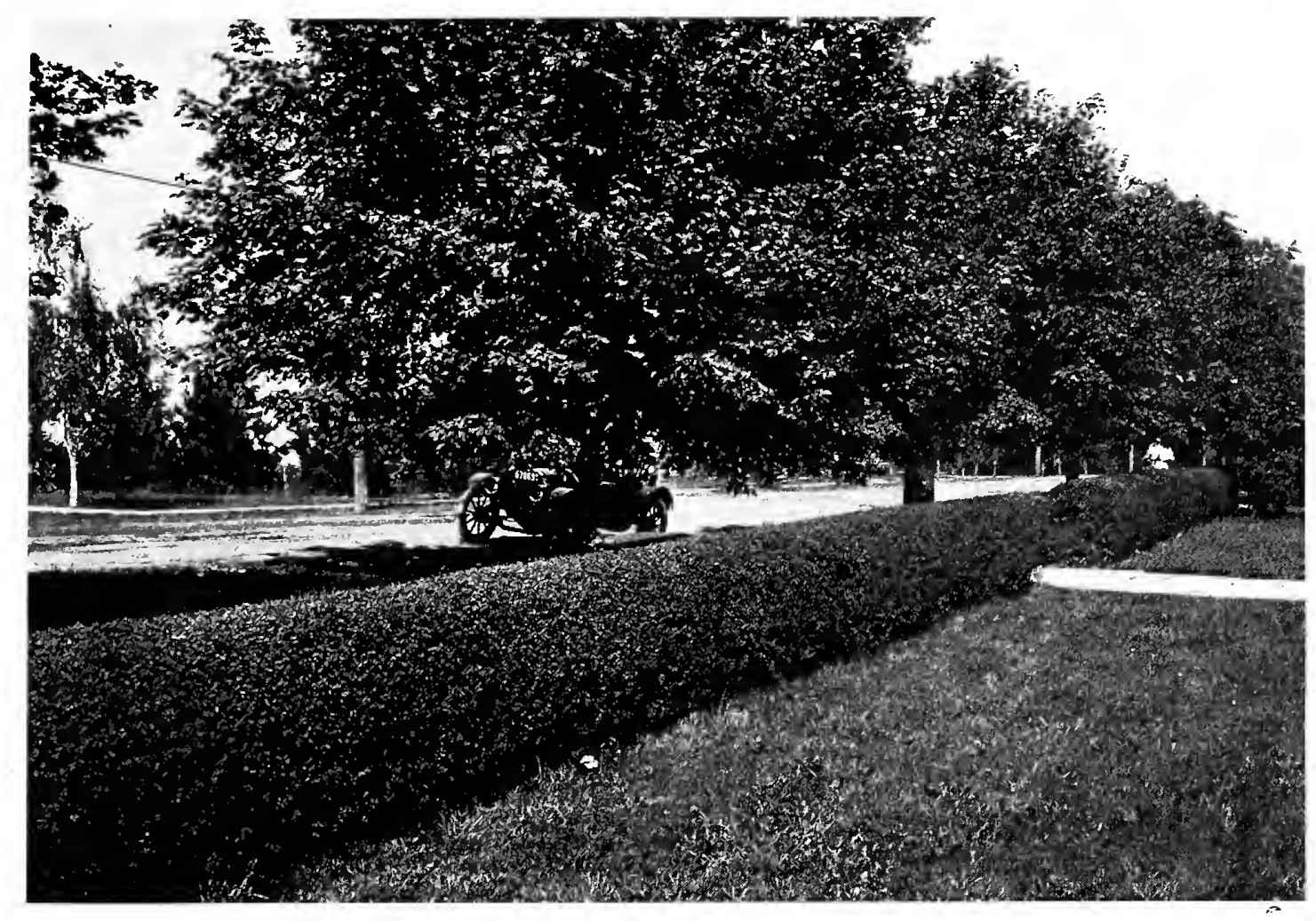

A HEDGE OF BARBERRY THUNBERGII OR JAPANESE BARBERRY

\section{Buxus. Box}

B. sempervirens (Tree Box). Very ornamental, slow growing variety, with small shining dark green foliage. One of the most useful varieties. Thrives in any well drained soil, stands all kinds of pruning, and is grown in many forms.

var. suffruticosa nana (Dwarf Box). A very slow growing variety, with small, glossy, dark green foliage. The well known form so extensively used for Box borders.

\section{Berberris. Barberry}

B. Thunbergii (Japanese Barberry). This shrub we particularly recommend to our patrons for a hedge plant. Its hardiness, bushiness and beautiful foliage promise to make it our most popular hedge. The foliage turns a beautiful copper color in the fall and brilliant fruit remain on all winter.

\section{Ligustrum. Privet}

L. Ibota (Ibota). A pretty Japanese shrub with slender twig-like branches and small lanceolate leaves. It has round, shining, black berries. Very ornamental and perfectly hardy.

var. Regelianum (Regel's Privet). Low, dense shrub with almost horizontally spreading branches and oblong leaves. Very graceful and perfectly hardy. ovalifolium (California Privet). Rapid grower with bright shining leaves. This shrub grows freely in almost any soil, is compact in form and can be trimmed to any desired shape; flowers during June and July. Desirable for hedges.

vulgaris (English Privet). Bears pretty spikes of white flowers, succeeded by bunches of black berries like surrants; makes a beautiful hardy hedge plant.

\section{DEFENSIVE HEDGES}

For turning cattle and for farm hedges in general, the following will be found very serviceable.

\section{Rhamnus. Buckthorn}

R. cartharticus. A fine, robust, hardy shrub of European origin, with dark green foliage, white flowers and small, black fruit. A popular hedge plant.

\section{Maclura. Osage Orange}

M. aurantaica. A native tree of medium size and spreading habit. Leaves bright, shining green, broad and sharp pointed. The fruit resembles an orange.

\section{Gleditschia. Honey Locust}

G. triacanthos. A rapid growing native tree, with powerful spines and delicate foliage. Very useful as a defensive hedge plant. 


\section{EVERGREEN SHRUBS}

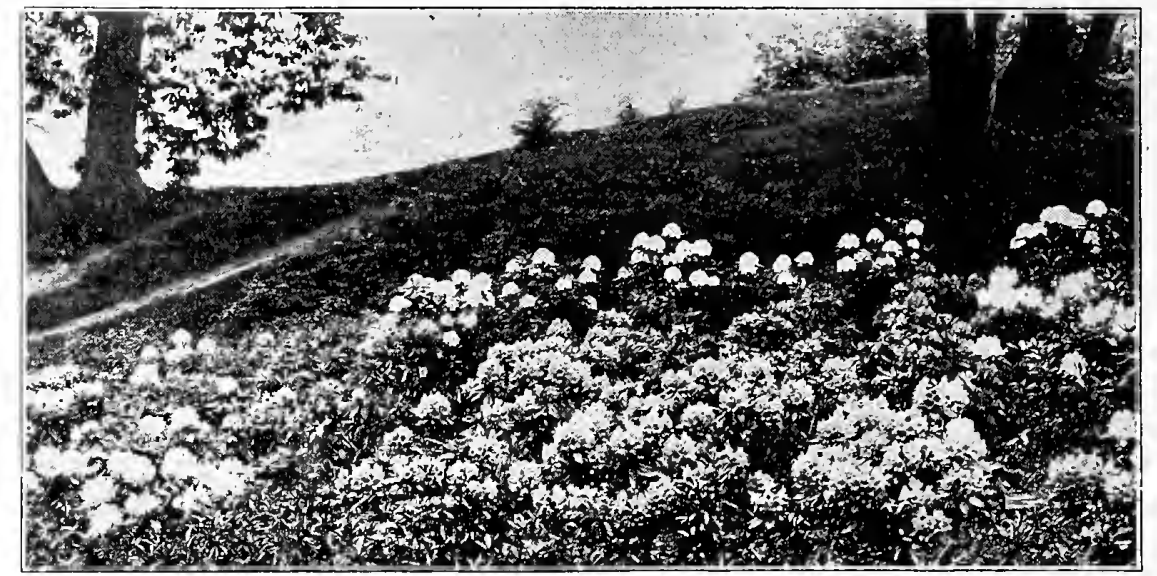

A BED OF RHODODENDRONS

\section{Andromeda}

A. floribunda. D. A very pretty, evergreen plant, of dwarf, compact habit, with rich dark green foliage and pure white flowers in great abundance in spring; requires same treatment as the Rhododendron.

\section{Buxus. Box}

The species and varieties of the Tree Box are beautiful lawn shrubs or small trees, well adapted to small places. They flourish best when partially shaded. In this climate they require protection.

B. sempervirens (Common Tree Box). From England. A handsome shrub with deep green foliage. var. nana (Dwarf Box). The well known sort used for edging.

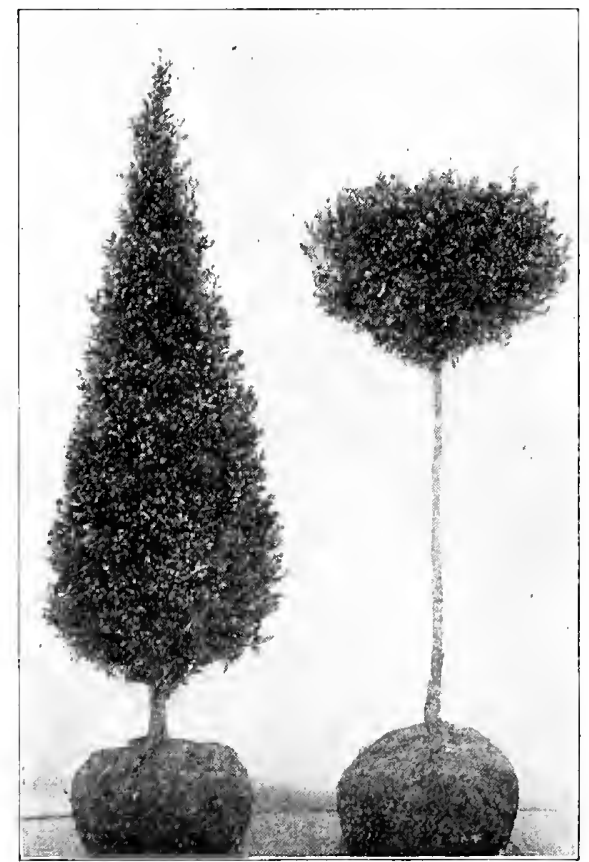

Box Trees

\section{Kalmia. American or Mountain Laurel}

K. latifolia (Calico Bush). A beautiful native evergreen shrub, with shining foliage and dense clusters of pink or nearly white flowers in spring. Requires same treatment as the Rhododendron.

\section{Mahonia. Ashberry}

M. aquifolia (Holly Leaved Mahonia). A native species of medium size, with purplish, shining, prickly leaves, and showy, bright yellow flowers in May, succeeded by bluish berries. Its handsome, deep green, glossy foliage and neat habit render it very popular for decorative planting.

\section{Rhododendrons. Rosebay}

The Rhododendrons are magnificent flowering Evergreen Shrubs. All require a peaty soil and a somewhat shaded situation. We offer only the hardiest varieties.

Rhododendron maximum (Great Bay). July. This is the noblest of'all our native shrubs, and is absolutely hardy from Vermont to Georgia. It has the most beautiful foliage of any kind of Rhododendron, it being a bout twice as large as that of other sorts, and very thick and smooth.

Catawbiense. June. This is a native, close-growing form with handsome foliage and large trusses of deep rose flowers. A splendid variety to group with high-colored forms as its foliage effect can be depended upon.

Catawbiense grandiflora. The foliage effect is similar to the preceding, but of darker, richer green. Flowers deep rosy-purple, borne in great prof usion.

Cunninghami. Pure white flowers.

Pontic um. Rosy pink flowers.

\section{Named Hybrid Rhododendrons}

The varieties we list have been well tested and we confidently offer them as hardy in New England, consequently adapted to other parts of the country, except in extreme northern latitudes.

\section{Varieties}

Abraham Lincoln. Rosy crimson.

Album elegans. Blush, changing to white.

Boule de Neige. Pure white; very hardy.

Caractacus. Rich purplish crimson.

Charles Dickens. Dark scarlet.

Everestianum. Rosy lilac, spotted red.

General Grant. Crimson pink.

Giganteum. Bright rose.

Gloriosum. White; bold flowers and good foliage.

Lady Clermont. Red, shaded crimson.

Roseum elegans. Vivid_rose; beautiful. 


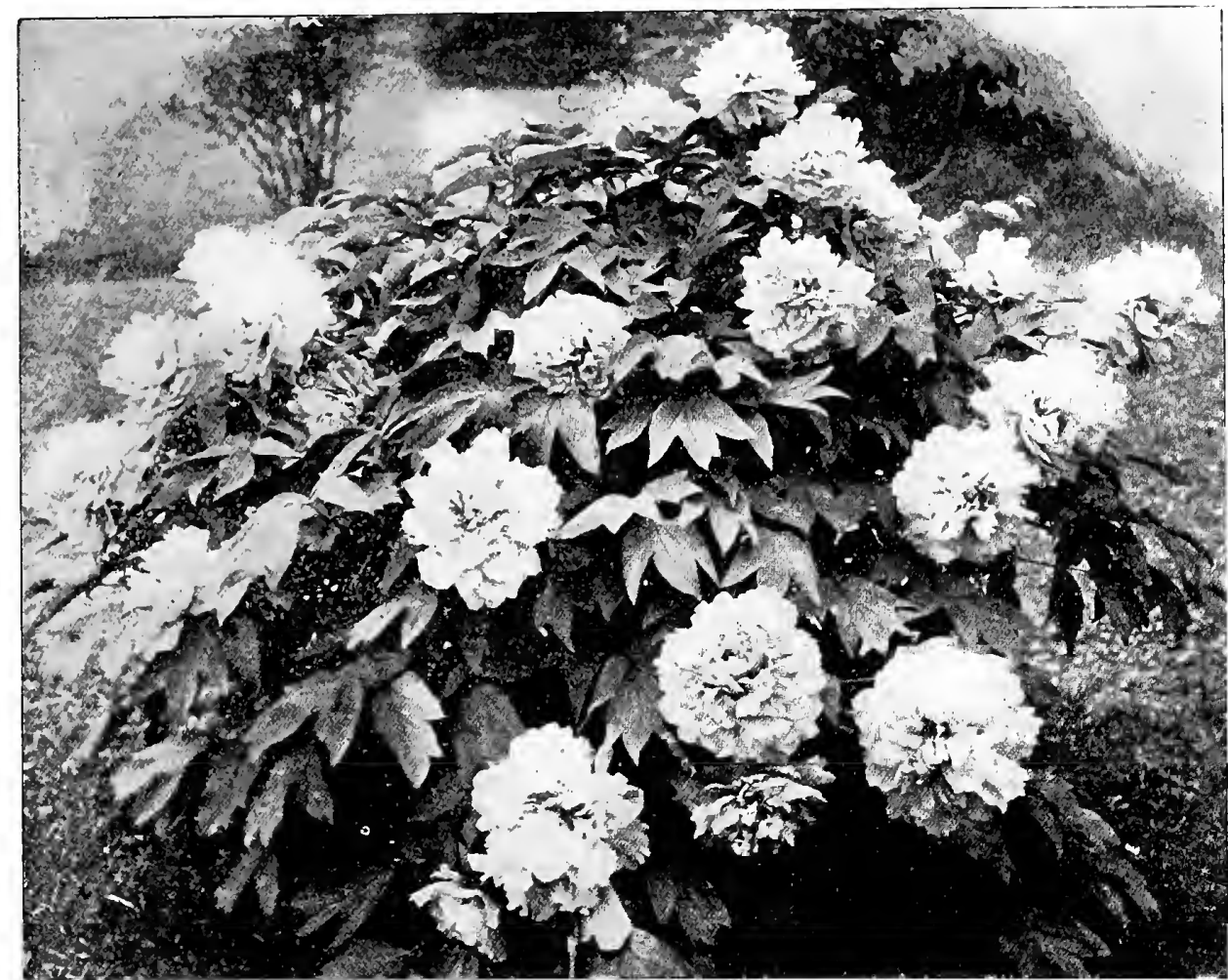

TREE PAEONIA

\section{PEONY}

TREE OR MOUTAN CLASS

Handsome flowering shrubs, attaining from 3 to 4 feet in height, with proper care. The flowers are remarkably beautiful and striking, very numerous and enormous in size, often measuring 6 to 8 inches across, and appear in May and June. Although hardy, the plants are greatly improved by a slight protection in winter.

\section{HERBACEOUS CLASS}

Pæonies should be planted in good rich, deep, moist soil after which they require less attention than any other class of flowering plants.

They are perfectly hardy and their remarkable freedom from disease and insects make them most desirable.

Some of the varieties are of enormous size, perfectly double and deliciously fragrant. In color the Pæonia rivals the Rose in beauty ranging from pure white to darkest red and the shades of pink are truly magnificant. Pæonies thrive in all locations whether in the broad sunlight or in partial shade.

Our blocks attract hundreds of visitors every year.

Augusta Mielley. Outside pink, center yellow to pink, red stamens.

Active. Pink, bud very large and round, full, double, late.

Alba Superba. White, large and full touched with carmine.

Amabilis Grandiflora. White, very large, double, fringed petals, fine, very sweet.

Amabilis Speciosa. Rose, fading to white, large, very double, sweet.

Baron Rothschild. Outside petals rose, center salmon, sweet, distinct.

Bicolor Mad. Guerin. Fine red; rosy center.

Bicolor. Pink, center whitish pink.

Blushing Bride. Light rose, nearly white.

Buckii. Light crimson, double, large, rose scented.

Carmen. Outside carmine, center rose.

Clarisse. White touched with carmine, outside petals light pink.
Carnea Eleganus. Outside petals shell pink, center white, red stamens.

Chrysanthemifolia. Pink, slightly yellow at center.

Candida fl. pl. Dark red outside petals; rosy white center; very fine.

Caroline Mather. Purple crimson, very large, double and very dark.

Couronne de Roses. Dark rose; soft rose center.

Delecourt Verhille. Pure white, carmine spotted.

Delectissima. Purple rose, large, full, fine, sweet, center salmon.

Diamond. Large, white, fragrant.

Doyenne d'Enghein. Violet rose and carmine.

Duchesse de Nemours. Rose pink, very large, double, sweet; one of the best.

Dugueslin. Rosy carmine.

Elegans. Outside petals dark pink, large salmon center, loose, fine, sweet.

Dr. Nestor. Carmine. 


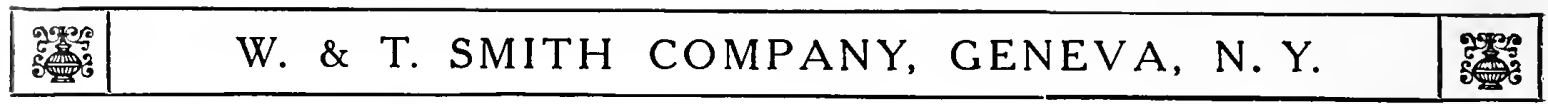

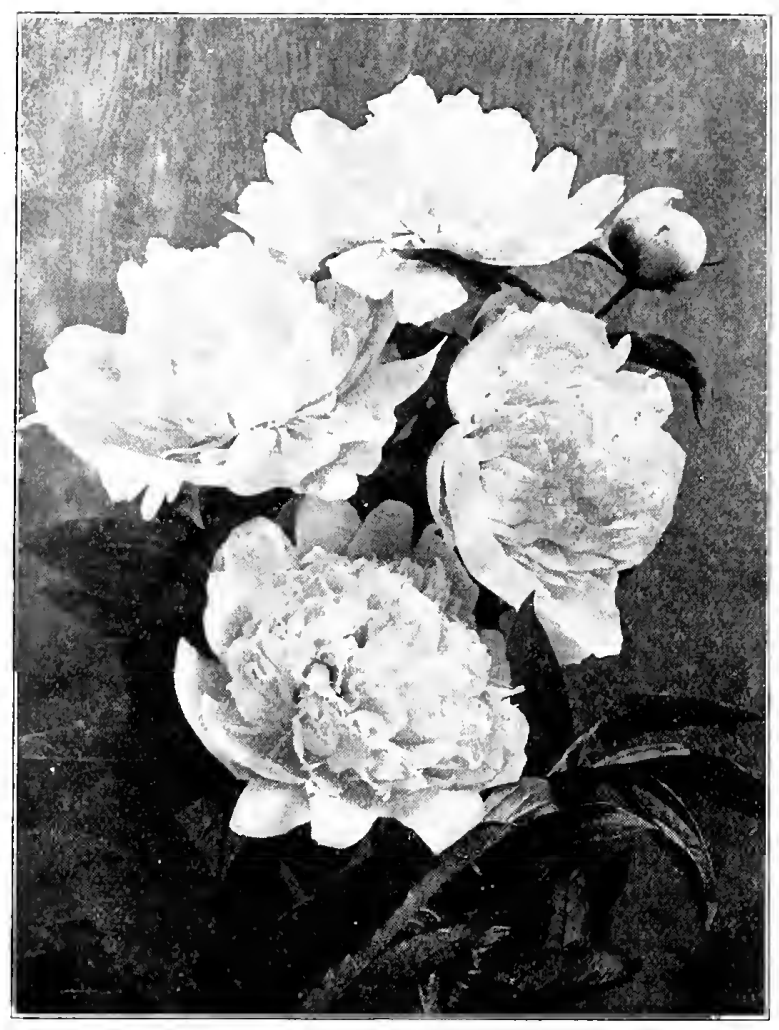

Peony Festiva Maxima

Exposition Universale. Outside shell pink, yellow center.

Faust. Outside shell pink, yellow center spotted with carmine.

Festiva. White, outside petals shell pink.

Falliers. Purple crimson.

Festiva Maxima. Creamy white with small center of carmine; round, early in clusters, sweet. late.

Fragrantissima. Violet and rose color, very sweet,

Francis Ortegal. Dark purple crimson, very large, fine, deep, double and sweet.

Fulgida. Very dark crimson, good.

Humei Carnea. Shell pink, carmine spotted.

Geldorf. Soft red; extra fine.

Humei. Rose, full, large, late; one of the best.

King of Roses. Deep rose; sweet-scented.

La France. Pink outside petals with yellowish center; very fine.

L'Innocence. White; rosy outer petals.

La Martine. Bright red, full, good.

Mad. Lemans. Shell pink outside, canary yellow center.

Lucrece. White, yellow center.

Modeste Guerin. Rose salmon on center.

Mad. Waroguiet. Outside petals purplish rose, center shell pink to carmine.

Maiden Blush. White and light rose.

Mary Hamilton. Satin rosy red.
Mary Stuart. Rosy white, creamy center.

Mad. Breon. Outside petals rosy flesh, center white and yellowish, turning to pure white.

Officinalis:

Var. Alba Plena. Double white, tinged red.

Var. Rosea. Double crimson changing to rose, fragrant; fine.

Var. Rubra. Dark red; very early.

Osiris. Rosy carmine.

Queen's Perfection. Outside pink, center white, red stamens.

Plenissima rosea superba. Shell pink to carmine center.

Perfection. Outside petals rose lilac, inside salmon, sweet.

Pius IX. Dark red purple, semi-double.

Prolifera Tricolor. Rosy white, center yellow with carmine spots.

Pulcherrima. Bright satin rose; center blush white.

Purpurea. Delicate purplish carmine.

Reine Hortense. Pink, large, full, globular, fine, fragrant.

Rosa Grandiflora. Rose crimson, very double, early.

Salvator. Rose; white center.

B. Rendather. Clear violet red.

Sweetheart. Red, white and rose center.

Tenuifolio flore pleno. Deeply cut fringe-like foliage. Flowers bright scarlet crimson, quite double and globular; rare and fine.

Triumph du Nord. Violet rose, lilac shade.

Triumph de Paris. White; center yellowish, outside petals pink.

Variegated. Pink and salmon variegation, semi-double, sweet.

Victoria. Rose, center yellowish.

Victor Lemans. Rosy outside, center white, carmine spotted.

Washington. Violet rose.

Wilhelmina. Fine soft rose outside; center white to yellow.

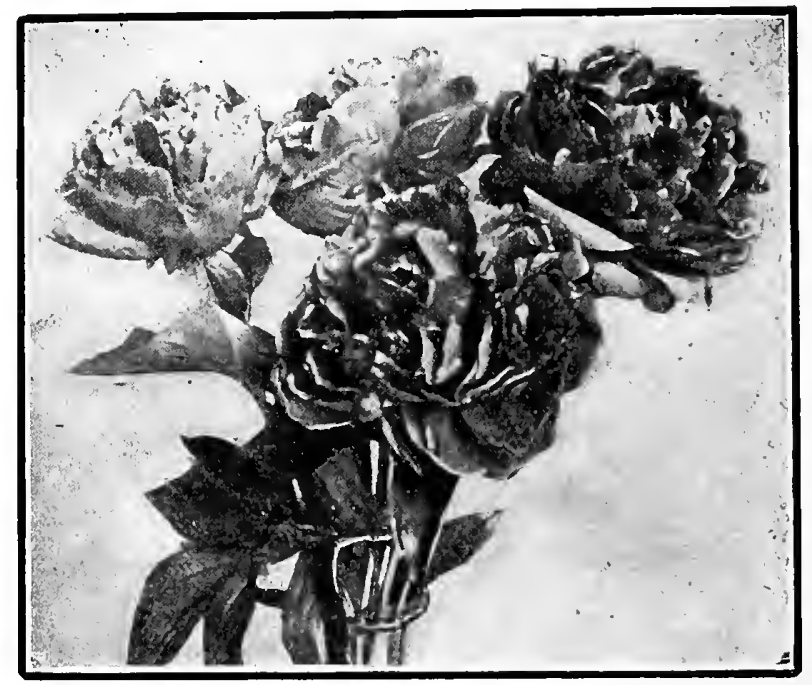

Triumph du Nord 


\section{BULBS AND BULBOUS FLOWERING ROOTS}

The classes and varieties of Bulbs are so numerous that limited space does not admit of our enumerating them in this catalogue. Suffice it to say, we can supply anything in the bulbous line possessing merit, and will be pleased to answer all queries regarding same.

SUMMER AND AUTUMN FLOWERING BULBS THAT REQUIRE TAKING UP IN THE FALL, AND TO BE KEPT IN A DRY CELLAR FROM FREEZING

\section{GLADIOLUS}

These handsome, stately flowers are universally popular. They are robust, erect of growth, with green sword shaped leaves, and splendid flower scapes rising from two to three feet in height. They are of a variety of colors, such as orange, scarlet and vermillion tints upon yellow and orange grounds, with various shades from white and rosy blush and salmon rose tints to a salmon red and nankeen.

\section{TUBEROSE}

The TUBE Rose is noted for its delicate beauty and exquisite fragrance; the flowers are pure white very double and wax-like, and borne on stems two or three feet high.

BULBS THAT SHOULD BE PLANTED IN THE FALL

\section{LILIES}

The lilies should have a place in every garden as they are entirely hardy, require little or no care and make a grand display; after planting they require very little care, and should not be disturbed for several years, as established plants bloom more freely than if taken up annually.

\section{CROCUS}

These are delicate and tasteful in form and varied and gay in color. Until the flowering of the Hyacinth and through the most changeable and unpleasant of the spring weather the garden depends almost alone upon the Crocus for its brightness. Plant the bulbs in autumn about three inches apart and cover with two inches of soil. Cover in fall with a little straw or coarse manure to keep the bulbs from being thrown out by frost.

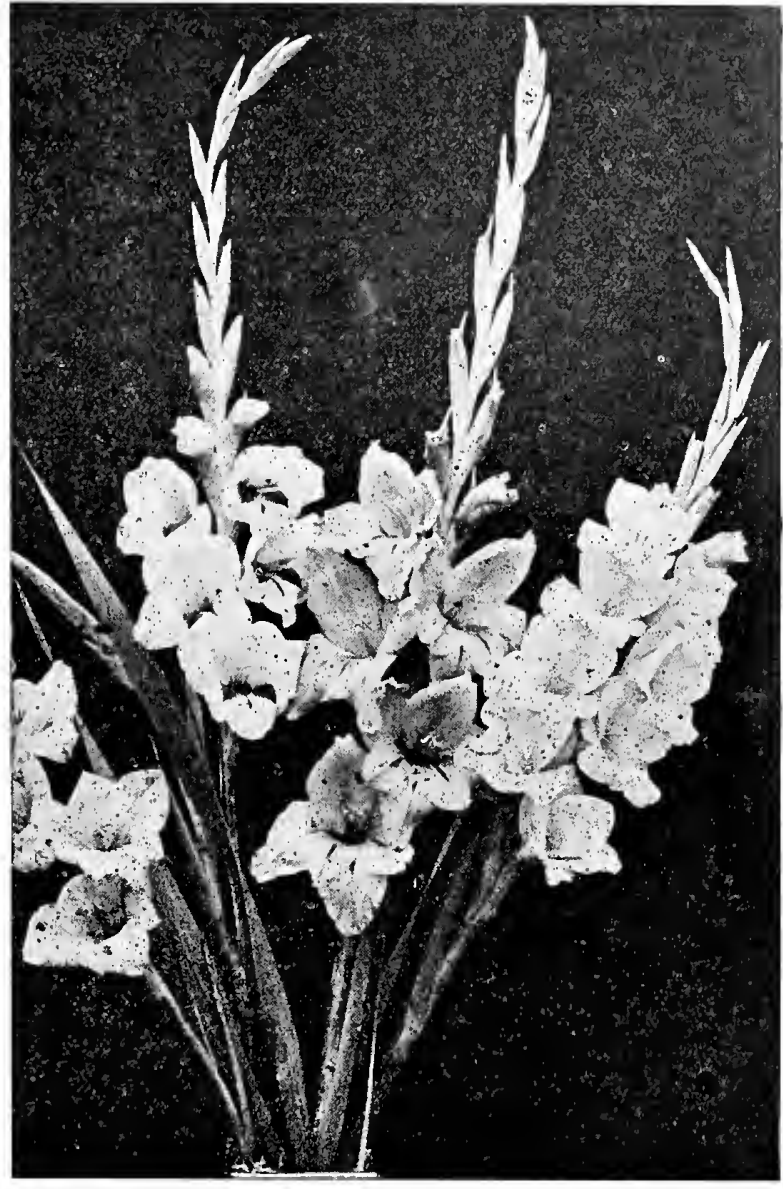

GLADIOLUS

\section{HYACINTHS}

Among all the bulbs used for winter flowers, the ${ }_{t}$ HYACINTH stands foremost. Flowers may be produced by placing the bulbs in a glass filled with water or placed in pots or boxes in soil. Double blue, with various shades; double red with verious shades; double white; single blue, various shades; single red, various shades; single white.

\section{TULIPS}

We have a splendid assortment of fine colors, both single and double. Early and late varieties prolong the season of bloom. Plant in the fall.

\section{CANNAS} ductions.

Tall growing tropical foliaged plants of great beauty. We can supply in great variety, including all the late intro-

\section{DAHLIAS}

We have added to our collection of this superb plant many new ones. No plant is more easy of culture and none show such a vast range of colors and combinations and give such a profusion of autumn bloom as the old dahlia and its
new varieties.

We can now offer New Large Flowering and Pompon varieties, also Single Dahlias, New Cactus and a large list of old standard varieties with an extensive range of color. 


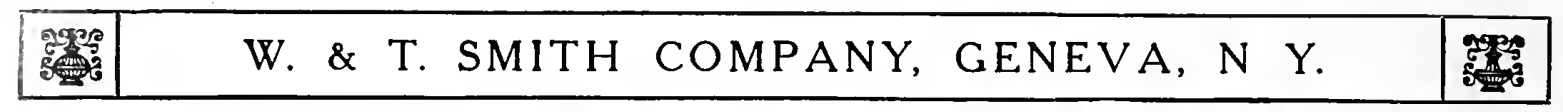

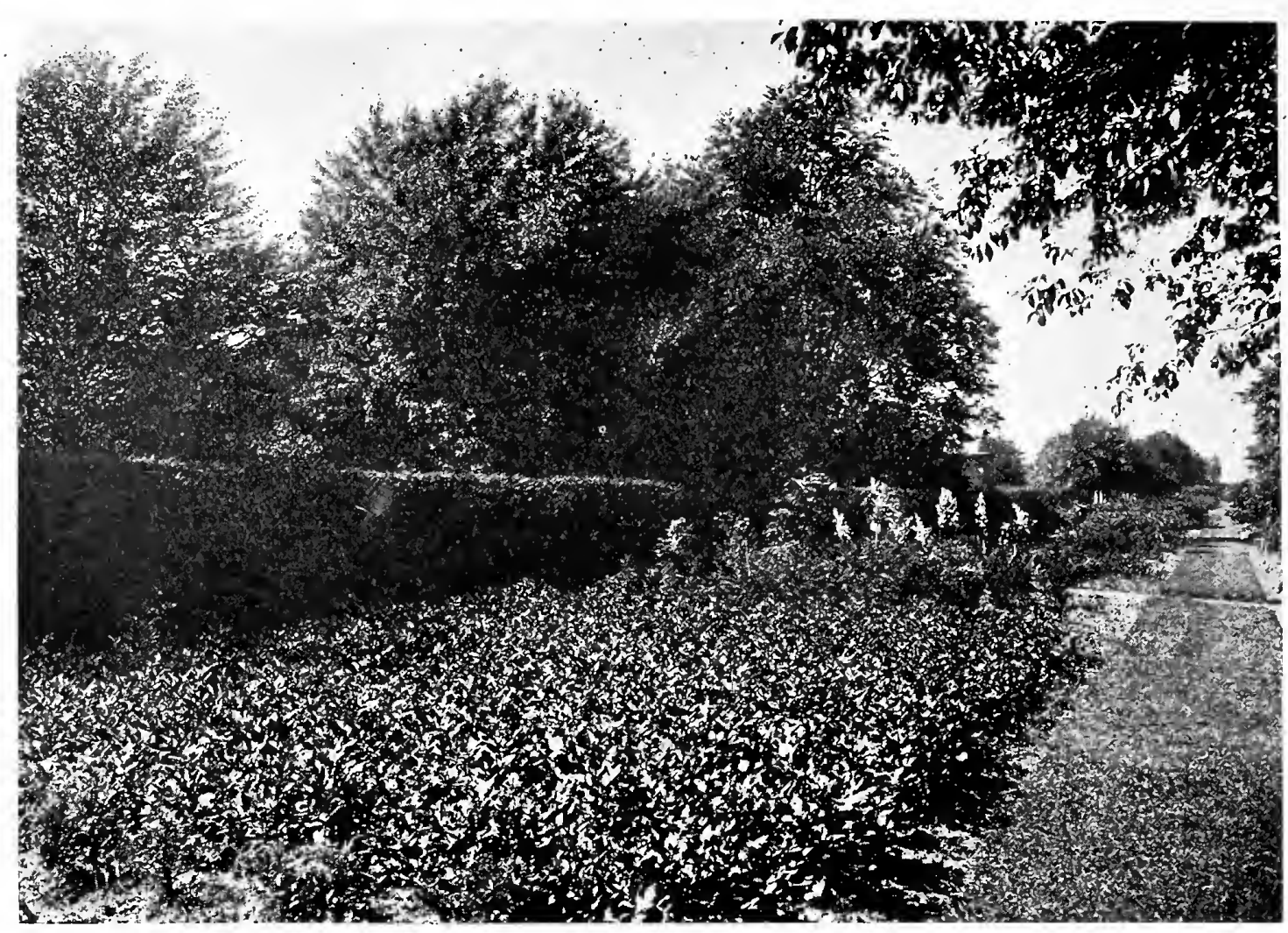

PERENNIAL BORDER IN OUR NURSERY. Norway Spruce Hedge in Background.

\section{Althea Rosea. Hollyhock}

If planted in good, rich, moist soil, they are satisfactory perennial plants. The double sorts are very fine, growing on tall stems, remaining in bloom for a long time. We offer a great variety in colors.

\section{Achillea. Yarrow}

A. Ptarmica (The Pearl). Small double white flowers very valuable for borders and gardens, a profuse bloomer.

\section{Anchusa. Alkanet}

A. Italica. Dropmore VARIETy. A fine species, with rough leaves and stems, and fine blue flowers. June to August.

\section{Anemone. Wind Flower}

A. Japonica. A distinct and beautiful species; flowers $21 / 2$ inches in diameter; bright purplish rose, with golden yellow centers, borne in great profusion from September to November.

var. alba (Honorine Jobert). A distinct and beautiful variety of the preceding; pure white, center golden yellow.

var. Queen Charlotte. Flowers very large, well-formed, semi-double, and of a beautiful rosy flesh color on the upper side and of darker shade underneath.

var. Whirlwind. A variety producing double white flowers in great profusion in the autumn.

\section{Aquilegia. Columbine}

A. alpina. A native of the higher parts of the European Alps. Stems 9 to 18 inches high, bearing showy blue flowers.

A. cærulea. Rocky Mountain Columbine. Flowers large, blue sepals, white petals, long recurved spurs.
A. canadensis. WILd Columbine. Our well-known native species, with scarlet sepals and bright yellow petals.

\section{Arundinaria. Ribbon-Grass}

A. foliis variegatis. VARIEGATED RIBBoN-Grass. One of the prettiest hardy grasses, with handsomely striped foliage.

\section{Asclepias. Milkweed. Silkweed}

A. tuberosa. Butterfly Weed. Pleurisy Root. Bright orange flowers; showy and beautiful; 2 feet.

\section{Aster. Starwort or Michaelmas Daisy}

A. Airship. Pure white.

A. Bessarabicus. Large, violet-blue flowers.

A. coccineus Nevadensis. Red, yellow center.

A. decorus. Mauve lilac; very free flowering.

A. ericoides. Heath-LIKe Aster. White flowers.

A. grandiflorus. Violet-blue.

A. Himalayensis. Small white flowers.

\section{Astilbe. Japan Spiræa. False Goat's Beard}

A. Davidii. Spikes of deep rose-violet flowers on stems 3 to 6 feet high. July and August.

A. Gladstone. Large trusses of pure white flowers.

A. Japonica. Known generally as Spiræa Japonica or Hoteia Japonica. A handsome plant.

\section{Boltonia. False Chamomile}

B. asteroides. Large white flowers, tinged with pink; 4 to 5 feet. September. 
B. latisquamæ. Aster-like flowers in a broad head; rosy purple; free blooming, showy and fine; 5 feet. July to October.

\section{Bellis. Daisy}

B. Bride. Pure white; double.

B. Longfellow. Pink; double.

\section{Campanula. Canterbury Bell}

C. Medium. Flowers blue, white and rose, corolla very large and bell shaped.

\section{Cassia. Wild Senna}

Cassia Marylandica. 3 to $4 \mathrm{ft}$. July to September. A showy valuable plant; easily grown. even on poor soil. Very ornamental foliage, and immense heads of yellow, pea shaped flowers.

\section{Chrysanthemum}

c. leucanthemum "Shasta." Shasta DAIsy. Large white flowers, blooming throughout the summer.

var. Alaska. An improved form; flowers 4 to 5 inches across.

C. Bronze Red. Pompon.

C. Zenobia. Yellow; pompon.

C. Pompon. Crimson and white.

\section{Coreopsis. Tickseed}

C. auriculata. A showy perennial; flowers solitary, on long stalks; yellow; 2 to 3 feet. June.

C. grandiflora. Large yellow flowers on long stems; early summer until frost.

C. lanceolata. Large golden yellow flowers; profuse bloomers.

\section{Convallaria. Lily of the Valley}

C. majalis. LILY OF THE VALLEY. Large, luxuriant foliage; flowers small, bell-shaped, in pretty racemes, and very fragrant.

\section{Daphne}

D. Cneorum. Garland Folwer. A pretty dwarf, evergreen shrub, bearing a profusion of rosy lilac flowers in May.

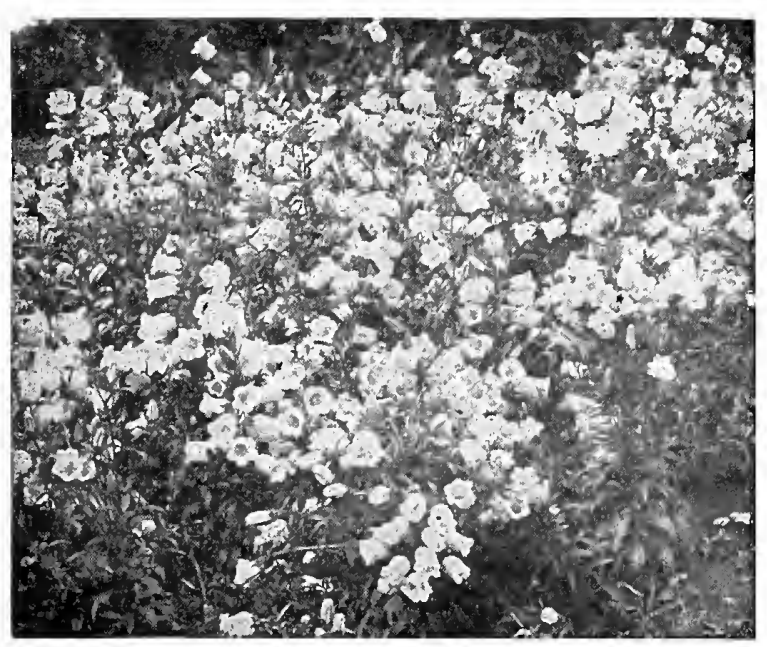

Canterbury Bell.

D. pendulifolium. A native of Japan. Shrub-like appearance, with numerous graceful and drooping branches from which hang great numbers of flower clusters. The flowers are pea-shaped, of a light purple color.

\section{Delphinium. Larkspur}

D. Belladonna. Sky-blue. June to Oct.

D. Chinensis grandiflora (Chinese Larkspur). Blue. July to Sept.

D. var. alba. White. July to Sept.

D. var. elatum (See Larkspur). Violet-blue. June to Sept. Flowers in long and heavy spikes. July.

D. formosum (Oriental Larkspur). Blue. June and

D. var. cœlestinum. Light blue. June and July.

\section{Dianthus. Pink}

D. barbatus (Sweet William). Among the most esteemed and valuable of hardy plants, producing flowers of a great variety of colors. Mixed colors.

\section{Dicentra or Dielytra. Bleeding-Heart}

D. eximia. Rose color; foliage fern-like; flowers all summer.

D. formosa. Bright red flowers in May.

D. spectabilis. A handsome, most curiously formed, rosy-crimson flower, with white and blue tinged protru ding stamen.

\section{Dictamnus, Fraxinella, or Gas Plant}

D. alba. White. June.

D. Tubra. Red. June.

\section{Digitalis. Fox Glove}

D.Igrandiflora. Yellow. June and July.

D. purpurea (Foxglove). Purple. June to July.

D. Var. gloxiniæflora. White to pink. June and July.

D._var._alba. White. June and July. 


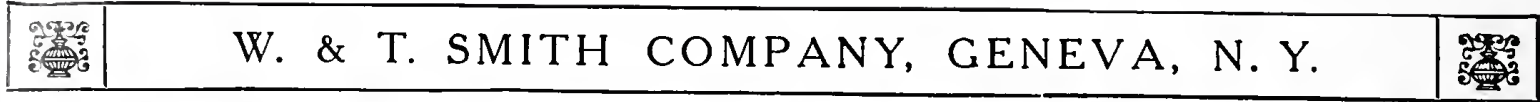

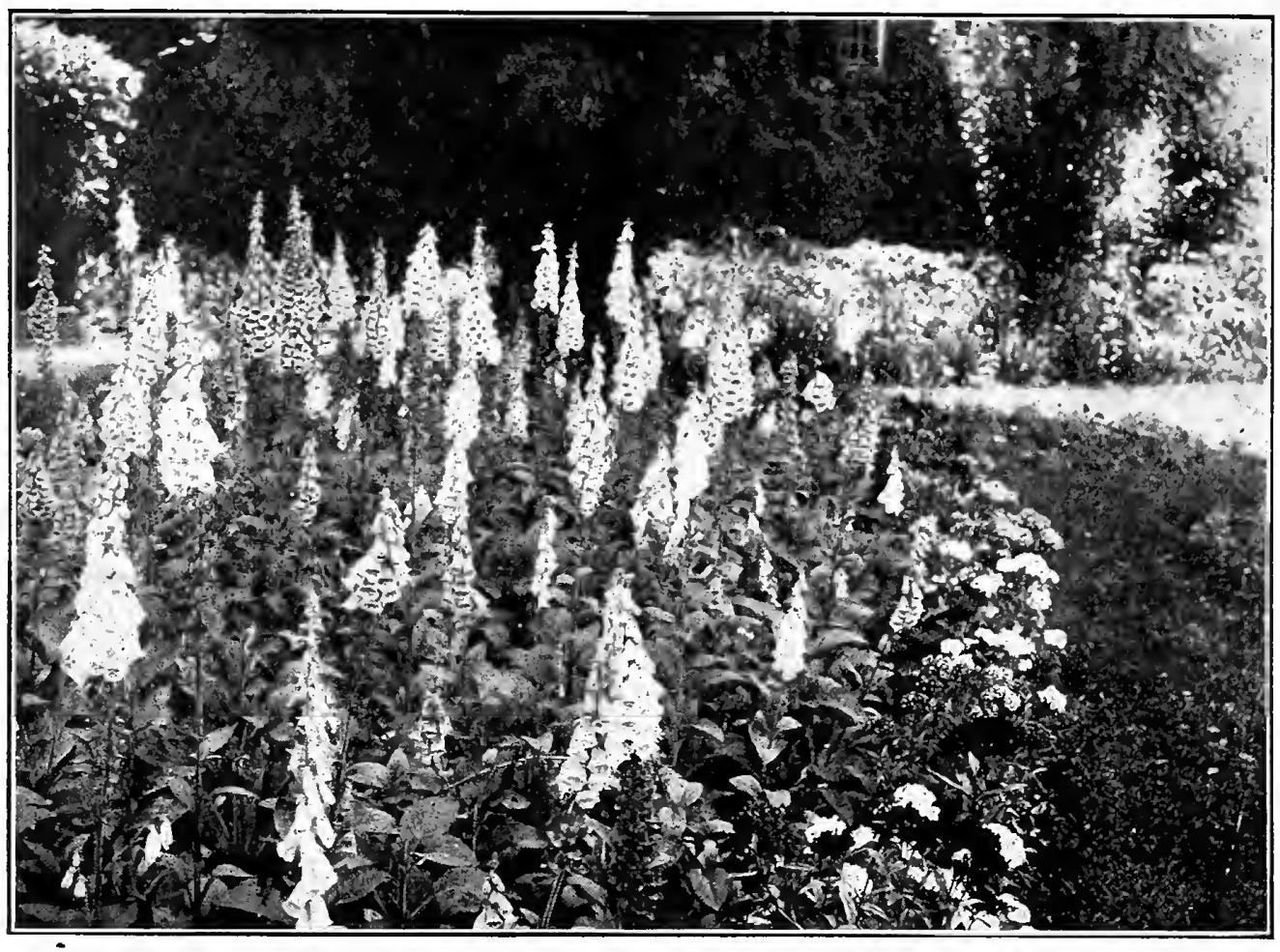

BED OF DIGITALIS WITH BORDER OF HARDY DIANTHUS

\section{Eulalia}

E. gracillima. Leaves narrow and dark green.

E. Japonica. Foliage deep green and graceful. Flower panicles brownish violet.

E. var. zebrina. Plume. Oct. Bars of yellow rinning crosswise of the leaves.

\section{Erianthus. Ravenna Grass}

E. Ravennæ. Resembles the Pampas Grass, but blooms more abundantly. Attains a height of from 9 to 12 feet. Being perfectly hardy, is a valuable grass for the decoration jof lawns.

\section{Funkia. Day Lily}

F. lancifolia. Pale lilac. July to Sept. Flowers in spikes.

F. subcordata grandiflora (White Day Lily). White. Aug. and Sept.

F. undulata variegata. Lilac. Aug. Foliage white and green varigated.

GAILLARDIA grandiflora (Blanket-Flower). Crimsonorange. June to Nov. Flowers very large and good for cutting.

\section{Helianthus. Perennial Sunflower}

H. Maximiliana. Long, narrow, willow-like leaves graceful and stately. September.

\section{Helleborus. Hellebore. Christmas Rose}

H. niger. Beautiful white flowers in March or April.

\section{Hemerocallis. Day Lily}

H. aurantiaca major. Flowers orange colored; fine.

H. flava. (Yellow Day Lily). One of the finest hardy plants; flowers large in clusters, golden yellow, and very fragrant; plant vigorous. June.

\section{Hibiscus. Rose Mallow}

H. moscheutos. Swamp Rose MaLlow. Flowers varying from light purplish red to nearly white with darkec eyes.

var. albus. Crimson Eye. Large, showy, white flowers, crimson eye in August.

\section{Iris. Fleur de Lis}

I. Japonica. JAPANESE IRIS (KAEMPferi). The flowers are broad and flat. They exhibit a wonderful variety of colors and shades and appear later than the others. They rank among the most desirable of hardy plants; succeed best in a moist soil.

Germanica. German IRIS. This group blooms early and with wonderful combinations of coloring. Easily distinguished from other Iris by their broad sword-like leaves. We offer eight named varieties.

\section{Lychnis. Lamp Flower}

L. Chalcedonica. SCARLET LychNis. Brilliant scarlet. June and July.

var. alba. A form of the preceding with white Howers.

\section{Platycodon. Campanula}

P. grandiflorum. Large, fine blue flowers. June and July.

P. grandiflorum alpum semi-pleno. White.

\section{Primula. Primrose}

P. acaulis. Common EURopean Primrose. A fine collection.

P. veris. Cowslip. Flowers bright yellow in terminal umbels, in spring and early summer.

P. vulgaris. ENGLish PrIMROSE. Bright canary yedlow. 


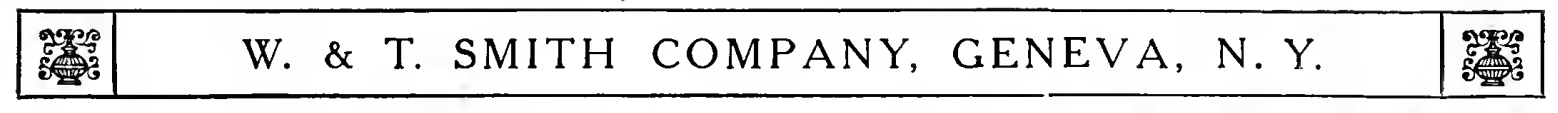

\section{Rudbeckia. Golden Glow}

A glorious new plant, and one that will find a place in every garden here and abroad; of fine habit, vigorous growth, with early, continuous and immense blooming qualities.

\section{Hardy Phlox}

Amazone. Pure white.

Richard Wallace. Pure white, rosy crimson eye.

Coquelicot. Fiery red.

Eiffel Tower. Pink.

Lothair. Salmon, crimson eye.

Wm. Robinson. Pale salmon, rose center.

Eclaireur. Bright rose carmine.

Miss Lingard. White, light lilac eye.

Flambeau. Bright orange red.

Le Soleil. Bright magenta salmon.

\section{Salvia. Sage}

S. azurea grandiflora. Bright blue in great profusion during August and September.

S. bicolor. Blue and whitc.

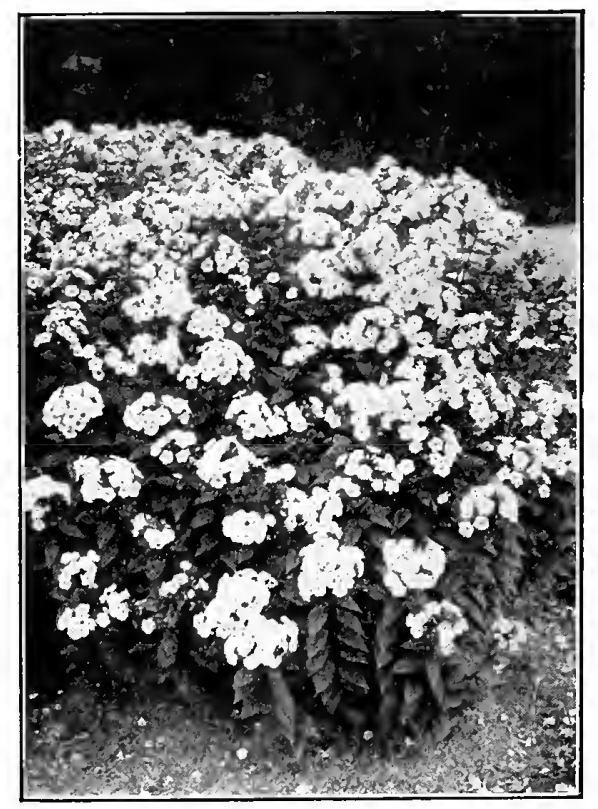

Phlox

\section{Spiræa.} Meadow-iSweet

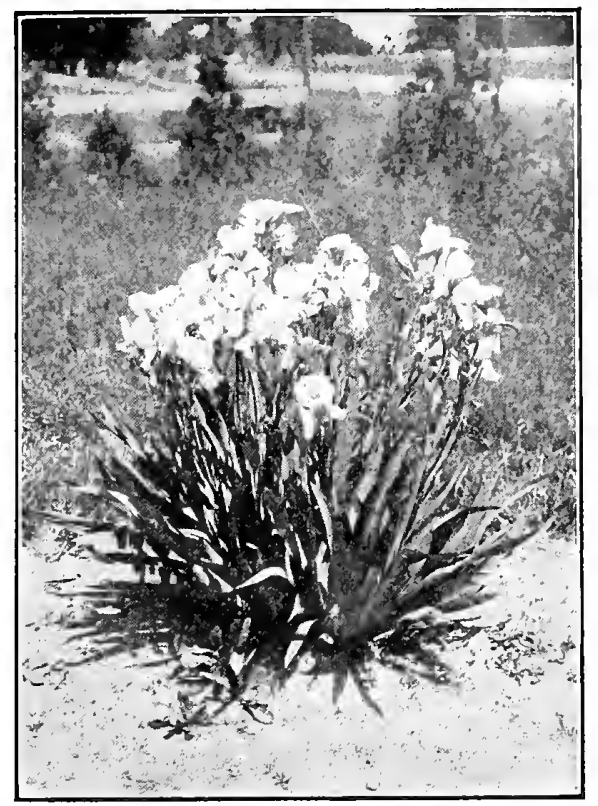

Iris

S. Aruncus. Goat's BEARD. Large panicles of creamy-white flowers; one of the best border plants. June.

S. astilboides. White flowers in panicles; fine; June.

var. floribunda. White flowers: compact and graceful.

Filipendula. Dropwort. Large showy heads of white flowers, tinged with rose. June.

\section{Stokesia. Stoke's Aster}

S. cyanea. A native species producing beautiful sky-blue flowers like a China Aster; September until frosts.

var. alba. A variety of the preceding with white flowers.

Tritoma. Kniphofia. Flame-flower. Torch Lily. Red Hot-Poker

T. Pfitzeri. Orange scarlet flowers from August to November; very showy.

\section{Veronica. Speedwell}

V. amethystina. Amethyst blue. June.

V. gentianoides. Pale blue, with azure. May and June.

V. incana. Amethyst blue flowers;silvery foliage; July and August.

V. longifolia $\mathrm{sub}-$ sessilis. Flowers of a beautiful amethyst blue; extra fine. August to October.

\section{Vinca. Myrtle, or Periwinkle}

V. cærulea minor. A blue flowering,"trailing evergreen. var. argentea marginata. White edged leaves.

V. elegantissima alba. White flowers: and glossy green oval foliage.

V. herbacea. Blue flowers; early; narrow foliage; very pretty.

V. major variegata. Trailing habit, leaves broadly margined with yellow. A fine basket plant.

\section{Yucca. Spanish Bayonet}

Y. filamentosa. Adam's NeEdLE. Thread-leaved; creamywhite. July.

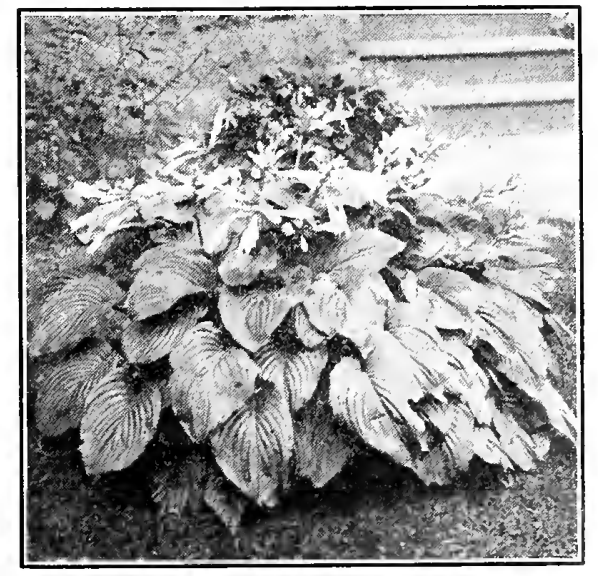

White Day Lily 


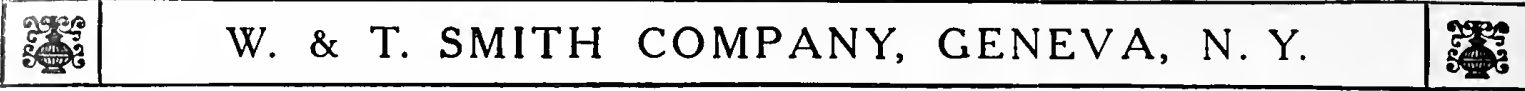

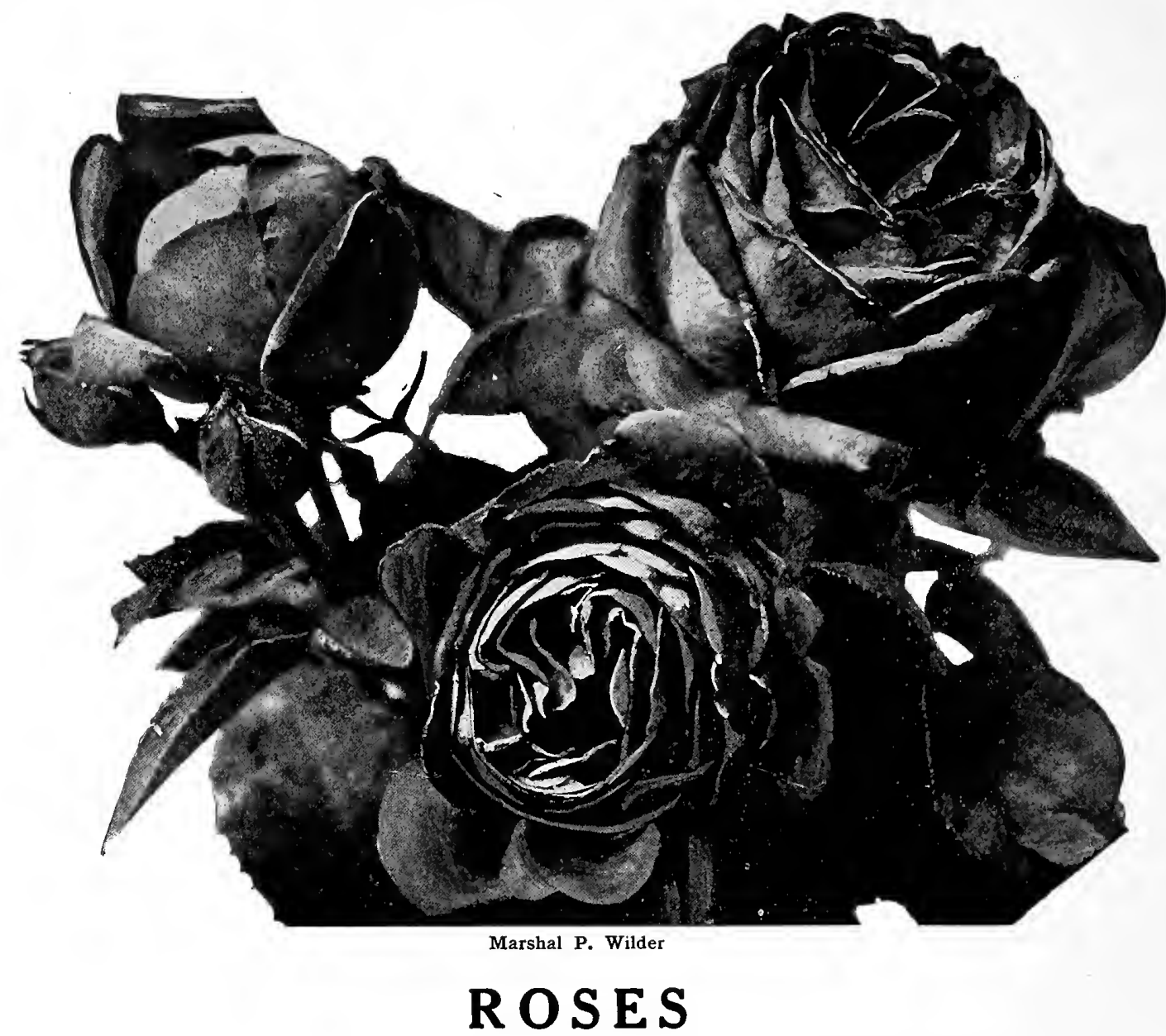

Very great progress has been made within the last few years in rose culture and the best list of roses of today would not contain many varieties that were the best a few years ago. From the ends of the earth new varieties and new species are gathered, new hybrids are produced and new seedlings are grown from which careful selections are made, and it is truly wonderful what the results have been up to date. About all that is desirable in a rose has been obtained in color, size, fragrance and hardiness.

Na As roses are raised mostly for their flowers, it is necessary to give that culture to the plant best adapted to produce this result. A very rich soil is of the first importance and it must be made so by thoroughly working into it plenty of old composted stable manure in which leaf mold has been decomposed.

Hardy sorts of roses may be planted in the fall or spring. All roses should be severely cut back at the time of planting, and thereafter every spring.

Hybrid Perpetual Roses may be cut back immediately after flowering to ensure new growth and increased blooming the same season.

\section{WINTER PROTECTION}

All roses in this climate will give better results if protected in the winter. The best way is to cover the plants with dry leaves kept down by evergreen boughs all of which should be removed early in the spring.

\section{INSECT REMEDIES}

For any insect that eats the foliage, a dusting of the damp leaves with white hellebore will be safe and sufficient.

For thrips and aphides a spraying or wash of whale oil soap will be effective.

If mildew appears, sprinkle the moist leaves with dry powdered sulphur or sprinkle with sulphide of potassium dissolved in water. A cubic inch to a gallon of water.

\section{REMARKS}

There are thousands of varieties of roses grown and we have been testing and selecting for years to secure a satisfactory list for ourselves and our customers. The following varieties with brief descriptions, we regard as good a list as can be made, including some good old sorts and all desirable new ones.

Roses are divided into a number of classes which overlap each other so as to make much confusion. We have tried here to classify according to hardiness and blooming qualities rather than by the regular classification. 
The roses we offer are not the little soft plants grown as small as possible so as to send by mail, but good, strong two-year plants 18 to 30 inches high and well rooted. No statement is needed to convince planters which are best.

In describing roses we have used the following letters to designate the class to which each sort belongs:
H. for Hybrid Perpetual or Remontant.
H. T. for Hybrid Tea.
H. C. for Hybrid Climber.
s. for Summer.
N. for Noisette.
H. N. for Hybrid Noisette.
H. Ch. for Hybrid China.
P. for Prairie.

T. for Tea.

(Noisette, *Bourbon, Bengal or China and Tea). The following stock we keep in varieties, mostly in pots so they can be shipped at any season. They can be planted at any time out of doors or they can remain in the pots for house culture and winter blooming. Any treatment that will keep them growing will favor an abundance of bloom. Varieties marked $(\dagger)$ are usually hardy in the open ground in this section if suitably protected in winter.

Bengal or China Rose. A native of China. Of moderate branching growth, with flowers and foliage both small. They are not very hardy but with protection are valuable on account of the profusion of crimson buds which such sorts as Agrippina produce.

Bourbon. A hybrid of Bengal and Damask Roses. Quite hardy. Foliage dark and lustrous; habit vigorous; flowers are generally of light shades.

Noisette. Quite hardy. Flowers in small clusters and blooms very freely throughout the season. etc.

Tea. Native of China. Flowers valuable because of the beautiful buds. See Catherine Mermet, Perle des Jardines,

†Agrippina (Bengal). Velvet crimson, moderately double, fine buds.

†Appoline (Bourbon). Rosy pink, large cupped flowers.

$\nmid$ Bessie Brown (H. T.). It has unsurpassed beauty of a totally distinct character, bearing large, full, deep and double flowers, on strong, erect stems. The color is almost pure white, though sometimes flushed with pink; petals large and of fine form.

Bon Silene (Tea). An old rose, but unsurpassed for beauty of its buds. Light rose, sometimes rosy crimson.

Bride (T.). Pure white, large, fine. Very fragrant.

Bridesmaid (T.). Pink, rich color.

Catharine Mermet (T.). Bright flesh color with silvery lustre; large, double and very fragrant.

Duchess of Edinburgh (Bengal). Crimson bud changing light as it opens.

†Etoile de France (H. T.). The bushes are blooming constantly, producing large, massive, deep, full cup-formed flowers on magnificent, long, stiff stems. A clear red or velvety crimson.

Etoile de Lyon. A grand rose for forcing, of superb form and habit; color rich saffron-yellow, brighter in the center; very large and full, blooming profusely; grows vigorously.

$\nmid$ Fellemberg (N.). Rosy crimson.

†Francisca Kruger (T.). Coppery yellow shaded with peach, large and full.

Golden Gate (T.). The flowers are extra large and finely formed, with broad petals; of lasting substance buds long and pointed; color creamy white, delicately tinged with golden yellow and rose.

tGlorie de Dijon (Ch. T.). Combined colors of rose, salmon and yellow; large, full, globular; hardiest of Teas.

$\dagger$ Hermosa. Bright rose, flat form, very double; a constant bloomer and quite hardy.

Helen Gould (H. T.). One of the most valuable hardy everblooming roses. Flowers rich crimson, elegantly shaded.

$\nmid$ Kaiserin Augusta Victoria (H. T.). Delicate creamy white; free blooming; quite hardy.

$\dagger$ Killarney (H. T.). Color flesh, shaded white, suffused pale pink flowers; large buds, long and pointed; blooms profusely throughout the season.

†Liberty (T.). Beautiful deep crimson; free blooming, good bedding rose if protected.

†Mme. Lombard (T.). A good bedding rose; full flowers, very double and sweet; color a beautiful shade of rosy bronze beautifully shaded with carmine. Vigorous habit of growth; free and constant bloomer.
My Maryland. Another new hybrid of pleasing shade of pink and wonderfully productive. A favorite wherever seen. Strong, grafted plants.

$\nmid$ Maman Cochet (T.). Flowers large, full, clear carmine rose, shaded with salmon yellow. Plant very vigorous and free flowering.

† Marechal Neil (N.). Deep yellow, very large, very fragrant. The finest of roses succeed well only with best of care under glass.

Meteor (H. T.). Dark velvety crimson; constant bloomer; vigorous.

†Mrs. Robert Peary (H. T.). Climbing Kaiserin, free blooming and a very strong grower.

Papa Gontier (T.). Cherry red and glowing crimson; large size; constant bloomer; a fine rose for all purposes.

†Perle des Jardines (T.). Canary yellow, large, full, fragrant; foliage dark, glaucous and shiny. One of the best. †Queen's Scarlet (Bourbon). Rich velvety scarlet; a constant bloomer.

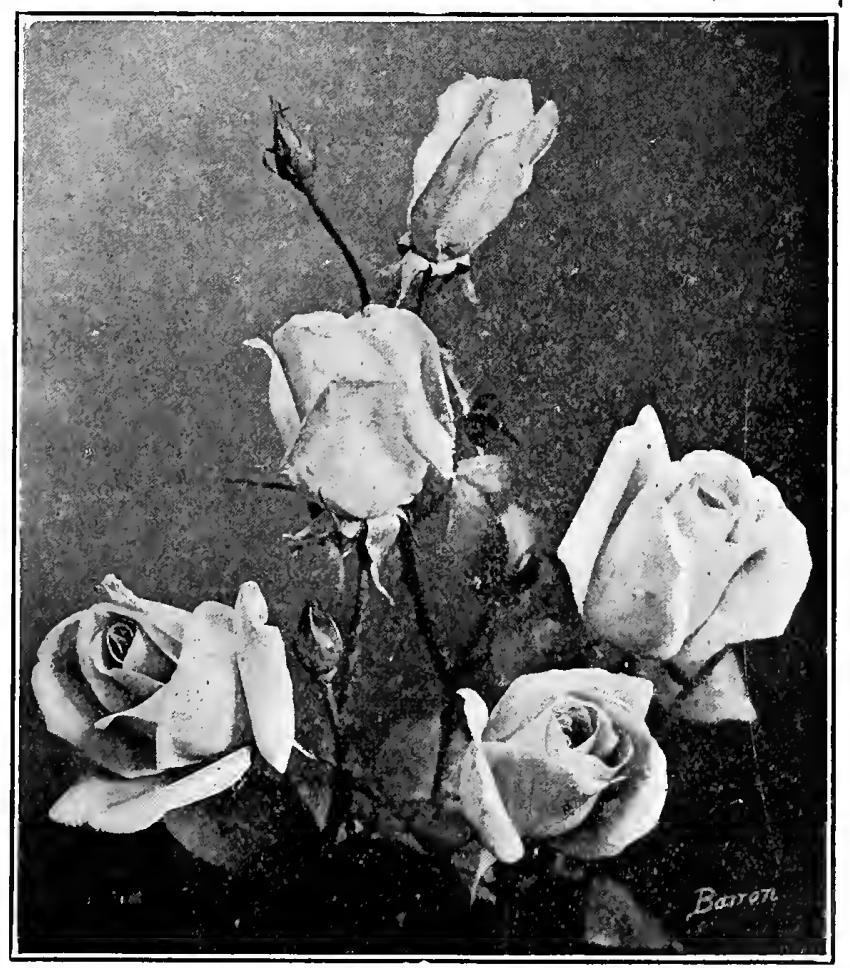

Killarney 


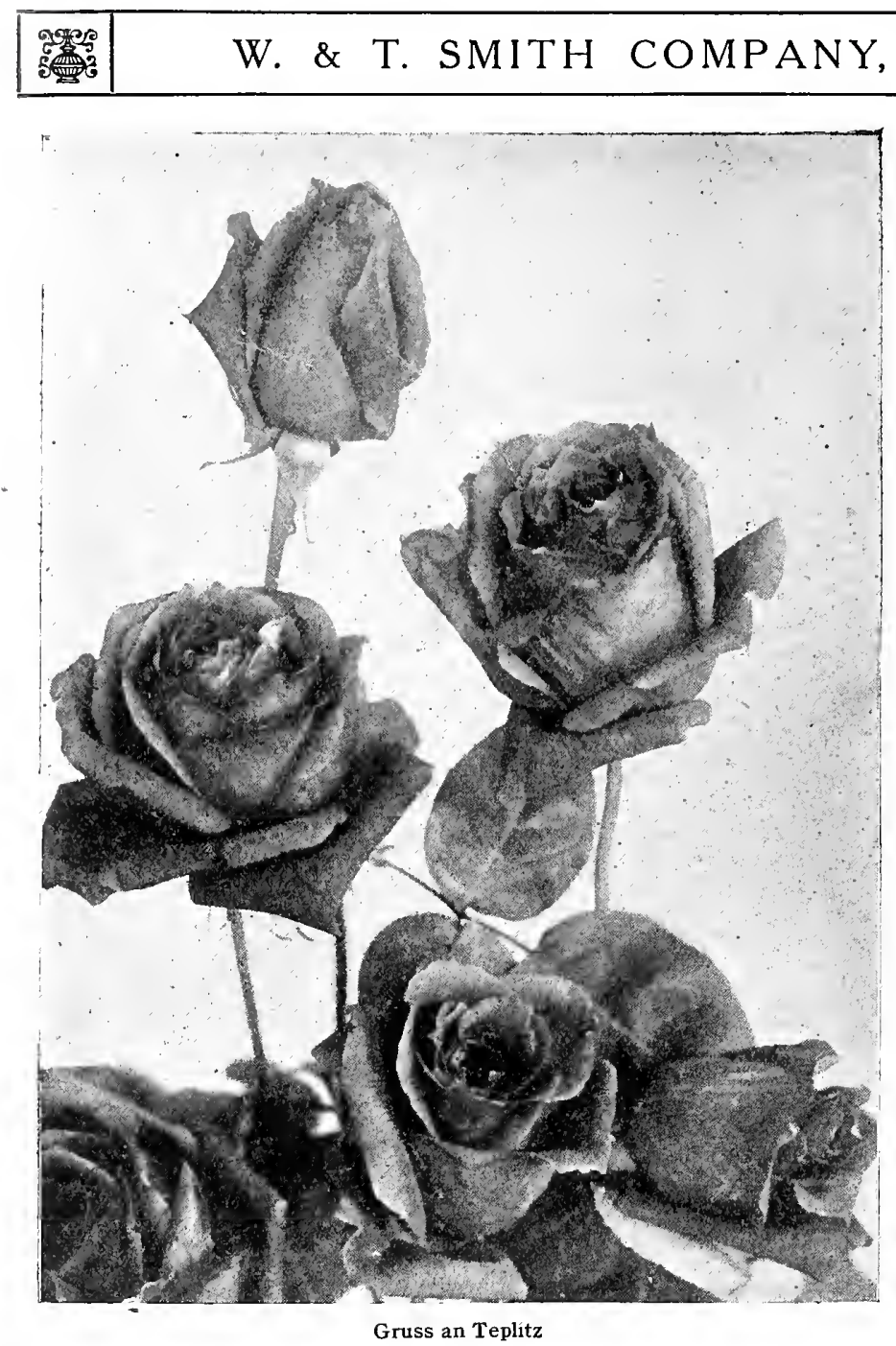

GENEVA, N. Y.

$\nmid$ Pink Soupert. Beautiful lively pink'; a great and constant bloomer and one of the best beddingiroses.

\section{Hybrid Perpetual or $\mathrm{Hybrid}$ Remontant Roses and Other Hardy Varieties}

Augustine Guinoisseau (H. T.). Flowers white slightly tinted with flesh. Sometimes called White LaFrance.

Alfred Colomb (H.). Cherry red, passing to bright rich crimson; flowers extra large, double and full; extremely fragrant and in every respect a superb sort.

American Beauty (H.). Large, globular; deep pink shaded with carmine; delicious odor; most desirable variety for forcing under glass.

Anne de Diesbach (H.). Brilliant crimson. A lsuperb garden sort; fragrant; one of the hardiest and best.

Baron de Bonstetten (H.). Rich dark red, passing to velvety maroon; highly fragrant. Very double.

\# Baroness Rothschild (H.). Light pink?; cupped form; very distinct and beautiful; one of the finest varieties; very hardy; a late bloomer.

*Black Prince $(\mathrm{H})$. Deep crimson; large size; full globular form; fragrant.

Caroline de Sansal (H.). Clear, delicate flesh color; fine form; a strong grower, and one of the best.

Captain Hayward. High-built, large, full, handsome flowers of crimson-carmine. Distinct, vigorous and free flowering.

Capt. Christy (H. N.). A very beautiful flesh-colored rose.

${ }^{*}$ Coquette des Blanches (H. N.). White; flowers of medium size, somewhat flat, but full and pretty; slightly fragrant; blooms in large clusters.

$\nmid$ Reve d'Or (H. T.). Fine, deep yellow, very fragrant. Richmond (H. T.). Brilliant crimson, large buds long and pointed.

$\dagger$ Red La France (Duchess of Albany). Resembles the Pink La France, but is much deeper in color. It is a continuous and free bloomer. Remarkably fragrant; color brilliant rose pink, exquisitely shaded.

Safrano (T.). Saffron and apricot yellow, large, semidouble, fine bud.

tSouvenir de Malmaison (B.). Flesh shaded with fawn, flat, full, very fine foliage, one of the best.

White Killarney. A white sport of the well-known "Killarney," with all the prominent and desirable qualities of that variety. Flowers large and pure white. A great acquisition.

tWhite Maman Cochet (T.). A sport from Maman Cochet, which it resembles in every particular except color, which is pure white, occasionally tinged with blush.

\section{Polyantha Roses}

†Cecile Brunner. Salmon pink with deeper salmon centre, fine in bud, and beautiful when open.

†Clothilde Soupert. Pearly white but variable, the same plant often producing red and white blooms; free bloomer and constant.

$†$ Mosella. This is a beautiful rose, with well-formed, very double camellia-like flowers, borne in clusters of two to five; the petals are white at the outside, with a yellow ground, and the center is a yellowish rose color.
*Coquette des Alps (H. N.). White, slightly shaded with pink, medium size; a profuse and constant bloomer, very full and fragrant.

*Duchess de Caylus $(\mathrm{H})$. Deep rich crimson, large, full, perfect flowers, very double and fragrant, a vigorous grower and a free bloomer, one of the best.

*Duc de Cazes (H.). Deep crimson scarlet shade, globular, vigorous.

Earl of Dufferin (H.). New. One of the finest roses of recent years, red and velvety crimson, shaded with dark maroon.

Fisher Holmes (H.). One of the choicest of perpetual roses. Bush is vigorous and produces freely of superb blossoms. Color brilliant carmine crimson.

*Francis Levet (H.). Cherry red; medium sized, well formed; very free bloomer.

*Frau Karl Druschki (or Snow Queen). Flowers very large, beautiful, pure silvery white, with very deep bud.

Gruss an Teplitz. Color scarlet shading to velvety crimson, very fragrant, a free grower and most profuse bloomer; handsome foliage, especially valuable as a bedding rose.

* General Jacqueminot (H.). Brilliant crimson, large and very fine, one of the handsomest and most showy roses of this color. Beautiful in the bud: semi-double when full blown.

Hugh Dickson (H. P.). Brilliant crimson, sháded scarlet, free flowering; very highly perfumed. 
Jubilee. Decp, flashing rrimson, with sharlings of velvety maroon; very large, and quite fragrant.

Jules Margottin (H.). Bright cherry red; large, well-formed fragrant flowers; very double and free.

John Hopper (H.) Bright rose with carmine conter, semi-globular, frec bloomer.

Lady Helen Stewart

(H.). New. Bright crimson scarlet; large, full and of perfect form.

${ }^{*}$ LaFrance (H. L.). Delicate silvery rose, changing to a silvery pink; very large, full, of fine globular form; a most constant bloomer; very sweet and cannot be surpassed in delicacy of color.

$\dagger$ LaReine (H.). Brilliant, glossy rose, very large; cupped and beautiful; a very hardy, useful rose.

Louis Van Houtte (H.) Crimson maroon; large, full and fragrant; a very free bloomer and one of the best crimson roses.

*Madame Alfred Carrier (H. N.). Color rich creamy white, faint $1 \mathrm{y}$ tinged with pale yellow; sweet and beautiful; a strong grower and free bloomer.

* Madame Plantier (H. C.). Pure white, above medium size, full; produces in great abundance early in the season; one of the best white roses; hardy; suitablc for cemetery planting.

* Magna Charta (H. C.) Bright pink, suffused with carmine; very large, full

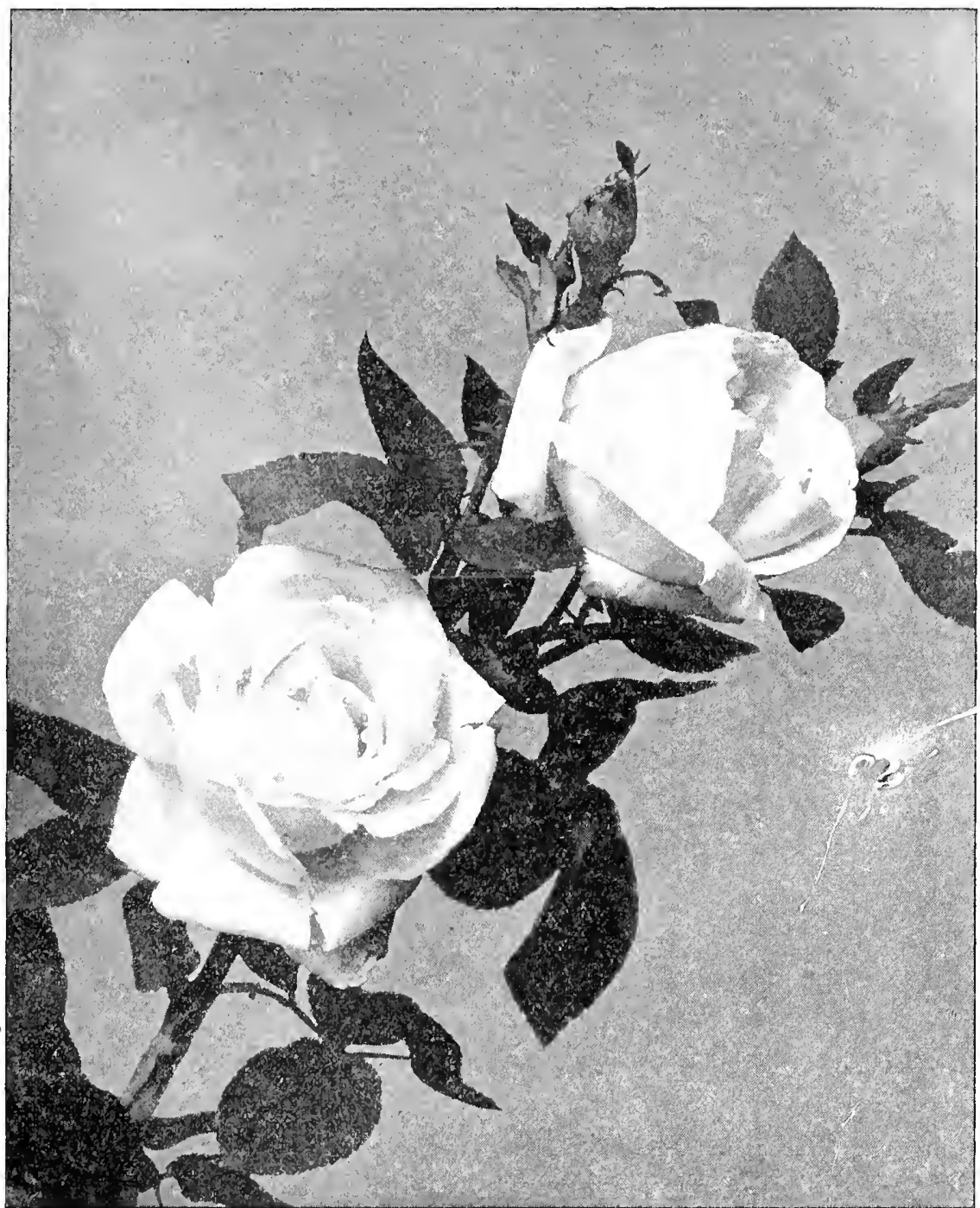

FRAU KARL DRUSCHKI-Snow Queen The Bcst Hardy White Rose

and fragrant, with magnificent foliage. A free bloomer.

Marchioness of Dufferin (H.). New. Vcry large and beautiful rosy pink, suffused with yellow at base of petals, which are relaxed; a vigorous grower.

Marchioness of Londonderry (H.). New. Flowers of great size, perfectly formed on stout stems. Color ivory white.

Marchioness of Lorne (H.). New. Color shaded with vivid carmine; large, full, cupped; buds long and handsome; remarkable for its perpctual habit.

Margaret Dickson (H.). Pure white, fine form, very large, a strong grower and a free bloomer. Flowers set in a whorl of leaves.

Mabel Morrison. White, sometimes tinged with blush; autumn the edges of the petals are often pink. In all save color and substance of petals, this variety is identical with Baroness Rothschild.

Madame Caroline Testout. Flowers large and double, color clear bright rose; very sweet, resembling La France, but of more sturdy habit; very free flowering.

Marshal P. Wilder (H.). Color cherry carmine, richly shaded with maroon, very fragrant and a free bloomer; a vigorous grower and hardy.
${ }^{*}$ Mrs. John Laing (H.) It is very free flowering, commencing to bloom early in the season and continues to bloom profusely until late autumn. Color a soft, delicate pink, with a satin tinge; very fragrant.

Madame Charles Wood (H.). The flower is extra large, full and double; color deep rosy crimson, sometimes brilliant scarlet with maroon shading.

Madame Gabriel Luizet (H.). A magnificent pink rose: very large and possesses a plensing fragrance.

Mrs. R. G. Sharman Crawford (H.), New. Deep rosy pink, outer petals pale flesh, base of petals cream; large and perfect form. A constant bloomer and vigorous grower.

*Paul Neyron (H.). This magnificent rose is by far the largest variety in cultivation; very double and full, of a beautiful dcep rose color, and delightfully fragrant.

Pierre Notting (H.). Deep crimson, shaded with velvet; globular in form; very large and full, and one of the finest dark roses.

Prince Camil'e de Rohan (H.). Deep velvety crimson, large, moderately full. One of the darkest in cuitivation, and a splendid rose. 


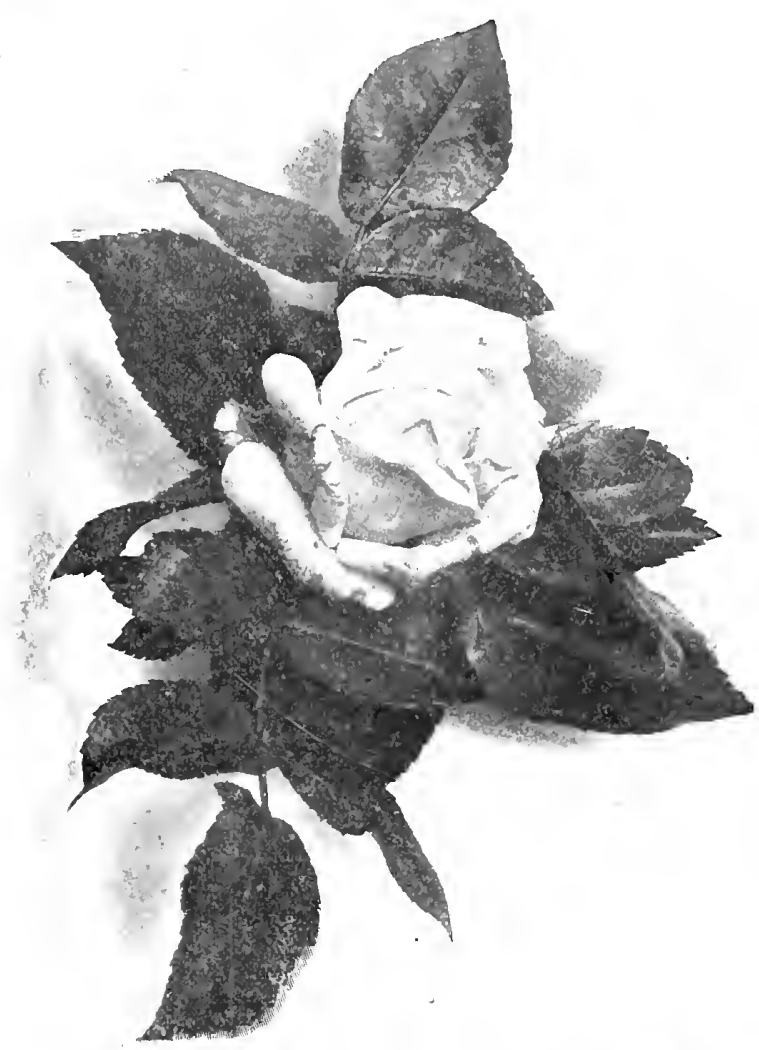

Margaret ${ }_{*}^{\square}$ ickson

Soliel d'Or (A unique Rose). Flowers are large, full and globular; color superb, varying from gold and orange-yellow to reddish-gold, shaded with nasturtium red.

*Ulrich Brunner (H.). A superb rose; a seedling from Paul Neyron; extra large, bold flowers; full and globular; petals large and of good substance; color, rich glowing cherry, elegantly lighted with scarlet; fragrant.

*Victor Verdier (H.). Fine, bright rose, shaded with carmine; very hardy and a fine bloomer; a splendid rose.

*Vick's Caprice (H.). Large, pink, striped and dashed with carmine and white; is a vigorous grower and a free bloomer.

White La France (Augustine Guinoisseau) ( $\mathrm{H}$. T.).This magnificent new rose is a pure white La France, having just a breath of rose-tinted blush; the buds and flowers are extra large, very full and finely formed. It is a free, continuous bloomer.

\section{Austrian Roses}

The roscs of this species are summer or spring bloomers, but they blossom so profusely and their rich golden yellow is so intense that they deserve a place in all collections; growth is favorable for a hardy shrub.

N. B. These roses bear on the terminals of a preceding ycar's growth and pruning must be done just after blossoming.

Harrison Yellow. A singlc variety, foliage pinnate, growth thorny, fine.

Persian Yellow. Deep bright yellow; s mal1 but handsome; double, a very early bloomer and a' fine hardy yellow rose; foliage bright and showy.

\section{Moss Roses}

This class of Roses is grown mostly for the beautiful mossy buds. They requirc close pruning and high culture.

*Blanche Moreau. Flowers pure white, large and full; buds very bcautiful. A rampant grower, being almost as vigorous as a climber.

Crested. Deep pink buds surrounded with mossy fringe and crest; very beautiful and fragrant; growth slender.

Henry Martin. Fine rosy red; large, full and globular; fragrant and mossy.

*Princess Adelaide. A vigorous grower, pale rose and of medium size and good form.

Perpetual White. Pure white and very mossy bud.

*Salet. A vigorous grower and perpetual bloomer. Light rose, large, full. The best of the class. A true perpetual moss, blooming at intervals from June to November.

William Lobb. Violet red; a strong grower.

\section{Hardy Climbing and Rambler Roses}

*Baltimore Belle (P.). Pale blush, nearly white, double. A strong grower, very hardy and the best of its class.

${ }^{*}$ Crimson Rambler (Japanese). The foliage is rich, dark green, the growth rapid, but its great beauty is when the plant is covered with a profusion of the brightest crimson flowers which remain on a long time.

*Dawson. Flowers in clusters, similar to the Rosa Multiflora. They are of a deep pink color and quite full; very fragrant.

*Dorothy Perkins. A splendid new climbing rose. The flowers are very double, of good size and are borne in

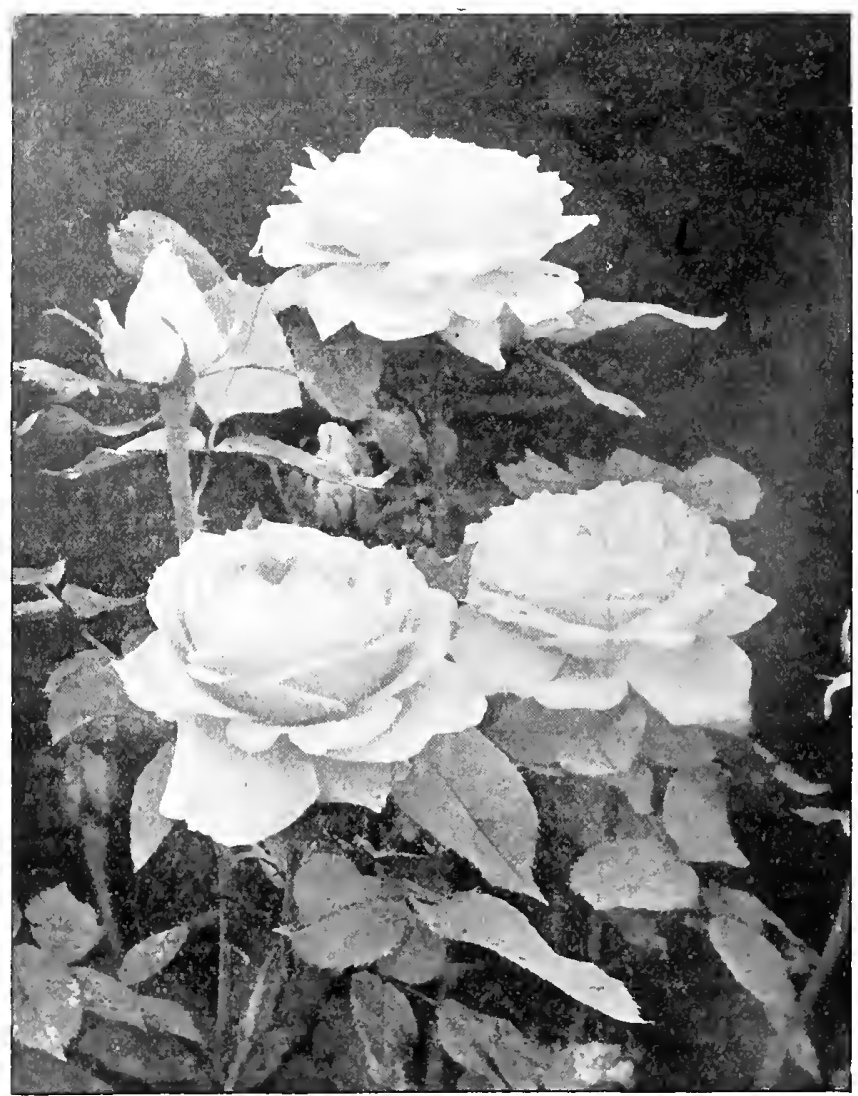

Madame Gabriel Luizet 


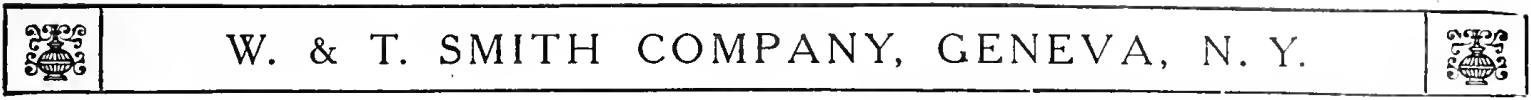

clusters of ten to twenty. Buds remarkably handsome; the eolor is a elear shell-pink and holds a long time without fading; very sweet scented.

${ }^{*}$ Gem of the Prairie (P.). Carmine crimson, occasionally blotched with white; at cross Hybrid between Madame Laffey and Queen of the Prairie.

${ }^{*}$ Greville or Seven Sisters (P.). Crimson, changes to blush; flowers in large clusters, not as hardy as others.

*Gardenia. Flowers bright vellow, and when open eream color, three to three and a half inches in diameter, delightfully fragrant, and produced freely.

Flower of Fairfield. The New Everblooming Crimson Rambler. Of the numerous recent introductions, this stands foremost as a Crimson-flowered Rambler, and the fact that it is a perpetual bloomer makes it excecdingly popular. The flowers are produced in marvelous profusion, are of a bright crimson color, more brilliant than the common Crimson Ramblcr.

Hiawatha. A new rambling variety of great beauty, bearing large trusses of single deep crimson flowers, shading to almost white in the center, with rich golden-yellow anthers.

Lady Gay. Habit and appcarance much like Dorothy Perkins but flowers are a deeper color and blooms later.

Multiflora Japonica. It is exceedingly free-blooming, and towards the end of June the plant is covered with great elusters of small white, single, sweetly fragrant flowers, in which the golden-colored anthers make charming contrast with the snowy-white petals.

*Pink Rambler (Euphrosyne). Possesses the same valuable features found in the White Rambler, with which it differs only in color of flower, which is a brilliant light carmine.

*Queen of the Prairie (P.). Bright rosy red, frequently striped with white; large, compact and globular.

*Philadelphia Rambler. An improvement on the famous Crimson Rambler, flowers being larger, much more double, and of a light crimson color.

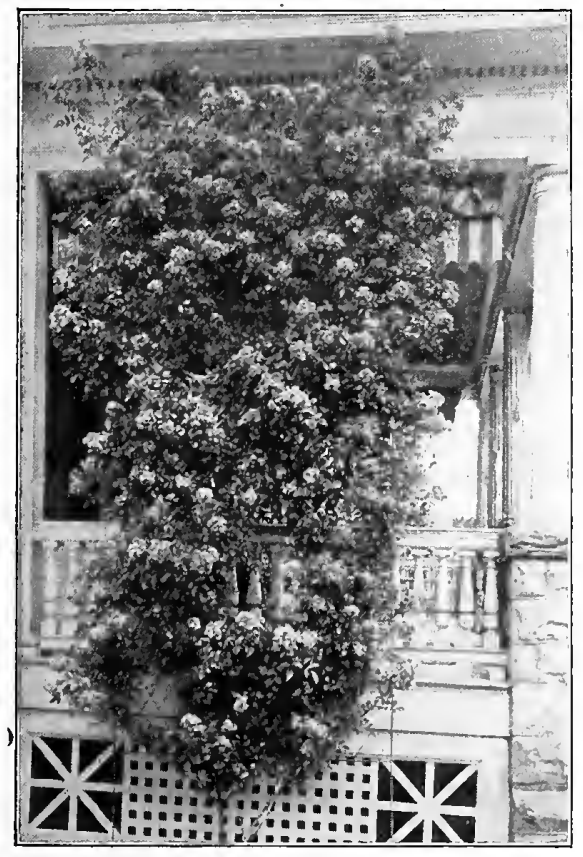

Flower of Fairfield

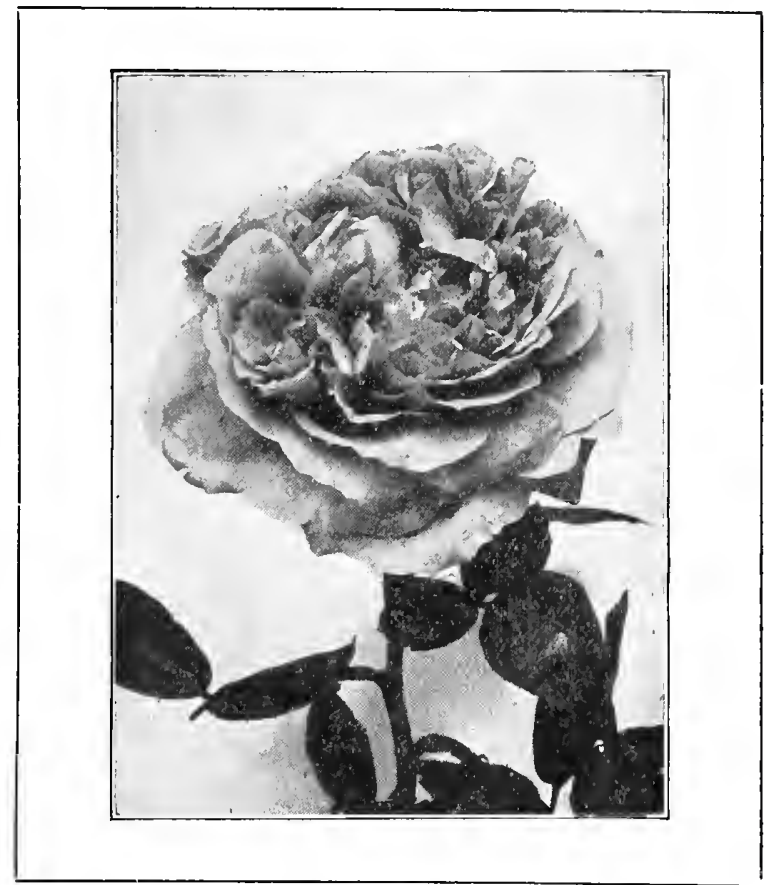

Paul Neyron

Tausendschon. A new and good forcing rose, no other rambler or climber can compare with it in color, which shades from a cream to saffron yellow.

Wedding Bells. An excellent climber similar to Lady Gay but it blooms earlier, flowers not quite so large, very deep pink, a strong grower.

*White Rambler (Thalia). Flowers are the size of a silver quarter, perfectly filled, very fragrant. Color pure white, sometimes tinged with blush. Blooms in clusters. Vigorous grower.

Veilchenblau (Violet blue). The showy, yellow stamens and blue flowers together give the whole a wonderful aspect.

*Yellow Rambler (Aglaia). A new, hardy climbing rose of the class and habit of the famous crimson rambler: flowers medium size, cup shape, nearly full, sweet scented.

\section{Rugosa Roses and Their Hybrids}

This very interesting group is of Japanese origin and possesses some wonderful characteristics. The plant is very ornamental having a rich plicated foliage. The flowers are mostly single.

*Agnes Emily Carman. Flowers in clusters: brilliant crimson, of the shade of General Jacqueminot; very free blooming, and continuing in bloom nearly all summer; a rampant grower, handsome foliage, and very hardy.

*New Century. Cross bctween cverblooming rose Clothilde Soupert and Rugosa Alba. Very hardy and a continuous bloomer. Color a bright rosy pink with bright red center. Petals bordered with a crcamy white.

Conrad Frederick Meyer. Clear silvery rose; very fragrant, vigorous but well formed like La France.

* Madam George Bruant. Buds long and pointed, semidouble when open, white and fragrant, borne in clusters through the season; vigorous and hardy.

Sir Thomas Lipton. A new double white rugosa.

*Rugosa Alba. Single, pure white, having five petals and highly scented.

Rugosa Rubra. Single, bright rosy crimson succeeded by large, brilliant berries of much beauty. 


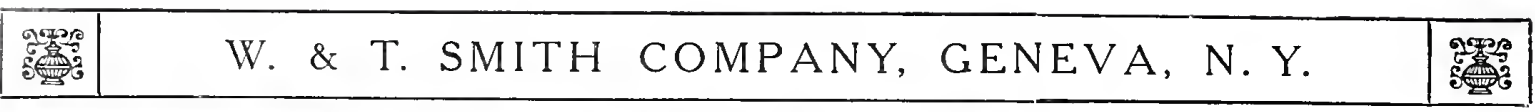

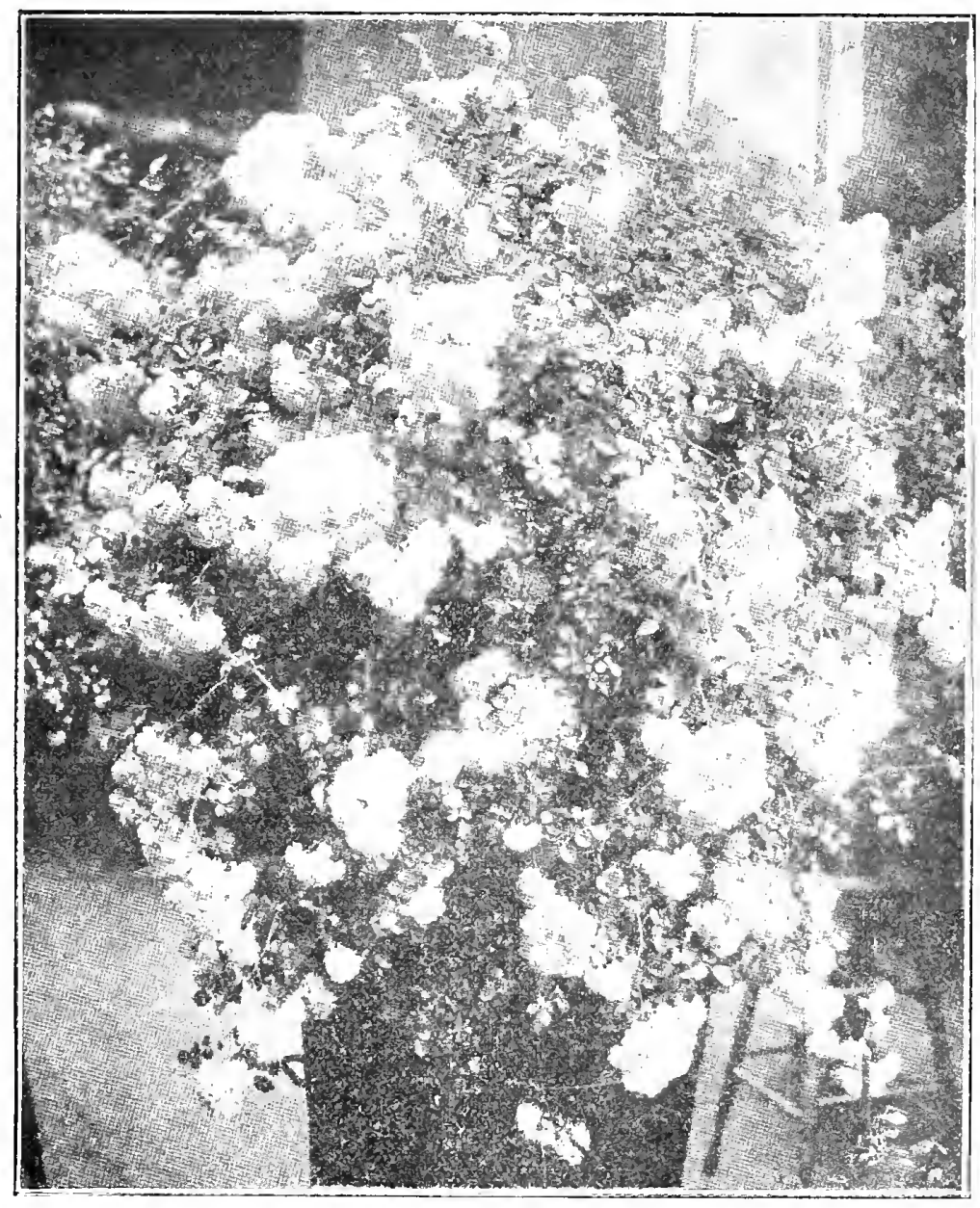

LAD GAY

\section{Sweet Briars}

LORD PENZANCE'S HYBRID SWEET BRIARS

*Amy Robsart. Lovely d eep rose.

*Anne of Geirestein. Dark crim. son.

*Flora Mclvor. Pure white blushed rose.

*Belle Poitevine. Deep rose color. Flowers semi-double.

* Meg Merrilies. Crimson.

*Rose Bradwardine. Beautiful clear rose.

\section{Wichuraiana or Memo- rial Rose}

A trailing species from Japan. The flowers appear in July and continue through the season and are very sweet. This is an excellent sort for cemetery planting or for covering embankments as it clings closely to the ground, thrives well in sun or shade.

*Manda's Triumph. Large double white flowers.

*Universal Favorite. L a rge double pink flowers.

*South Orange Perfection. Soft blush pink and a profuse bloomer.

*Pink Roamer. Single bright pink flowers with white center.

*Rose Wichuraiana. Showy clusters of white blossoms.

\section{Baby Ramblers}

Mad. Norbert Levavasseur. This new rose has been the sensation of Europe and America during the last year. It is practically a new "pocket edition" of the Crimson Rambler. Blooms every day the year round indoors, and all summer out-of-doors.

Anna Muller. In growth, similar to Baby Rambler. The flowers are brilliant rose and measure about 2 inches across. Semi-double. Blooms from June until frost.

Orleans. One of the most valuable of the Dwarf Polyantha section. The plant is vigorous, very free flowering, and the trusses are very large; color, geranium red suffused with rose. It flowers all summer.

Jessie. Dwarf Bedding Polyantha. Another charming novelty. Blooms constantly until killed by frost. Flowers disposed in huge clusters and of a bright cherry crimson color, which does not fade or develop the objectionable purple tints. It is by far the best conmon variety.

Catharine Zeimet. Dwarf White Baby Rambler, a very prolific bloomer. Flowers not so large as those of Novæ, but a much better bloomer.

Madam Cutbush. Pink Baby Rambler, very prolific bloomer, brilliant rose; flower about 1 inch across.

Novae. Anglaea. The new Dwarf White Rambler In habit of growth and blooming qualities it has all the characteristics of the famous Baby Rambler. The miniature flowers are produced in great numbers; are pure white and double.

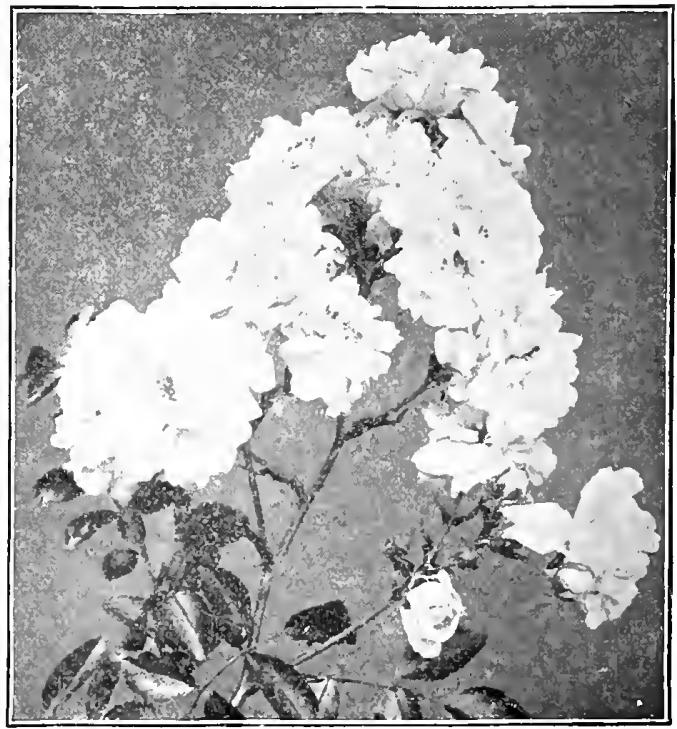

Dorothy Perkins 


\section{GENERAL INDEX}

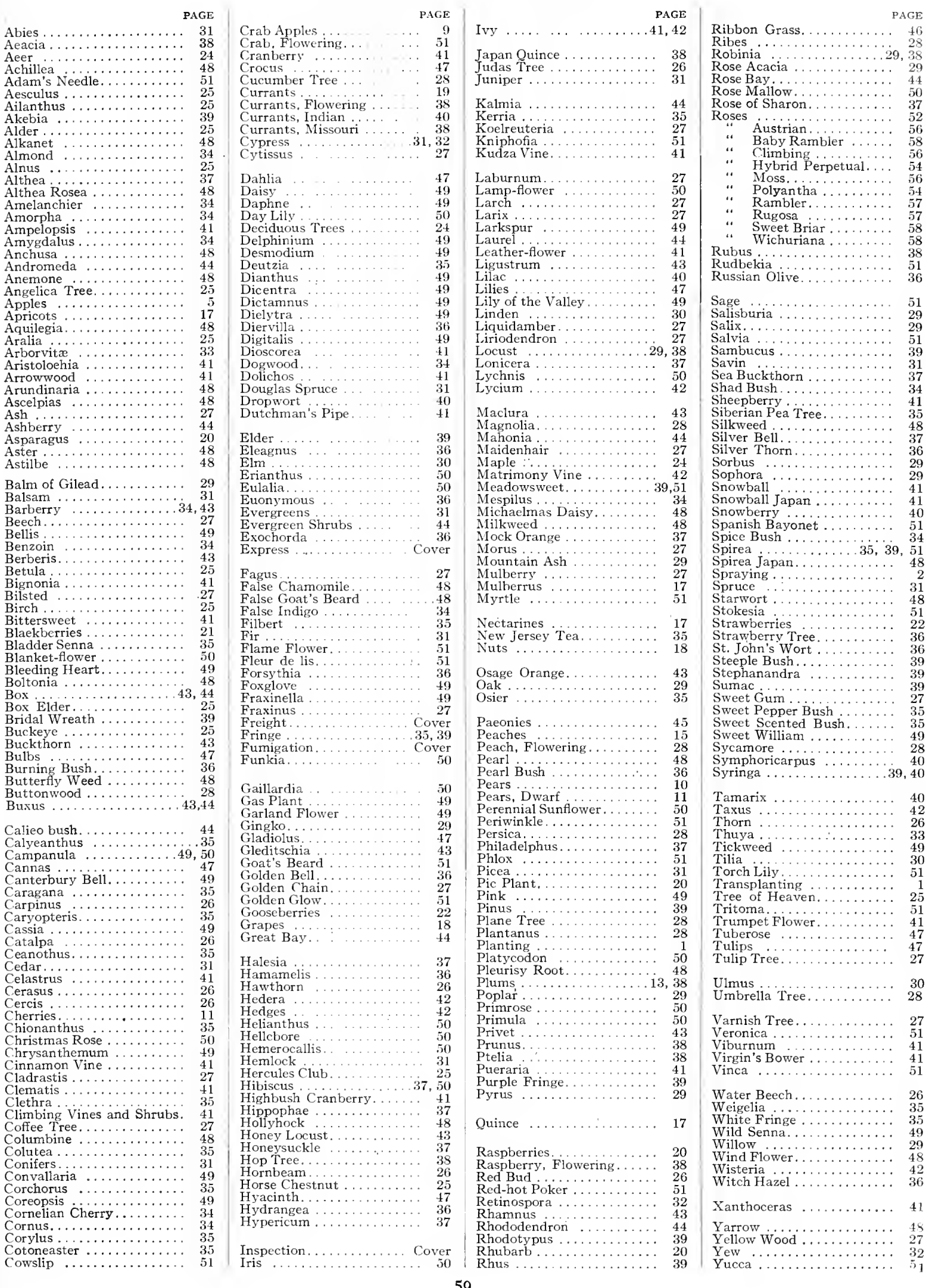




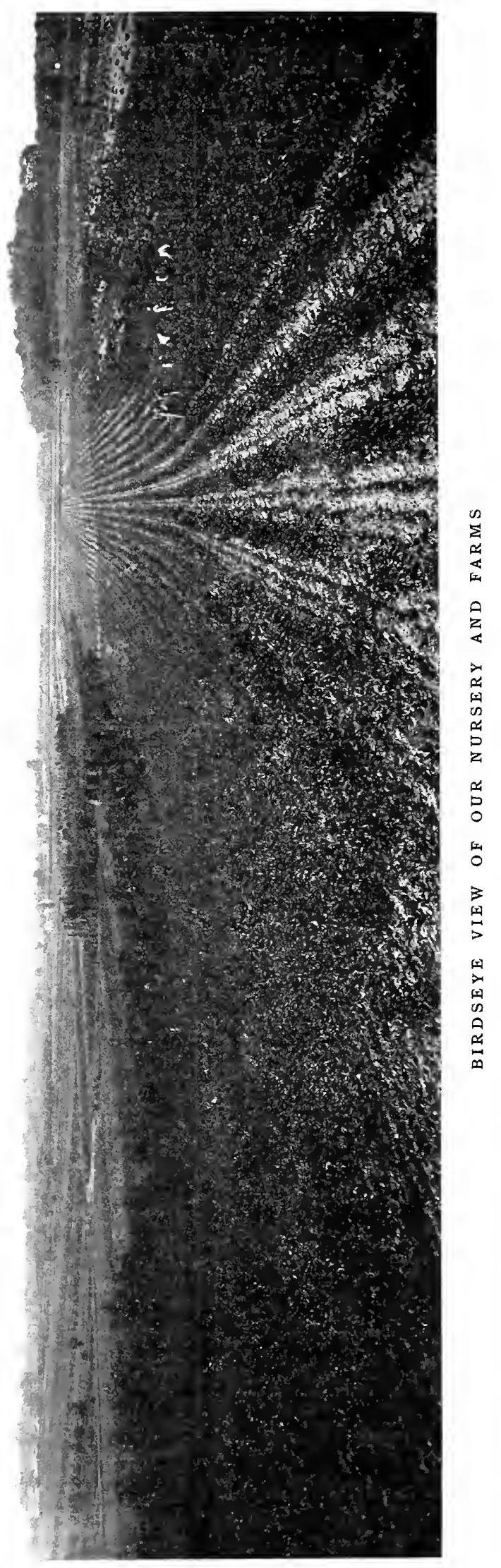




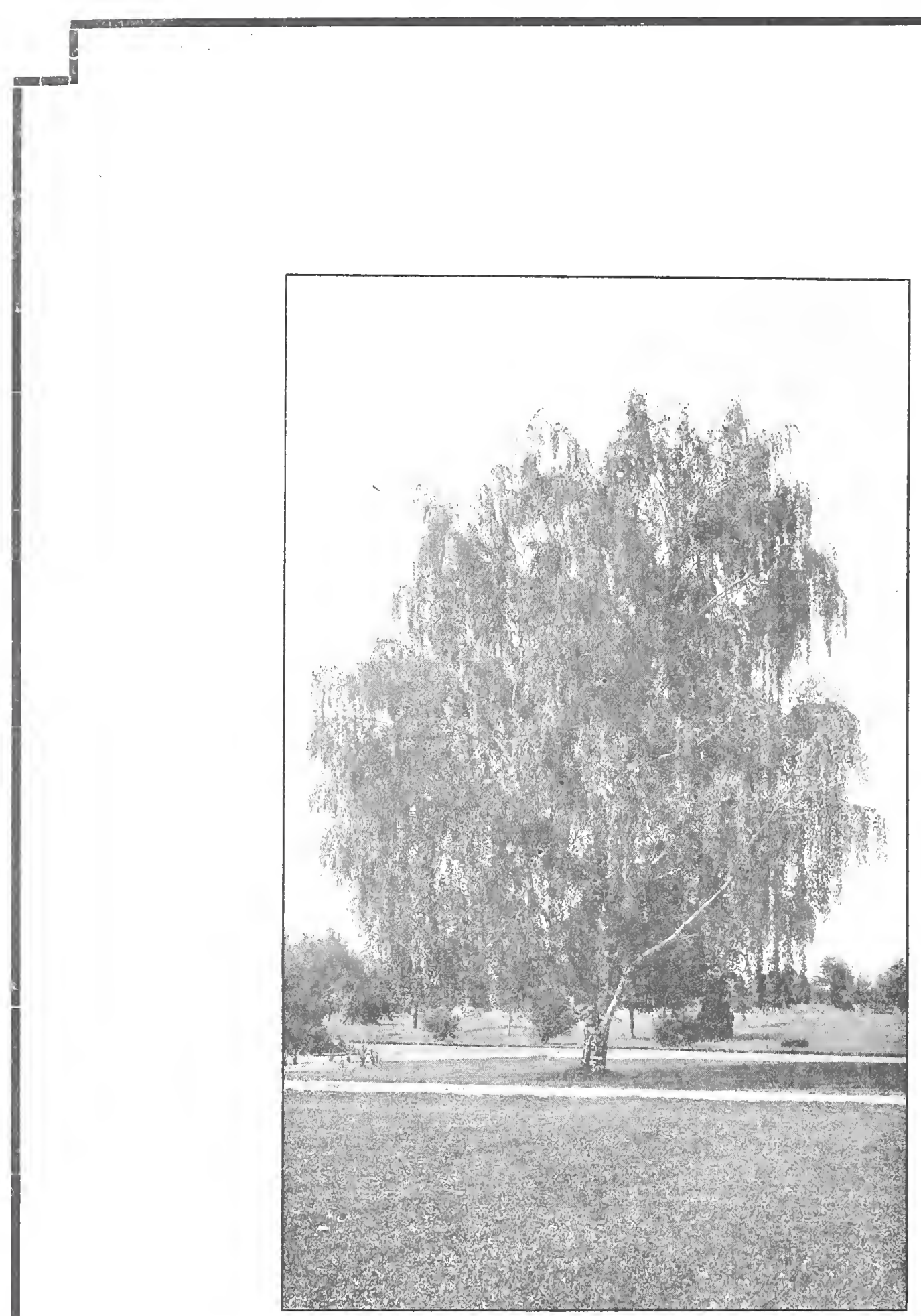

CUT LEAF WEEPING BIRCH 